CLAUDIA CAZAL

ESTUDO DA EXPRESSÃ O DOS GENES HOXB13 E HHEX EM

CARCINOMAS EPIDERMÓ IDES DE BOCA ATRAVÉ S DAS

TÉ CNICAS DE RT-PCR E HIBRIDIZAÇÃ O IN SITU

São Paulo

2004 


\section{Cláudia Cazal}

\section{Estudo da expressão dos genes HOXB13 e HHEX em carcinomas epidermóides de boca através das técnicas de RT-PCR e hibridização in situ}

\begin{abstract}
Tese apresentada à Faculdade de Odontologia da Universidade de São Paulo, para obtenção do título de Doutor pelo Programa de Pós-Graduação em Odontologia.
\end{abstract}

Área de Concentra ção: Patologia Bucal

Orientador: Prof. Dr. Fábio Daumas Nunes

Co-orientador. Prof. Dr. Marcelo Dớia Durazzo

\section{São Paulo}


Cataloga ção-na-Publica ção

Serviço de Documentação Odontol ógica

Faculdade de Odontologia da Universidade de São Paulo

Cazal, Cládia

Estudo da Expressão dos genes HOXB13 e HHEX em carcinomas epidermádes de boca através das técnicas de RT-PCR e hibridização in situ / Clá dia Cazal; orientador Fábio Daumas Nunes, co-orientador Marcelo Dória Durazzo. -- São Paulo, 2004.

123p. : fig., graf., $30 \mathrm{~cm}$.

Tese (Doutorado - Programa de Pós-Graduação em Odontologia. Área de Concentração: Patologia Bucal) -- Faculdade de Odontologia da Universidade de São Paulo. bucal

1. Carcinoma de céulas escamosas -Boca -Expressão gênica 2. Patologia

CDD 617.63

BLACK D65

AUTORIZO A REPRODU ÇÃO E DIVULGA ÇÃO TOTAL OU PARCIAL DESTE TRABALHO, POR QUALQUER MEIO CONVENCIONAL OU ELETR ÔIICO, PARA FINS DE ESTUDO E PESQUISA, DESDE QUE CITADA A FONTE E COMUNICADO AO AUTOR A REFER ÊNCIA DA CITA ÇÃO.

São Paulo, 01/11/2004

Assinatura:

E-mail: claudiacazal@yahoo.com.br 


\section{FOLHA DE APROVAÇÃO}

Cazal C. Estudo da expressão dos genes HOXB13 e HHEX em carcinomas epidermóides de boca através das técnicas de RT-PCR e Hibridização in situ [Tese de Doutorado]. São Paulo: Faculdade de Odontologia da USP; 2004.

São Paulo,

\section{Banca Examinadora}

1) $\operatorname{Prof}(\mathrm{a}) . \operatorname{Dr}(\mathrm{a})$.

Titulação:

Julgamento:

Assinatura:

2) $\operatorname{Prof}(\mathrm{a})$. $\operatorname{Dr}(\mathrm{a})$.

Titulação:

Julgamento:

Assinatura:

3) $\operatorname{Prof}(a) . \operatorname{Dr}(a)$.

Titulação:

Julgamento:

Assinatura:

4) $\operatorname{Prof}(a)$. $\operatorname{Dr}(a)$.

Titulação:

Julgamento:

Assinatura:

5) $\operatorname{Prof}(a) . \operatorname{Dr}(a)$.

Titulação:

Julgamento:

Assinatura: 


\section{A ldéia}

De onde ela vem?! De que matéria bruta

Vem essa luz que sobre as nebulosas

Cai de incógnitas criptas misteriosas

Como as estalactites duma gruta?!

Vem da psicogenética e alta luta

Do feixe de moléculas nervosas,

Que, em desintegrações maravilhosas,

Delibera, e depois, quer e executa!

Vem do encéfalo absconso que a constringe, Chega em seguida às cordas do laringe,

Tí sica, tênue, mí nima, raquí tica ...

Quebra a força centrí peta que a amarra, Mas, de repente, e quase morta, esbarra

No mulambo da língua parali tica.

Augusto dos Anjos

(1884 - 1914) 


\section{DEDICATÓ RIA}

A todos os pacientes vítimas de carcinoma epidermóide de boca, os quais contribuí ram fornecendo material bilológico para realização deste projeto.

Aos meus pais, Cláudio e Elizabete, e ao meu irmão, Cláudio, que me incentivaram sempre a dar mais um passo. A distância neste perí odo nos aproximou mais ainda.

Ao meu noivo, Cláudio, pelas palavras carinhosas, paciência e companheirismo. 


\section{AGRADECIMENTOS}

À minha famí lia pelo apoio incondicional.

À Famí lia Campos Sousa de Almeida (do lado Campos e do lado Almeida) pela recepção, carinho e casa com lareiras. Sem a ajuda de vocês esta etapa da minha vida teria sido de difí cil conclusão. Nenhuma forma de agradecimento escrita jamais poderá retribuir a amizade e confiança em mim depositada.

Ao Prof. Dr. Ney e Profa. Dra. Vera pela oportunidade de estar aqui nesta Instituição de Ensino e pelo exemplo de liderança. Para os Senhores existe a frase: "por trás de todo grande homem existe uma grande mulher'. Ou vice-versa... Obrigada por me permitir concluir esta etapa tão desejada da minha vida.

Ao Prof. Dr. Alberto R. Ferraz pela recepção em sua Disciplina e pela colaboração essencial para a realização deste trabalho.

Aos Residentes da Disciplina de Cirurgia de Cabeça e Pescoço e aos Professores e Assistentes do Serviço pela colaboração e apoio na fase clí nica deste trabalho.

À Profa. Dra. Ana Paula Veras Sobral por acreditar em meu potencial e estar sempre presente. Pelos conselhos profissionais e pelos momentos agradáveis de trocas de experiência. Ana, a intimidade é mesmo um caminho sem volta!

Aos Professores da Disciplina de Patologia Bucal da Faculdade de Odontologia de Pernambuco (FOP-UPE) pelo apoio, carinho, confiança e ensinamentos. Vocês serão sempre meus modelos de conduta. 
Fê, Thaisinha, Dori e Durazzo... Para vocês nada de protocolos. FOI MUITO BOM! Obrigada por tudo. E quando digo tudo, estou incluindo até os puxões de orelha, os sapatos e os terninhos cor-de-rosa, as discussões construtivas, as aulas de estatí stica, de conduta, de marketing etc., etc., etc.. Vocês serão minhas melhores lembranças.

Ao Prof. Dr. Durazzo. Doctóris, docére, doutor, doctor, douctor, dottor... Comprendere? Obrigada!

À Profa. Dra. Silvia Lourenço, pela paciência e acolhimento em seu laboratório. Conselhos, opiniões e contribuições indispensáveis para conclusão desta Tese.

Aos meus colegas de turma que ainda estão concluindo, aos que já nos deixaram (vocês fazem muita falta!) e aos que acabaram de chegar (boa sorte!).

Aos professores da FOUSP, em especial aos da Disciplina de Patologia Bucal por dividirem suas experiências, atenção incondicional, disponibilidade e orientação. Especialmente ao meu Orientador Prof. Dr. Fábio por abrir as portas do laboratório e me permitir aprender e indiretamente me ensinar o sentido da palavra perseverança. Diferenças não se perdoam, apenas são aceitas ou não. Desejo que vocês tenham aprendido algo com as nossas diferenças, assim como aprendi com as suas.

A todas as funcionárias, Zilda, Neia, Nair, Bia, Patní cia, Elisa, Edna, pelo apoio técnico-científico, pelos momentos engraçados e bate-papo... Vou sentir falta!

À Gracita Silva-Valenzuela. Quando eu crescer quero ser igual a você!

Ao meu irmão pelas aulas intermináveis de estat́ stica. Por tomar conta dos meus filhos que ficaram em casa.

A Cláudio Avellar pela paciência e palavras de conforto e sabedoria por telefone... Palavras literalmente caras... 
À FAPESP e à CAPES pelo auxílio à pesquisa e pela bolsa de Doutorado no Programa de Demanda Social. 
Cazal C. Estudo da expressão dos genes HOXB13 e HHEX em carcinomas epidermóides de boca através das técnicas de RT-PCR e Hibridização in situ [Tese de Doutorado]. São Paulo: Faculdade de Odontologia da USP; 2004.

\section{RESUMO}

O presente estudo teve o objetivo de verificar o padrão de expressão dos genes HOXB13 e HHEX em carcinomas epidermóides de boca (CEB) através das técnicas de Transcriptase Reversa em Reação de Cadeia Polimerase (RT- PCR) e Hibridização In situ (ISH). Fragmentos de tecido tumoral e de tecido não tumoral adjacente à lesão foram obtidos de 30 pacientes portadores de CEB no Serviço de Cirurgia de Cabeça e Pescoço do HC - FMUSP. As amostras tiveram seus cDNAs extraí dos e submetidos à amplificação por PCR. Os "amplicons" foram visualizados sob luz UV por eletroforese em gel de agarose a $1 \%$ contendo brometo de etí dio. A amplificação dos genes foram correlacionadas com a classificação UICC, TNM, graduação histológica, localização e espessura tumoral, invasão de tecidos adjacentes, perineural e vascular. Após seqüenciamento dos "amplicons" e confirmação dos genes foram confecionadas as sondas de mRNA para realização da técnica de hibridização in situ. Os resultados obtidos através da técnica de RTPCR mostraram que: a amplificação dos transcritos dos genes HOXB13 e HHEX podem ser detectados tanto no carcinoma epidermóide quanto no tecido não tumoral adjacente à lesão; não existindo diferença na amplificação dos transcritos de ambos genes para os dois grupos de tecido estudados; a amplificação do transcrito do gene HOXB13 mostrou relação estat́ stica com os fatores prognósticos: espessura tumoral, invasão perineural e invasão vascular; a amplificação do transcrito do gene HHEX mostrou relação estatí stica com os fatores prognósticos: invasão vascular, 
envolvimento com os tecidos adjacentes e uma relação inversa com a idade do paciente. A expressão dos transcritos dos genes HOXB13 e HHEX, detectados pela técnica de ISH, mostrou um padrão de marcação consistente e invariável para os tecidos analisados, estando expressos tanto em carcinoma epidermóide quanto no tecido não tumoral adjacentes à lesão. Os resultados apontam para uma correlação entre a expressão do HHEX e do HOXB13 e alguns fatores prognósticos importantes podendo representar um indicador prognóstico valoroso para o entendimento do comportamento biológico do CEB.

Palavras-Chave: Carcinoma epidermóide - Câncer de boca - RT-PCR Hibridização in situ - Homeobox, HOXB13, HHEX. 
Cazal C. HOXB13 and HHEX expression study in oral squamous cell carcinoma with the RT-PCR and in situ Hybridization techniques [Tese de Doutorado]. São Paulo: Faculdade de Odontologia da USP; 2004.

\section{ABSTRACT}

The aim of this study was to verify the HOXB13 and HHEX genes expression in oral squamous cell carcinoma (OSCC) using Reverse Transcriptase Polymerase Chain Reaction (RT-PCR) and in situ Hybridization techniques. Tumoral tissues and adjacent non-tumoral oral mucosa specimens were obtained from 30 patients with OSCC at the Head and Neck Surgery Service HC (FMUSP). The samples were cDNA extracted and submitted to the RT-PCR technique. The amplicons were visualized in electrophoresis on a $1 \%$ agarose gel with ethidium bromide. Genes expressions were correlated with UICC staging, TNM stage, tumor location, tumor thickness, adjacent tissues involvement, vascular and perineural invasion, and cellular differentiation. Finally, direct sequence analysis was performed on PCR products to confirm cDNA sequence. Riboprobes were confectioned for in situ hybridization analysis. RT-PCR results showed HOXB13 and HHEX transcripts in both tumoral and non-tumoral tissue samples; no statistical correlation was verified between HOXB13/HHEX expressions and tumoral or non-tumoral tissues; there was a positive correlation between HOXB13 tumoral expression and tumor thickness, neural invasion, and vascular invasion; there was a positive correlation between HHEX tumoral expression and adjacent tissue involvement, vascular invasion, and a inverse relationship with patients age; ISH technique exhibited a consistent and invariable pattern of expression for both genes on both tumoral and non-tumoral tissue samples. Present results points out to a correlation between HOXB13 and 
HHEX expressions, and some important prognostic indicators, and this may represent a valuable tool to understand the biological behavior of OSCC.

Key-works: Squamous cell carcinoma - Oral cancer - Homeobox, HHEX, HOXB13 RT-PCR - In Situ Hybridization. 


\section{LISTA DE ILUSTRAÇÕES}

P.

Figura 2.1 Distribuição dos genes HOX no genoma humano. O "cluter" $A, B$, C e D estão localizados respectivamente nos cromossomos 7,17 , 12 e 2

Figura 2.2 Localização do gene HOXB13 no cromossomo 17 humano 32

Figura 2.3 Expressão de genes Homeobox de maneira colinear em Drosophila melanogaster e embrião de camundongo

Figura 2.4 Localização do gene HHEX no cromossomo 10 humano

Figura 4.1 Exemplo de resultado obtido com gel de integridade de RNA mostrando duas bandas $28 \mathrm{~S}$ e $18 \mathrm{~S}$. PP - marcador de pares de base

Figura 4.2 Exemplo da amplificação do mRNA da $\beta$-actina nos casos de CEB e tecidos não tumorais adjacentes à lesão (casos de 1 a 9) confirmando a reatividade dos tecidos. Legenda: $\mathrm{pb}=$ pares de base, $\mathrm{N}=$ normal, $\mathrm{T}=$ tumor

Figura 4.3 Imagem fotográfica do resultado obtido após linearização do vetor contendo a seqüência de cDNA dos genes HOXB13, HHEX e da $\beta$-actina, da esquerda para direita

Figura 4.4 Imagem fotográfica do resultado obtido após transcrição das sondas do HOXB13 anti-senso (1) e senso (2) e HHEX anti-senso (3) e senso (4) respectivamente

Figura 5.1 Gel de agarose 1\% mostrando amplificação dos transcritos do gene HOXB13 por RT-PCR nos casos de carcinoma epidermóide (TT) e tecido não tumoral (NT) 
Figura 5.2 Gel de agarose 1\% mostrando amplificação dos transcritos do gene HHEX por RT-PCR nos casos de carcinoma epidermóide (TT) e tecido não tumoral (NT)

Figura 5.3 Fotomicrografias ilustrando padrão de expressão do gene HOXB13 em carcinoma epidermóide de boca.................................

Figura 5.4 Fotomicrografias ilustrando padrão de expressão do gene HHEX em carcinoma epidermóide de boca..................................................

Figura 5.5 Microfotografias ilustrando o padrão de expressão dos transcritos dos genes HOXB13 (de A a F) e HHEX (de G a L) em NT.

Figura 5.6 Fotomicrografias de cortes submetidos à técnica de ISH com a sonda senso como controle negativo para os genes HOXB13 (Figuras A, C e E) e HHEX (Figura G) 


\section{LISTA DE QUADROS}

Quadro 4.1 - Caracteŕ sticas clí nicas e histopatológicas dos pacientes, classificação UICC e pTNM

Quadro 4.2 - Seqüência dos iniciadores dos genes HOXB13, HHEX e $\beta$-actina ......54

Quadro 4.3 - Endonuclease de restrição e enzimas de transcrição utilizadas 59

Quadro 5.1 - Relação estatí stica entre a presença do transcrito do gene HOXB13 nos TT e os fatores prognósticos clí nicos .........................................70

Quadro 5.2 - Relação estat́ stica entre a presença do transcrito do gene HHEX nos TT e os fatores prognósticos clí nicos 


\section{LISTA DE GRÁ FICOS}

Gráfico 5.1 - Distribuição da incidência de CEB segundo sexo e década de vida....65

Gráfico 5.2 - Distibuição de CEB segundo o grupo étnico (NC = Não consta) ......66

Gráfico 5.3 - Distribução de CEB segundo a localização ...................................66

Gráfico 5.4 - Distribuição de CEB segundo classificação UICC ...........................67 


\section{LISTA DE ABREVIATURA E SIGLAS}

AJCC Do inglês American Joint Committee on Cancer = Associação do Comitê Americano de câncer

BCIP 5-bromo-4chloro-3indoyl-phosphate, compõe parte do cromógeno da técnica de hibridização in situ junto com o NBT

BMPs Abreviação para referência do gene proteí na morfogenética óssea

cDNA DNA complementar

CD5+ Molécula de superfí cie de linfócitos T para reconhecer antí genos

CD19+ Molécula de superfí cie de linfócitos T para reconhecer antí genos

CEB Carcinoma epidermóide de boca

CEC Carcinoma Espinocelular ou carcinoma epidermóide

DEPC Dietil-pirocarbonato

dNTP Deoxinucleot́ deos trifosfato

Da Daltons

Dpc Dias pós-coito

DTT Ditiotreitol

EDTA Ácido etilenodiaminotetracético

elF4E Abreviação para o gene do Fator 4E de Iniciação de Tradução

EKLF Fator de transcrição eritróide

FAPESP Fundação de Amparo à Pesquisa do Estado de São Paulo

FGFs Abreviação para referência do gene fator de crescimento fibroblástico 


\begin{tabular}{|c|c|}
\hline Fase S & Referente fase de Sintese de DNA do ciclo celular \\
\hline Fkl-1 & Receptor para o fator de crescimento endotelial (VEGF) \\
\hline GATA 1 & Tipo de fator de transcrição eritróide \\
\hline Y-catenina & Gamma-catenina, um oncogene \\
\hline HCFMUSP & $\begin{array}{l}\text { Hospital das Cll nicas da Faculdade e Medicina da Universidade de São } \\
\text { Paulo }\end{array}$ \\
\hline $\mathrm{Hpc}$ & Horas pós-coito \\
\hline IGF-1 & Proté na para ligação de RNAm em outra estrutura \\
\hline $\lg G$ & Imunoglobulina G \\
\hline ISH & Do inglês "In situ Hybridization" = Hibridização in situ \\
\hline $\mathrm{Kb}$ & Kilobases \\
\hline $\mathrm{KDa}$ & Kilodaltons \\
\hline LBAgar & Meio de Cultura de Luria e Bertani + Agar \\
\hline LB Broth & Meio de Cultura de Luria e Bertani \\
\hline MDM2 & $\begin{array}{l}\text { Abreviação para gene humano homólogo ao gene "doble minute-2" em } \\
\text { camundongos }\end{array}$ \\
\hline $\mathrm{MgCl} 2$ & Cloreto de Magnésio \\
\hline$\mu g$ & Microgramas \\
\hline Min & Minutos \\
\hline $\mathrm{ml}$ & Mililitros \\
\hline$\mu \mathrm{l}$ & Microlitros \\
\hline $\mathrm{mm}$ & Milí metro \\
\hline $\mathrm{mM}$ & Milimolar \\
\hline mRNA & RNA mensageiro \\
\hline $\mathrm{NaCl}$ & Cloreto de sódio \\
\hline NBT & 4-nitroblue tetrazolium chloride \\
\hline
\end{tabular}


N-CAN Molécula de adesão neural

Nocaute $^{-/-} \quad$ Do português $=$ Knockout $^{-/}$. Animais mutantes com perda homozigótica para determinado gene

Nocaute $^{+/-}$Do português $=$Knockout $^{+/-}$. Animais mutantes com perda heterozigótica para determinado gene

NT Tecido não tumoral adjacente à lesão

NTMT $\quad \mathrm{NaCl}+$ Tris $+\mathrm{MgCl} 2+$ Tween

OCT Polí mero inerte utilizado para emblocar tecido fresco em criomolde.

OD Do inglês Optical Density = densidade óptica medida através de espectrofotômetro

ONSA Do Inglês Organization For Nucleotide Sequence and Analysis = Organizção para sequenciamento e análise de nucleotí deos

PBS Phosphate Buffered Saline

PBT PBS + Tween $10 \%$

PCR Do ingles "Polimerase Chain Reaction" = Reação de Polimerase em cadeia

PGCCP Projeto Genoma do Câncer de Cabeça e Pescoço

pH Potencial hidrogeniônico

PPARgamma Do inglês: peroximome proliferators activated receptor gamma

p53 Gene supressor de tumor

p21 Gene tradutor da proteína de $21 \mathrm{KDa}$ também chamado actin-related protein $2 / 3$ complex subunit 3

$\mathrm{Rb} \quad$ Gene envolvido o processo de desenvolvimento do retinoblastoma

RNase Ribonuclease, enzima de degradação de RNA

Rpm Rotações por minutos

RT-PCR Do inglês "Reverse Transcriptase Chain Reaction" = Transcrição Reversa com Reação de Polimerase em Cadeia 
Runx-1 Tipo de fator de transcrição para hemangioblasto

Scl Tipo de fator de transcrição para hemangioblasto

SDS Sodium Dodecyl Sulfate

Shh Abreviação para referência do gene Sonic hedgehog

SSC Saline (or salt) sodium citrate, solução tampão fraca usaa com inos sódio como meio isotônico para o controle da concentração de $\mathrm{Na}^{+}$

TA Temperatura Ambiente

TAE Tris-acetato + EDTA

TBST Tris-buffered saline + Tween 20

TE Tris + EDTA

TNM Sistema internacionalmente utilizado para descrição de tumores sólidos onde $\mathrm{T}=$ tumor, $\mathrm{N}=$ Nódulo e $\mathrm{M}=$ Metástase

Tris-HCL Tampão Tris + ácido cloń drico

TT Tecido tumoral

TTAT (TAAT e TTAC) Tipos de sítios de transcrição localizados nas regiões flanqueadoras dos genes

UICC Do francês Union Internationale Contre le Cancer = União Internacional do Controle de Câncer

UV Ultravioleta 


\section{LISTA DE Ś MBOLOS}

$\begin{array}{ll}{ }^{\circ} \mathrm{C} & \text { graus Celsius } \\ \beta & \text { Beta } \\ \alpha & \text { Alfa. Referente à sonda anti-senso } \\ \mathrm{S} & \text { Referente à sonda senso } \\ & \\ \circledR & \text { Marca registrada }\end{array}$




\section{SUMÁ RIO}

p.

1 INTRODUÇÃ O

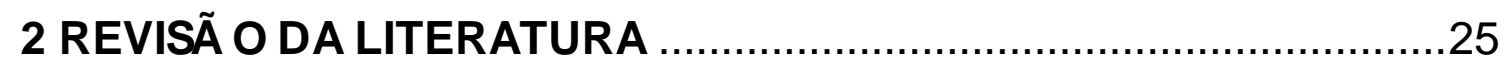

2.10 câncer de boca no Brasil ............................................................... 25

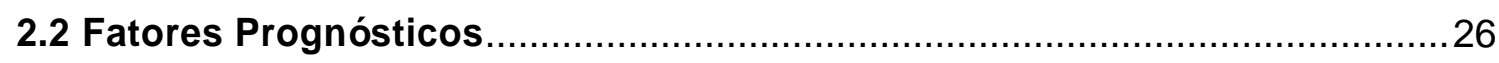

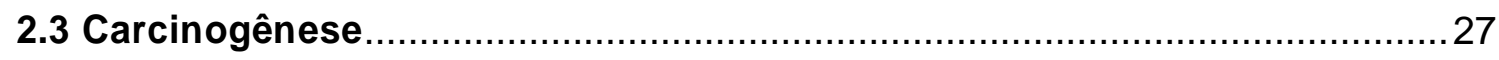

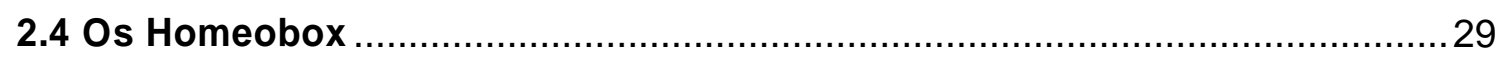

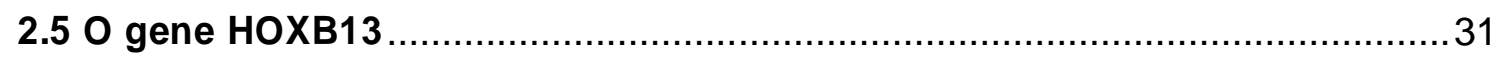

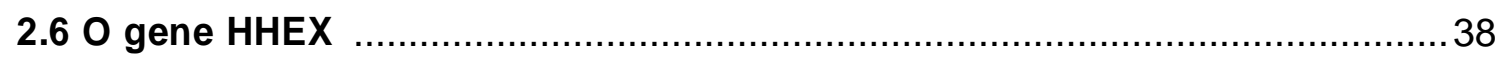

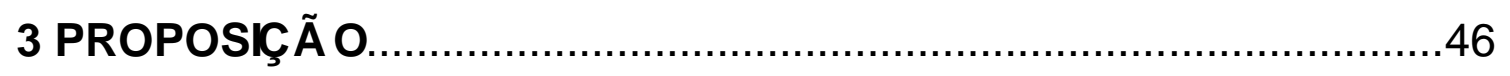

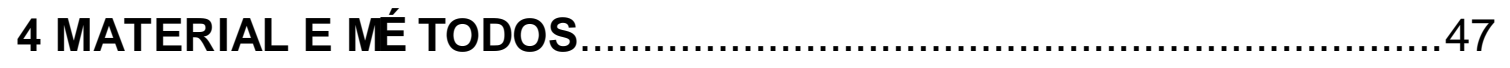

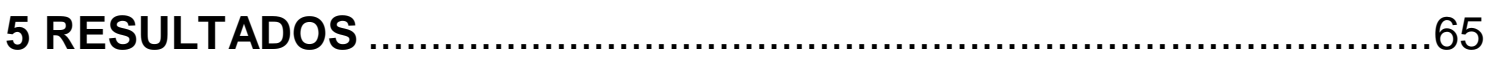

6 DISCUSSÃ O

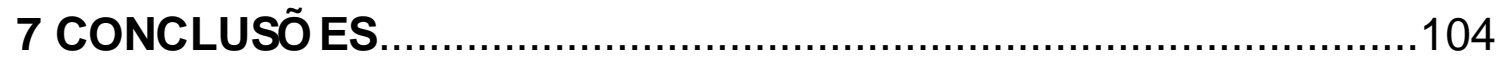

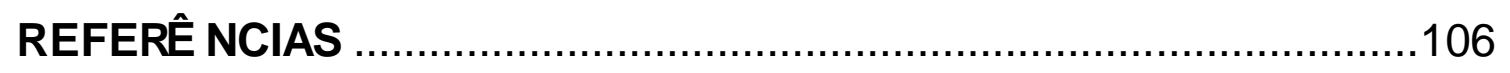

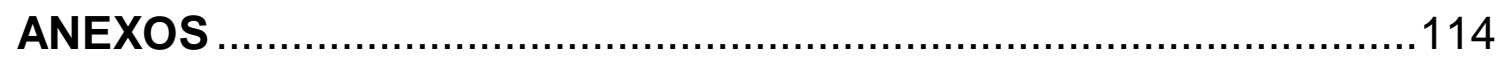




\section{INTRODUÇÃ O}

Em 1990 o Projeto Genoma Humano, um grande empreendimento mundial, iniciou o seqüenciamento de cerca de 80 mil genes das células do corpo humano. Desde então, as ciências biológicas vivem uma corrida na descoberta de informações para interpretar a complexa função da genética humana sobre os padrões de hereditariedade e das mutações nas várias enfermidades.

No Brasil, o surgimento de programas de seqüenciamento de genomas nasceu a partir do seqüenciamento da Xylella fastidiosa com a participação essencial de instituições como a Fundação de Amparo à Pesquisa do Estado de São Paulo (FAPESP) e a Organisation for Nucleotide Sequence and Analysis (ONSA). Desde então, os programas de seqüenciamento têm ocupado lugar de destaque no seqüenciamento de vários cânceres humanos como, por exemplo, o Projeto Genoma do Câncer de Cabeça e Pescoço (PGCCP) sob coordenação do Instituto Ludwig de Pesquisa do Câncer de São Paulo (NETO, 2001).

Baseado num consenso de que existe uma relação entre o desenvolvimento e a diferenciação celular, os genes de desenvolvimento se tornaram alvo de estudo de grandes centros de pesquisa buscando explorar a relação entre a embriogênese e a carcinogênese. Sua super-expressão e sua inibição têm sido relacionadas com vários cânceres em humanos.

Entre um "pool' de genes, o PGCCP identificou a presença dos genes Homeobox no câncer de cabeça e pescoço, os quais foram selecionados como linha 
de pesquisa do Laboratório de Patologia Molecular da Disciplina de Patologia Bucal da Faculdade de Odontologia da Universidade de São Paulo.

Os genes Homeobox são genes reguladores do desenvolvimento inicialmente identificados na década de 70, tendo a Drosophila melanogaster como seu principal modelo de estudo (LEWIS, 1978) e, posteriormente, identificados em organismos vertebrados superiores (ACAMPORA et al., 1989; STAIN et al., 1996).

Os genes Homeobox em vertebrados estão divididos em dois grandes grupos: os Hox e os não Hox. Os Hox, (ou agrupados) são cerca de 39 genes organizados em quatro grupamentos (clusters): A, B, C e D. Os não Hox (ou não agrupados) são constituí dos de inúmeros genes classificados, ou não, em pequenas famílias (ABATE-SHEN, 2002).

Assim, como parte de um projeto maior, o gene Homeobox agrupado HOXB13 e o não agrupado HHEX são o objeto de estudo desta pesquisa, a qual se propôs estudar o padrão de expressão destes genes em carcinoma epidermóides de boca (CEB) e sua eventual relação com o prognóstico dos pacientes portadores desta neoplasia. 


\section{REVISÃ O DA LITERATURA}

\subsection{O câncer de boca no Brasil}

Para o ano de 2003, o Instituto Nacional do Câncer (INCA, 2004) estimou cerca de 305.000 novos casos de câncer no paí s. Assim, torna-se a segunda causa de morte por doença com potencial risco de provocar aproximadamente 117.000 óbitos anuais.

O câncer de boca no Brasil ocupa lugar entre as principais neoplasias malignas e é responsável por alta morbidade tanto entre homens quanto em mulheres. O carcinoma epidermóide é a neoplasia maligna que mais acomete a cavidade bucal sendo o sexto mais freqüente em homens e o oitavo em mulheres após a quinta década de vida (ARAÚUO et al., 1998; DIB et al., 1990; DURAZZO; SILVA-FILHO, 1997; TAVARES; NOMA, 1997). Na Região Sudeste, foram previstos 267.980 novos casos de câncer para 2004, e destes 7.080 eram esperados ocorrer em cavidade bucal, constituindo o $8^{\circ}$ câncer em incidência no Brasil (ARAÚUO FILHO et al., 1998; DURAZZO et al., 2001). 


\subsection{Fatores prognósticos}

Dois sistemas internacionais, o da AJCC - American Joint Committee on Câncer (1998) e da UICC TNM - Union Internationale Contre le Câncer (1992), são parâmetros internacionalmente empregados para o relato e descrição do câncer, avaliação prognóstica, formulação de tratamento e comparação dos resultados obtidos nos pacientes tratados (YUEN et al., 2000).

O parâmetro T do sistema TNM é amplamente utilizado por profissionais da saúde no mundo todo na descrição de tumores sólidos. Entretanto, sendo o tumor uma estrutura sólida tridimencional, cada face pode possuir grupos de células com diferentes fenótipos (LOEB, 2001; LOEB; LOEB, 2000), com diferentes capacidades de invasão e comportamentos que, somando-se às áreas de necrose, nunca alcança uma forma esférica. O parâmetro $T$ tem, portanto, limitações que the são impostas pela variedade de fatores que determinam a forma e o tamanho dos tumores sólidos.

Assim, outras medidas passaram a ser consideradas como parâmetros prognósticos. Em câncer de mama, por exemplo, a idade, o tamanho do tumor, a gradação histológica e o parâmetro $\mathrm{N}$ já estão bem estabelecidos (FITZGIBBONS et al., 1999; MA et al., 2004).

A espessura tumoral já demonstrou ser um importante marcador prognóstico em melanomas cutâneos, câncer de colon, gástrico, de pulmão e de cabeça e pescoço (YUEN et al., 2000). Com relação ao câncer de boca o estadio N, a necessidade de esvaziamento cervical, margens cirúrgicas comprometidas e a espessura são fatores prognósticos bem estabelecidos na literatura e utilizados nos serviços cirúrgicos de cabeça e pescoço norteando a indicação de tratamento, a 
dose de radioterapia, de quimioterapia e agressividade da cirurgia oncológica (GONSALEZ-MOLES et al., 2002; KOKEMUELLER et al., 2002; MISHRA et al., 1999; SUTTON et al., 2003).

\subsection{Carcinogênese}

O câncer é uma doença crônica e degenerativa de etiologia multifatorial onde alguns fatores ambientais, como os raios UV e o consumo de tabaco e álcool, têm suas capacidades carcinogênicas comprovadas. Entretanto, muitos fatores genéticos e epigenéticos estão envolvidos no processo de forma complexa e dinâmica. Os mecanismos gênicos do carcinoma epidermóide de boca têm sido estudados na tentativa de explicar como ocorrem e de esclarecer sua evolução e resposta à terapêutica. Alguns achados moleculares se destacaram, como a participação da proteí na p53, do oncogene H-ras, da proté na p16, dentre outros, que possibilitaram avançar no conhecimento sobre a carcinogênese, mas que foram insuficientes para elucidar seus mecanismos. Não obstante os vários estudos desenvolvidos, não se pôde ainda estabelecer um marcador prognóstico em nível molecular (MIGNOGNA et al., 2002; PAPE, 1998).

Considerando a complexidade dos eventos envolvidos no ciclo celular metabolismo do DNA, mitose, segregação de cromossomos - percebe-se que muitos genes importantes podem estar envolvidos neste processo trabalhando em um complexo mecanismo de interação. Podemos apontar genes como, p53, p21 (vigilantes da integridade do genoma, envolvido na regulação da apoptose e 
recombinação gênica), a família do gene bcl-2 (reguladores da apoptose), p16 (" mitosis checkpoint") (BRAAKHUIS; LEEMANS; BRAKENHOFF, 2004).

Uma cascata de eventos que ativam em cadeia sinais bioquí micos resultam na ativação ou repressão de diversos genes coordenadores do ciclo celular, divisão e diferenciação através de fatores de crescimentos e seus receptores, citocinas, fatores de transcrição e enzimas de controle de replicação de DNA (LOURO, 2002).

Ainda é sugerido um possí vel fator complicador no câncer referido como fenótipo mutador, resultado do acúmulo de um grande número de alterações nas células somáticas. Estas mutações ocorrem aleatoriamente no genoma e, entre elas, estão as mutações nos genes responsáveis pela manutenção da estabilidade do genoma e da garantia de que estes serão devidamente transmitidos durante o processo de divisão celular (LOEB, 2001; LOEB; LOEB, 2000).

A despeito dos esforços e altos investimentos na busca de marcadores biológicos (BRAAKHUIS; LEEMANS; BRAKENHOFF, 2004; LOURO, 2002) há muito a ser descoberto. O que se tem de concreto e de fácil acesso a clínicos e pesquisadores para sugerir prognósticos em oncologia de cabeça e pescoço são os aspectos clí nicos e histopatológicos das lesões. Portanto, o conhecimento da doença (macro e microscópica), com suas diversas apresentações clí nicas e suas conseqüentes implicações do seu curso é essencial para os profissionais de saúde que se dedicam à prevenção, detecção precoce e tratamento do câncer de cabeça e pescoço, em especial do CEB (YUEN et al., 2000). 


\subsection{Os Homeobox}

Recentemente uma nova classe de genes despertou o interesse dos pesquisadores: os Homeobox. Estes genes foram primeiramente verificados na mosca Drosophila melanogaster e parecem ser os principais genes na regulação da morfogênese e diferenciação celular em animais (LEWIS, 1978; MARK; RIJLI; CKAMBON, 1997). O termo Homeobox surgiu de uma terminologia genética anteriormente chamada "mutação homeótica", mutação esta que envolvia a conversão de um seguimento corporal em outro membro (BRIDGE; MORGAN, 1923).

Como o desenvolvimento (morfogênese e diferenciação celular) e a carcinogênese possuem em comum uma relação no "controle" dos processos de proliferação e diferenciação celular, os Homeobox se tornaram alvo de pesquisas na busca da compreensão do câncer (NUNES et al., 2003).

Os Homeobox compreendem uma famí lia de genes que codificam proteí nas que controlam o processo de desenvolvimento do embrião e, além disso, estão envolvidos com a cascata de outros "master genes" como o Shh (Sonic hedgehog), FGFs (fator de crescimento fibroblástico) e BMPs (proteí na morfogenética óssea) entre outras (CHANG et al., 1998; FORD, 1998).

A famí lia dos genes Homeobox está dividida em 2 grupos: os Hox, agrupados ou classe 1 (Figura 2.1); e os não Hox, não agrupados ou divergentes. Os genes Hox compreendem nove a 11 genes organizados em seqüências homólogas e distribuí dos em quatro diferentes cromossomos (SCOTT, 1992). Começam a se 
expressar durante a gastrulação em mamí feros e controlam a morfogênese de várias regiões do embrião em desenvolvimento.

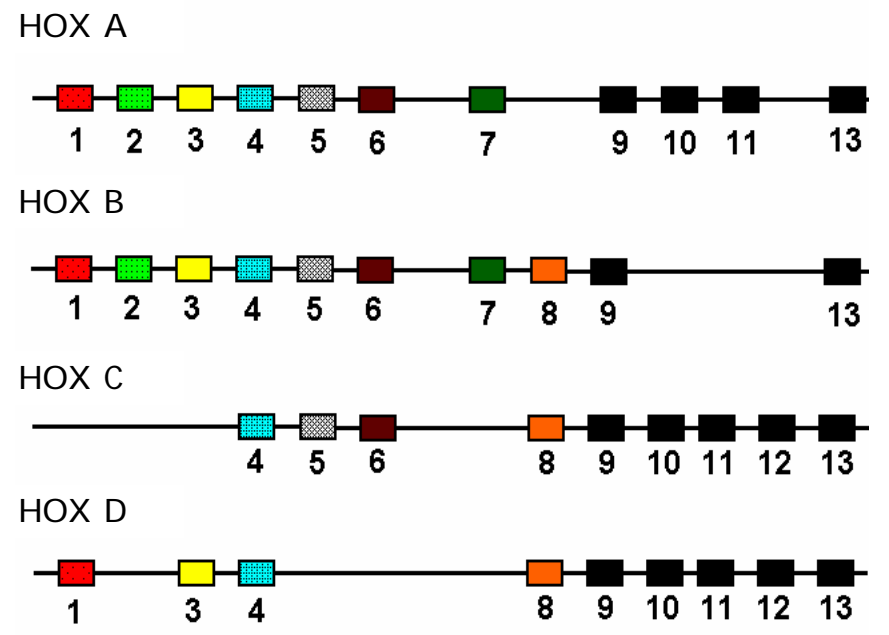

Figura 2.1 - Distribuição dos genes HOX no genoma humano. Os "clusters" A, B, C e D estão localizados respectivamente nos cromossomos 7, 17, 12 e 2

Os produtos dos genes Homeobox são considerados fatores de transcrição, os quais contém uma região de 60 aminoácidos (homeodomí nio) altamente conservada, com capacidade de se "ligar" a sí tios promotores de outros genes e, desta maneira, regular a ativação ou inibição destes genes, principalmente na fase de diferenciação e morfogênese durante o desenvolvimento animal (GEHRING, 1987). O homeodomí nio possui um motivo hélice-alfa-hélice localizado no terminal carboxila da proteí na, o qual forma uma estrutura de ligação nos genes com sí tios alvos (BEDFORD et al., 1993).

O papel dos Homeobox na carcinogênese ainda é discutido (NUNES et al., 2003), mas já foi relacionado com linfomas (BIJL et al., 1997), e detectados em tumores sólidos em fí gado, pulmão e cólon (CILLO, 1995). 
Devido à escassa literatura sobre a participação dos Homeobox em carcinomas epidermóides de cabeça e pescoço, pouco se sabe sobre seu papel no processo da carcinogênese bucal, e diferentes técnicas da Biologia Molecular vêm sendo otimizadas e têm tornando possí vel o entendimento do funcionamento destes genes.

Em 1992, um encontro realizado na Suécia determinou a adoção de uma nomenclatura para os Homeobox em humanos e camundongos (SCOTT, 1992). Em humanos, os Homeobox são citados em maiúsculas (ex.: HOXA4), para camundogos e outras espécies animais em minúsculas e itálicas (ex.: Hoxa4), e quando se faz referência à protế na, a citação é em minúsculo sem itálico (ex.: Hoxa4).

Com finalidade didática de melhor compreensão da literatura selecionada para esta revisão, os genes objetos deste estudo serão abordados, sempre que possí vel, de forma separada dos outros genes Homeobox já publicados na literatura.

\subsection{0 gene HOXB13}

O HOXB13 é um Homeobox agrupado localizado mais próximo do terminal 5 no "cluster" B do cromossomo 17 (Figura 2.2). Devido à capacidade ainda não explicada de colinearidade têmporo-espacial de expressão dos genes Homeobox é esperado estar expresso na extremidade terminal de embriões (Figura 2.3).

Devido à similaridade genética dos HOX contidos num mesmo grupo, a maior parte dos estudos publicados envolve mais de um HOX B em suas análises. 


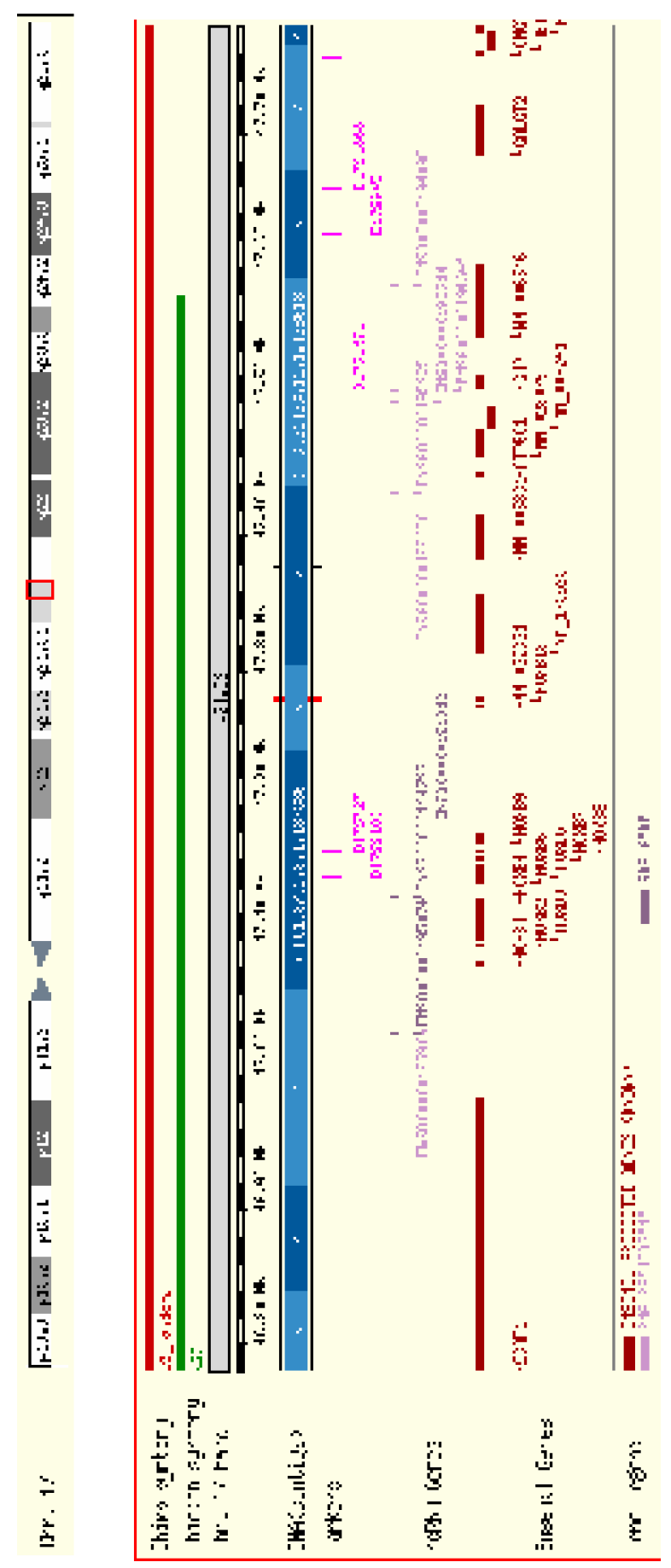

Figura 2.2 - Localização do gene HOXB13 no cromossomo 17 humano 


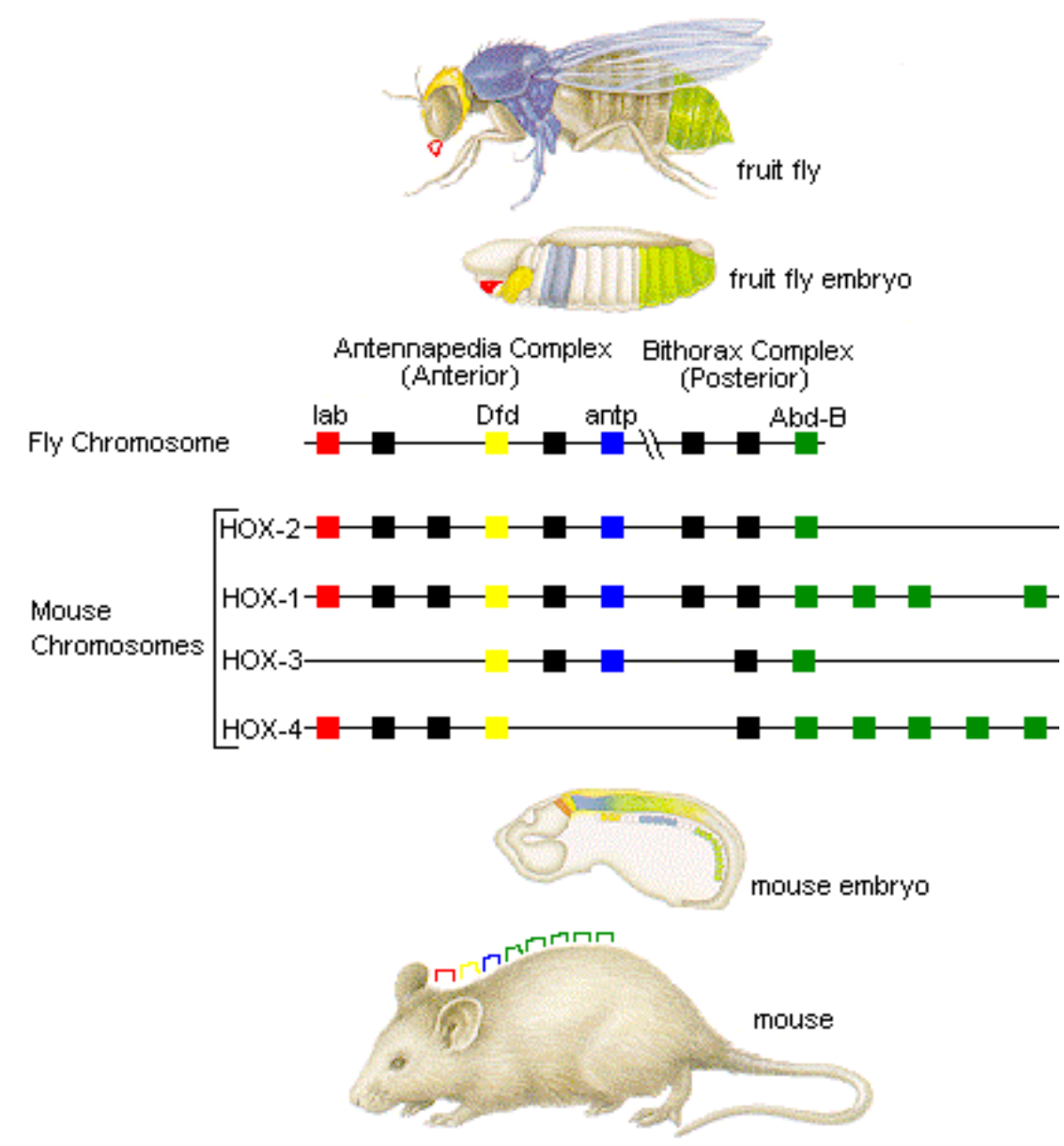

Figura 2.3 - Express ão de genes Homeobox de maneira colinear em Drosophila melanogaster e embri ão de camundongo

Segundo Fisher e Méchali (2003), em um trabalho realizado com cultura de célula p19.6 (Strasbourg, França), foi verificado que a indução da transcrição dos HOX do "cluster" B é dependente da replicação do DNA, ocorrendo mais especificamente na fase $\mathrm{S}$ do ciclo celular.

Zeltser, Desplan e Heintz (1996) seqüenciaram o gene Hoxb13 parálogo para humanos e camundongos. Uma combinação de mapeamento genético e físico demonstrou que o HOXB13 está aproximadamente a 70Kb acima do HOXB9 na mesma orientação de transcrição que o resto do grupo B. Em embriões de 
camundongos, o Hoxb13 mantém a colinearidade têmporo-espacial de expressão na maior parte do eixo do corpo, sendo expresso nas fases mais tardias do desenvolvimento (expressão temporal) e na região do bulbo caudal (distribuição espacial) e, posteriormente, na corda espinhal, trato digestivo e trato geniturinário. Entretanto não se expressa nos membros e bulbos genitais.

Afirma-se que alterações dos genes Hox localizados nas regiões 9-13, principalmente dos clusters $A$ e $D$, são freqüentemente relacionadas com alterações de extremidades e membros em humanos. Expansões polialaní nicas provocadas por repetição imperfeita de um trinucleot́ dio no exon 1 do gene HOXD13 resulta na inserção inserção de 15 resí duos de alanina na região $\mathrm{N}$-terminal da proteí na provocando perda de função da mesma. Como resultado, o indivíduo afetado apresenta sinpolidactilia (KJAER et al., 2002). Conseqüências patológicas similares foram identificadas para o mesmo tipo de alterações mutacionais no gene HOXA13. Entretanto, alterações fenot́ picas mais graves podem estar presentes como no caso da sí ndrome do pé-mão-genitália (GOODMAN et al., 2000).

A perda de função do Hoxb13 está fortemente associada com o crescimento de caudas de animais com deleção homozigótica (camundongos nocaute) para o gene. Levantando a hipótese de que talvez funcione como um repressor da proliferação de células neurais, podendo ser considerado um ativador da apoptose no Sistema Nervoso Central e, igualmente, um inibidor do crescimento nas vértebras caudais (ECONOMIDES; ZELTSER; CAPECCHI, 2003).

A expressão do Hoxb13 foi analisada em camundongos que sofreram deleção do seguimento cromossômico contendo a região do Hoxb1 ao Hoxb9. Os camundongos heterozigóticos para a delação não demonstraram qualquer anormalidade de desenvolvimento, enquanto que os animais homozigóticos 
demonstraram anomalias na região cervical e torácica. A partir destes resultados, os autores concluí ram que apesar da similaridade e proximidade genética deste grupo, a expressão do Hoxb13 parece ser independente da deleção dos outros Hox, mantendo seu padrão colinear de expressão para o modelo animal estudado. Este comportamento foi atribuí do à sua distância de $70 \mathrm{~Kb}$ do último Hox do grupo $\mathrm{B}$, o Hoxb9 (MEDINA-MARTINEZ; BRADLEY; RAMIREZ-SOLIS, 2000).

Carlson et al. (2001) estudaram a expressão de dois genes na posição mais $5^{\prime}$ dos grupos B (Hoxb13) e C (Hoxc10) em Axolotl (salamandras) durante sua fase de desenvolvimento e na regeneração de membros amputados. Durante o desenvolvimento embrionário o HoxB13 se mantém na região mais caudal e, diferente de vertebrados superiores, também apresenta uma expressão no mesênquima da região posterior de órgão e membros. Ambos transcritos do Hoxc10 estão presentes na ponta da cauda e também na região posterior do mesênquima dos membros. No processo de regeneração do membro amputado estes genes retornam a se expressar, mesmo nas regiões anteriores e, principalmente, nas extremidades dos cotos induzindo uma proliferação celular intensa no local.

Economides e Capecchi (2003) observaram que ratos mutantes para Hoxb13 e Hoxd13 exibem morfogênese imperfeita da parte ventral da próstata. Adicionalmente, os ratos mutantes do Hoxb13 exibiram severa hipoplasia dos ductos prostáticos, e um defeito lóbulo-espeá fico onde foi observada uma substituição do epitélio colunar por epitélio cuboidal simples os quais não eram capazes de produzir as proteí nas especí ficas da próstata.

Jave-Suarez et al. (2002) apresentaram fortes evidências de que os genes relacionados com a formação da queratina capilar humana estão regulados pela expressão do HOXC13. A hibridização in situ (ISH) de cortes de couro cabeludo 
humano revelou a presença do transcrito na papila dérmica, se estendendo para matriz, cutícula e região inferior do córtex do bulbo capilar. Sua expressão vai declinando a partir do "mid-cortex".

A fase imunoistoquí mica do mesmo experimento revelou que o Hoxc13 estava restrito aos núcleos dos tricócitos. Técnicas de mapeamento e seqüenciamento genético sugeriram que homeodomí nio do HOXC13 atua em sí tios de transcrição de genes produtores de queratina preferencialmente ativando motivos TTAT ou TAAT diferente dos seus parálogos B13 e D13 que se ligam mais estavelmente em motivos TTAC (JAVE-SUAREZ et al., 2002).

Com a proposta de estudar o padrão de expressão da proteí na Hoxb13 na pele humana, Kömüves et al. (2003) utilizaram as técnicas de ISH, reação de polimerase em cadeia (PCR) e imunoistoquímica durante as fases de desenvolvimento da pele, no processo de regeneração de feridas em fetos e em condições proliferativas, incluindo algumas neoplasias. O transcrito do gene HOXB13 não foi detectado na pele dos fetos humanos, através da técnica de ISH, sugerindo uma baixa expressão deste gene. Entretanto, coma técnica de RT-PCR de cultura de queratinócitos fetais esta expressão estava diminuí a nas células mais diferenciadas, e principalmente na fase de diferenciação celular onde as células entravam em queratinização final. Em pele de fetos de camundongos a expressão da proteí na do Hoxb13 é epidermal e homogeneamente distribuí da não obedecendo ao padrão de colinearidade espacial em nenhum corte transversal de nenhuma das fases gestacionais observadas.

$\mathrm{Na}$ pele de fetos humanos, há uma heterogeneidade parcial de expressão onde a marcação imunoistoquí mica aparece nas camadas média e superior da epiderme, com sinais mais fracos na derme. Com respeito à localização intracelular 
da proteí na na pele de adultos, esta foi detectada no núcleo, enquanto que nas condições proliferativas, incluindo o carcinoma epidermóide, este padrão de expressão era citoplasmático. Apenas o sarcoma de Kaposi exibiu marcação parcialmente nuclear (KÖMÜVES et al., 2003).

Ainda, Mack et al. (2003) analizaram a expressão do Hoxb13 em pele de camundongos. Os autores verificaram que o transcrito está presente nas camadas epidérmica e dérmica da pele, assim como em cultura primária de queratinócitos e de fibroblastos. A análise imunoistoquí mica exibe a proteí na do gene Hoxb13 presente no citoplasma e núcleo da epiderme, nas células do folículo piloso e fibroblastos. Além disso, está superexpressa em áreas de regeneração depois de ferimento provocado.

Os autores então estudaram camundongos mutantes homozigóticos (nocaute Hoxb13 $3^{-/-}$) para o Hoxb13. Foi observado que a pele do camundongo adulto, apesar de parecer fenotipicamente normal, exibe uma maior espessura devido ao aumento de depósito de hialuronan na matriz extracelular. Além disso, nestes camundongos, as feridas provocadas por incisão na pele cicatrizam mais rápido do que nos camundongos normais e o colágeno se reconstitui de maneira mais organizada (MACK et al., 2003).

Até o momento, o último trabalho publicado relacionando a expressão do HOXB13 em cânceres humanos foi o de Ma et al. em 2004. Os autores observaram que a superexpressão dos genes HOXB13 e IL17BR prediz a recorrência e progressão da doença em pacientes com câncer de mama sob tratamento coadjuvante com tamoxifeno, droga utilizada para adenocarcinomas ricos em receptores de estrógenos. Além disso, as células epiteliais de mama submetidas à superexpressão destes genes apresentam alterações morfológicas caracterizadas 
pela redução do número de junções intercelulares, aumentando a possibilidade de mobilidade e migração celular.

\subsection{O gene HHEX}

O gene HHEX é um Homeobox não agrupado altamente conservado entre os vertebrados. Em humanos, está localizado no cromossomo 10 (Figura 2.4) e codifica uma proteí na homônima de 271 aminoácidos a qual contém um domí nio rico em prolina no seu terminal-N (aminoácidos 1-136), além do homeodomí nio (aminoácidos137-196) localizado na sua porção central (TANAKA et al., 1999).

Além de ser conhecido como Homeobox rico em prolina (Prh - Proline-rich homeobox) o gene HHEX já foi anteriormente denominado hex. Por último, teve sua nomenclatura modificada pelo "Comitê de Nomenclatura do Peixe Zebra" para evitar confusão com o nome do gene hexosaminidase (hex) e tem hoje esta nomenclatura utilizada tanto para humanos (HHEX) quanto para camundongos (hhex). Seu nome foi sugerido devido ao fato de ter sido primeiro identificado como um Homeobox expresso em células hematopoiéticas (hematopoietically expressed homeobox (CROMPTON et al., 1992; LIAO et al., 2000).

Assim como muitos outros Homeobox, a literatura referente ao hhex é mais abundante no que diz respeito às fases de desenvolvimento e organogênese em diversos modelos animais. 


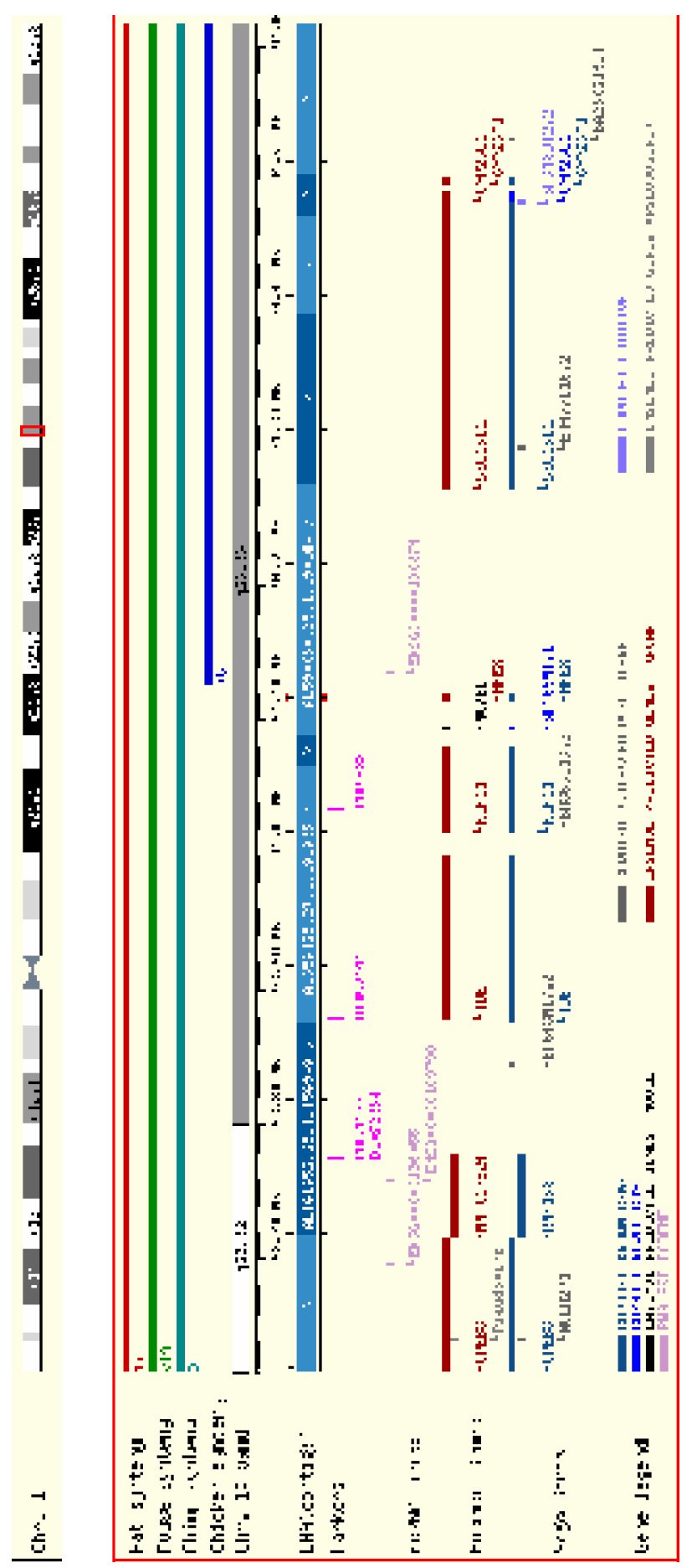

Figura 2.4 - Localização do gene HHEX no cromossomo 10 humano 
O hhex, assim como outros genes (Scl, LMO2), são fatores de transcrição implicados na hematopoiese em mamíferos (CROWHURST; LAYTON; LIESCHKE, 2002) e que funcionam como um repressor aparentemente envolvido no padrão de desenvolvimento do seguimento anterior e do eixo dorso-ventral de embriões de Xenopus e peixe zebra (BRICKMAN et al., 2000), seus principais modelos animais de estudo.

Ademais, em embriões de camundongos, o hhex aparece expresso na porção anterior visceral e rostral do endoderma estando supostamente relacionado com o desenvolvimento de parte do Sistema Nervoso Central (SNC), sendo essencial para o desenvolvimento normal do rombencéfalo, fí gado e glândula tireóide (MARTINEZ BARBERA et al., 2000).

Para Bedford et al. (1993), a expressão do HHEX em células hematopoiéticas, tanto em humanos quanto em camundongos, não é onipresente, mas restrita a algumas linhagens como: progenitores mielóides, de células da medula óssea e células linfóides. Entretanto tem fraca expressão em monócitos e está ausente em timócitos, fígado fetal, em linhagens de fibroblastos, em células eritróides e em linfócitos T. Então, ao estudar cultura de células de leucemias e linfomas, os autores verificaram que em leucemia pró-linfoć tica T o gene HHEX não está expresso, contudo, células B derivadas tanto de leucemia quanto de linfomas (com exceção do linfoma não-Hodgkin) mostraram expressão do gene.

O hemangioblasto é considerado um progenitor comum para as células endoteliais e as células sangüí neas (RISAU; FLAMER, 1995). É possí vel que, nos estágio de desenvolvimento do peixe zebra, o hhex esteja expresso nesta célula de forma a gerar células endoteliais e células da linhagem sanguínea. Pois, sua superexpressão acarreta em formação precoce e ectópica de células endoteliais, 
enquanto que sua ausência parece ser compensada pela expressão do gene scl sugerindo uma regulação cruzada entre estes dois genes. A expressão do hhex está significantemente reduzida em embriões com mutação do gene cloche indicando uma possí vel posição abaixo da cascata de regulação ("downstream") do Homeobox hhex na diferenciação destas células (LIAO et al., 2000).

Ainda não está claro como os angioblastos (ou hemangioblastos) são selecionados de dentro do mesênquima na fase embrionária. Há evidências de que o hhex se expressa nos primeiros estágios de desenvolvimento do embrião, ativando o gene flk-1 responsável pela diferenciação endotelial (angiogênese e vasculogênese), e diminuindo sua expressão à medida que a diferenciação endotelial começa. A expressão tardia do hhex em embriões de camundongo aparece nas regiões onde vasos definitivos serão formados (ex.: aorta), na região onde presumivelmente surgirá o endocárdio, fígado e tiróide (RODRIGUES et al., 2001; THOMAS; BROWN; BEDDINGTON, 1998).

Sekiguchi et al. (2001), através da técnica de RT-PCR, mostraram baixí ssimas expressões do hhex em aorta normal de camundongos adultos. Entretanto em cultivo primário de células vasculares de musculatura lisa derivadas da aorta de ratos e coelhos foi encontrado uma expressão elevada do mRNA do mesmo gene. Os autores sugerem que a expressão deste gene depende do estágio de diferenciação celular do músculo liso. Também verificaram que após injúria do vaso com musculatura lisa a expressão o hhex aumenta indicando sua participação na indução da neoformação de músculo liso de vasos.

Um alvo importante do BMP é o Homeobox Hhex o qual está expresso em vários tipos celulares durante a embriogênese na formação do eixo antero-posterior, na vasculogênese, no desenvolvimento de vários órgãos de origem endodérmica 
incluindo o fí gado e a tireóide. Segundo Zhang et al. (2002), em embriões de aves, o BMP2 está expresso na região anterior e lateral do endoderma na fase de tardia da gástrula sendo requerido para regulação de vários genes envolvidos no mesoderma cardiogênico, desenvolvimento cardiológico e do fígado em uma relação recí proca com outros fatores de crescimento. Os autores verificaram que o hhex requer sinalização autócrina do BMP2 em embriões de aves; também identificaram sítios receptores do BMP na região promotora do gene hhex em camundongos.

O que confere a responsividade da região promotora do hhex a sinalização do BMP são duas caixas (Box) CAGAG na sua composição, pois deleção destas áreas impede a expressão do gene. Os resultados mostraram que a expressão do hhex no endoderma requer sinalização autócrina do BMP revelando um crucial papel da famí lia BMP no topo da hierarquia da expressão de genes que levam a diferenciação de hepatócitos. Assim a expressão do BMP é requerida para ativação de genes reguladores que governam os estágios primários de desenvolvimento do coração e do fí gado. Para aves, a sinalização parácrina do BMP ativa genes cardiogênicos no mesoderma, enquanto que a sinalização autócrina ativa o hhex no mesoderma (ZHANG et al., 2002).

Para Guo e al. (2003), o hhex não é necessário para formação inicial dos hemangioblastos, mas sim para a diferenciação apropriada destes, uma vez que estes já estão formados. Em ratos mutantes homozigóticos (nocaute $h \ln ^{-1-}$ ) não há formação dos tecidos linfóides e mielóides, afirmando o papel do hhex na geração de células tronco hematopoiéticas. Além disso, o BMP-4, Fkl-1, Runx-1 e Scl estão trabalhando acima ou de igual forma na cascata do hhex. O IGF-1, Gata 1, EKLF, NF-AT e PPARgamma requerem a expressão do hhex estando presumivelmente regulados abaixo dele. 
Crowhurst, Layton e Lieschke (2002) descreveram a mielopoiese e mielócitos de peixes zebra numa "procura" de mutantes a fim de entender o desenvolvimento dos mielócitos durante a morfogênese, funcionalmente e no nível molecular. Focaram-se principalmente em mielócitos fagocitários. Tanto a superexpressão do hhex quanto do $S c /$ aumentou a expressão dos marcadores vasculares flk1 e tie1 e dos marcadores de eritrócitos (o-dianisidine, gata1), concluindo que ambos os fatores de transcrição estão envolvidos no destino dos hemangioblastos. Em 1998 Liao et al. (1998) já haviam chegado a resultados semelhantes, e, dois anos depois relataram uma possível regulação destes genes ao comando de um gene desconhecido quando mutado no cloche (LIAO et al., 2000); posteriormente denominado cloche pelos autores.

Estudando o desenvolvimento de células B em camundongos, Bogue et al. (2003) verificaram que o hhex é requerido no desenvolvimento de todos os estágios destas células exceto para os plasmócitos. Pois, ao provocarem uma deficiência homozigótica do gene verificaram que o resultado era letal para o embrião, e desenvolvendo ratos quiméricos $h$ hex $x^{-/-} \operatorname{Rag} 1^{-1-}$, os embriões sobreviviam, mas desenvolviam uma série de anomalias das células linfopoiéticas incluindo a redução do número de células-B maduras, pré-células $B$ e células-B CD5+ (peritoneal). Ainda, sua ausência resulta na falha em gerar anticorpos lgG para antígenos dependentes de células T e finalmente um acúmulo de células CD19+.

Em células eucarióticas o 'Fator 4E de Iniciação de Tradução' (elF4E) está envolvido na modulação do crescimento celular e é essencial para sua sobrevivência. O bloqueio de sua função em vários organismos resulta em letalidade embrionária. Segundo Topisirovic et al. (2003), o HHEX é um regulador negativo do elF4E em cultura de células mielóides. Os autores encontraram que o mRNA do 
elF4E está presente em todas as células, enquanto que o HHEX está restrito a alguns tipos celulares. Desta forma, o elF4E está modulado em situação tecido especí fica pelo HHEX, já que em uma variedade de linfomas de células-B, o elF4E está superexpresso e o HHEX tem sua expressão diminuí da de acordo com o grau de diferenciação celular (MANFIOLETTI et al., 1995; WANG et al., 1999)

Os hemangioblastos dão origem a dois tipos de hematopoiese embrionária: a primitiva e a definitiva (CHOl et al., 1998). Guo et al. (2003) demonstraram que os hemangioblastos primitivos não são capazes de reativar completamente a hematopoiese em indiú duos transplantados por serem capazes de produzir eritrócitos nucleados, com globinas embrionárias e monócitos, enquanto que os hemangioblastos definitivos dão origem a eritrócitos nucleados e a linhagem hematopoiética e podem restaurar toda hematopoiese em adultos transplantados. Além disso, verificaram que a deleção homozigótica do hhex em embriões murinos é letal nos 11 a 13 dpc (dias pós coito) por promover o desenvolvimento truncado do rombencéfalo, tiróide e fígado. Sugerindo a regulação destas estruturas endodérmicas anteriores.

A literatura sobre o Hhex também se refere ao seu papel no desenvolvimento embrionário de alguns órgãos derivados do endoderma. Tanaka et al. (1999) investigaram a expressão do hhex em fígado de ratos e em várias linhagens celulares através de Northen-blot. Altos ní veis de mRNA do hhex foram isolados de hepatócitos frescos. Também estavam presentes em células de hepatoma bem diferenciado e ausente em linhagens de células de hepatomas pobremente diferenciados. O nível de hhex em fígado de embriões é alto até o 20 dia de gestação, caindo bruscamente no rato adulto. Quando feito uma hepatectomia, as células remanescentes retornam a expressar o gene. Os resultados sugerem que o 
mRNA do hhex pode estar relacionado com a diferenciação e/ou manutenção do estado de diferenciação dos hepatócitos.

Ghosh et al. (2000) demonstraram que a proteí na hhex esta presente tanto no núcleo quanto no citoplasma de células cultivadas de embriões de ratos. $\mathrm{O}$ exame imunoistoquí mico em embriões exibe marcação nas áreas de desenvolvimento de ilhas sangüí neas ("blood island") e diverí culo hepático. Em particular, a expressão do hhex é nuclear nas células endodermais do divertículo hepático enquanto é citoplasmática nas células laterais da região formadora do fígado. Os autores sugerem que o hhex esteja envolvido na diferenciação precoce dos hepatócitos e que o padrão de expressão compartimentalizada de sua proteí na desempenha um importante papel no desenvolvimento embrionário dos animais estudados.

Denson et al. (2000) encontraram o gene HHEX expresso tanto no fí gado adulto quanto no fí gado em desenvolvimento (cultura de células hepáticas humanas do "American Type Culture Collection" - ATCC). Identificando um suposto sí tio de ligação para o HHEX na região promotora do gene co-transportador fígado específico de ácido biliático $\mathrm{Na}+$ (nTCP) e assim, um possí vel papel do gene na função hepática.

Keng et al. (2000) concorda que o Hhex é essencial para o desenvolvimento do fí gado, mas embriões com deleções $h$ hex $x^{-/}$ou $h h x^{+/-}$não exibiram anormalidades histopatologicamente detectável em pulmão, tireóide ou em outros órgãos derivados do endoderma. Apenas a linhagem de monócitos foi afetada na hematopoiese primitiva nos embriões $h h e x^{-1}$. 


\section{PROPOSIÇÃO}

A proposição do presente trabalho foi estudar o padrão de expressão dos transcritos dos genes Homeobox HOXB13 e HHEX em carcinoma epidermóide de boca através das técnicas de RT-PCR e hibridização in situ, e sua eventual relação com fatores prognósticos. 


\section{MATERIAL E MÉ TODOS}

Esta pesquisa corresponde à parte do projeto mais amplo que corre com o tí tulo "Estudo da expressão de genes Homeobox em carcinoma epidermóide de boca" sob a responsabilidade do Prof. Dr. Fábio Daumas Nunes e financiado pela agência de fomento FAPESP (projeto $n^{\circ}$ 01/13644-6). O projeto supracitado teve sua formulação baseada nos resultados obtidos da pesquisa denominada "Genoma do câncer da cabeça e pescoço" conduzida pelo Instituto Ludwig de Pesquisa do Câncer de São Paulo, o qual identificou a presença dos genes Homeobox em carcinomas epidermóides (dados não publicados).

O "Estudo da expressão de genes Homeobox em carcinoma epidermóide de boca" foi aprovado pela Comissão de Ética para Análise de Projetos de Pesquisa (CAPPesq) da diretoria Clí nica do Hospital das Clí nicas e da Faculdade de Medicina da Universidade de São Paulo sob o número de Protocolo 566/01 (Anexo A), estando a Comissão de Ética e Pesquisa da Faculdade de Odontologia da USP ciente e de acordo (CEP/FO - 163/02). Os pacientes incluí dos na amostra desta pesquisa foram devidamente comunicados e tiveram assinados seus termos de consentimento livre e esclarecido (Anexo B). 


\subsection{Obtenção dos espécimes}

Trinta pacientes consecutivos portadores de carcinoma epidermóide de boca (CEB) oriundos do Serviço de Cirurgia de Cabeça e Pescoço do Hospital das Clí nicas da Faculdade de Medicina da Universidade de São Paulo (HC-FMUSP) foram incluí dos no presente estudo. O diagnóstico histopatológico foi firmado através de biópsia incisional prévia e, durante o ato cirúrgico, foram removidos fragmentos de tecido tumoral (TT) e do tecido não tumoral adjacente à lesão (NT).

$\mathrm{Na}$ análise histopatológica das lesões foram avaliados os seguintes critérios: margens cirúrgicas comprometidas, invasão perineural e vascular, espessura tumoral e estádio pTNM. A forma de remoção dos fragmentos fornecidos para este estudo foi realizada de maneira que não implicasse em prejú zo do estudo da peça e das margens.

\subsection{Processamento dos espécimes}

Os tecidos removidos foram organizados em pares de TT e NT do mesmo paciente, numerados e imediatamente fixados em paraformaldeí do 4\%. Em seguida foram fragmentados e tiveram parte dos fragmentos submetidos à extração do RNA total, e parte submetidos à realização da técnica de hibridização in situ (ISH). 


\subsection{Caracteń sticas clí nicas, histopatológicas e classificação da amostra}

Os dados presentes no Quadro 4.1 exibem as caracteń sticas clínicas dos pacientes e os parâmetros indicativos de fatores prognósticos utilizados na análise estat́ stica. Os fatores prognósticos analisados foram selecionados de acordo com o estabelecido pela literatura (ver item 2.2 do capí tulo de revisão).

Cortes corados em Hematoxilina e Eosina (HE) dos fragmentos de tecidos tumorais obtidos foram graduados em bem, moderadamente e pouco diferenciados. Esta avaliação histopatológica e gradação dos tumores são rotineiramente utilizadas pelo Serviço de Anatomia Patológica do Hospital das Clínicas (HC-FMUSP). As lesões são graduadas numa escala de três (bem, moderadamente ou pouco diferenciado) de acordo com o ní vel de semelhança com o tecido normal e produção de queratina.

Quanto à Classificação UICC ("Union Internationale Contre le Câncer") os pacientes foram divididos em precoces (Estadios I e II) e avançados (III, IV) (UICC, 1992). Os dados pTNM também foram avaliados separadamente ( $\mathrm{pT}$ e pN) para facilitar a análise estat́í stica e interpretação dos resultados. O dado metástase (M) foi excluí do da análise estat́ stica já que todos os pacientes eram negativos.

É importante salientar que nem toda amostra foi utilizada para todas as fases do trabalho devido a limitações dos dados clínicos e dificuldades na manipulação das amostras durante a fase de otimização de cada uma das etapas laboratoriais. 


\begin{tabular}{|c|c|c|c|c|c|c|c|c|c|c|c|c|}
\hline No. & Idade & Sexo & Cor & Local & Difer & UICC & TNM & $\begin{array}{l}\text { Espessura } \\
\text { (cm) }\end{array}$ & $\begin{array}{l}\text { Invasão } \\
\text { vascular }\end{array}$ & $\begin{array}{c}\text { Invasão } \\
\text { perineural }\end{array}$ & $\begin{array}{c}\text { Invasão } \\
\text { adjacente }\end{array}$ & Margem \\
\hline 1 & 55 & $\mathrm{~F}$ & $B$ & $\begin{array}{l}\text { bord. } \\
\text { ling }\end{array}$ & BD & III & T2N1M0 & 0,7 & - & + & - & - \\
\hline 2 & 55 & $F$ & $B$ & $\begin{array}{l}\text { base. } \\
\text { ling }\end{array}$ & MD & IV & PT2PN2M0 & 1 & - & + & - & + \\
\hline 3 & 50 & $M$ & B & $\begin{array}{l}\text { bord. } \\
\text { ling }\end{array}$ & MD & III & PT2N1MO & 1,2 & - & + & - & * \\
\hline 4 & 70 & $\mathrm{~F}$ & $B$ & $\begin{array}{l}\text { bord. } \\
\text { ling }\end{array}$ & MD & IV & PT1N2AMO & 0,3 & - & - & - & * \\
\hline 5 & 87 & $M$ & $P$ & maxila & MD & IV & T4NOMO & 2 & - & - & + & + \\
\hline 6 & 77 & $M$ & $B$ & labio inf & MD & IV & T4N0M0 & 1,2 & - & - & - & - \\
\hline 7 & 60 & $\mathrm{M}$ & $B$ & soalho & MD & IV & T4N3M0 & 4 & + & + & + & - \\
\hline 8 & 68 & $\mathrm{M}$ & B & labio inf & $\mathrm{BD}$ & II & PT2N0M0 & 1,3 & - & - & - & * \\
\hline 9 & 69 & $\mathrm{~F}$ & $B$ & $\begin{array}{l}\text { bord. } \\
\text { ling }\end{array}$ & BD & II & T2NOMO & 0,2 & $\mathrm{NC}$ & $\mathrm{NC}$ & $\mathrm{NC}$ & - \\
\hline 10 & 78 & $\mathrm{~F}$ & $B$ & $\begin{array}{l}\text { bord. } \\
\text { ling }\end{array}$ & $\mathrm{BD}$ & I & T1N0M0 & 0,2 & - & - & - & * \\
\hline 11 & 50 & $\mathrm{M}$ & $B$ & mento & $\mathrm{BD}$ & IV & T4NOMO & 0,9 & - & + & - & - \\
\hline 12 & 50 & $\mathrm{M}$ & B & I ngua & $\mathrm{BD}$ & I & T1N0M0 & 0,6 & - & - & - & * \\
\hline 13 & 25 & $\mathrm{~F}$ & B & lingua & MD & IV & T4NECMO & 2 & - & + & + & - \\
\hline 14 & 56 & $\mathrm{~F}$ & $B$ & $\begin{array}{c}\text { base. } \\
\text { ling }\end{array}$ & MD & IV & T4NOM0 & 1,1 & - & + & + & * \\
\hline 15 & 50 & $\mathrm{M}$ & $B$ & soalho & $\mathrm{NC}$ & I & T1N1M0 & $\mathrm{NC}$ & - & - & & * \\
\hline 16 & 58 & $M$ & $\mathrm{NC}$ & $\begin{array}{c}\begin{array}{c}\text { soalho/ } \\
\text { lin }\end{array} \\
\end{array}$ & MD & IV & T4N2BMO & 3,5 & - & + & + & * \\
\hline 17 & 67 & $\mathrm{M}$ & $\mathrm{NC}$ & Ingua & MD & II & PT2NOMO & 2,2 & - & + & - & - \\
\hline 18 & 80 & M & $\mathrm{NC}$ & I ngua & MD & IV & T4NOMO & 1,2 & - & - & + & - \\
\hline 19 & 58 & $\mathrm{M}$ & $B$ & reb. inf. & $\mathrm{NC}$ & II & T2NOM0 & 0,7 & + & + & + & - \\
\hline 20 & 49 & $\mathrm{~F}$ & $B$ & $\begin{array}{c}\text { ling } \\
\text { base }\end{array}$ & PD & IV & T4N3M0 & 1,8 & $\mathrm{NC}$ & $\mathrm{NC}$ & + & $\mathrm{NC}$ \\
\hline 21 & 19 & $\mathrm{M}$ & B & lingua & $\mathrm{MD}$ & IV & T4N2M0 & $\mathrm{NC}$ & $\mathrm{NC}$ & $\mathrm{NC}$ & $\mathrm{NC}$ & $\mathrm{NC}$ \\
\hline 22 & 70 & $M$ & $\mathrm{NC}$ & lab inf & $\mathrm{NC}$ & $\mathrm{NC}$ & $\mathrm{NC}$ & $\mathrm{NC}$ & $\mathrm{NC}$ & $\mathrm{NC}$ & $\mathrm{NC}$ & $\mathrm{NC}$ \\
\hline 23 & 60 & $\mathrm{M}$ & $B$ & oro far & $\mathrm{NC}$ & $\mathrm{NC}$ & NC & $\mathrm{NC}$ & $\mathrm{NC}$ & $\mathrm{NC}$ & $\mathrm{NC}$ & $\mathrm{NC}$ \\
\hline 24 & 38 & $\mathrm{~F}$ & $A$ & lingua & $\mathrm{BD}$ & II & T2NOMO & 0,6 & - & - & - & * \\
\hline 25 & 62 & $\mathrm{M}$ & $B$ & lin.bord & MD & IV & T4NXMO & 1,2 & - & + & + & $\mathrm{NC}$ \\
\hline 26 & 40 & $\mathrm{~F}$ & $B$ & lingua & $\mathrm{NC}$ & $\mathrm{NC}$ & $\mathrm{NC}$ & 0,2 & $\mathrm{NC}$ & $\mathrm{NC}$ & $\mathrm{NC}$ & $\mathrm{NC}$ \\
\hline 27 & 17 & $\mathrm{~F}$ & B & trig & $\mathrm{NC}$ & IV & T4N0M0 & $\mathrm{NC}$ & $\mathrm{NC}$ & $\mathrm{NC}$ & $\mathrm{NC}$ & $\mathrm{NC}$ \\
\hline 28 & 70 & $\mathrm{M}$ & $B$ & lingua & BD & II & PT2N0M0 & 0,4 & - & - & + & * \\
\hline 29 & 50 & $M$ & $B$ & Ingua & PD & IV & PT4N1M0 & 1,5 & $\mathrm{NC}$ & $\mathrm{NC}$ & $\mathrm{NC}$ & + \\
\hline 30 & 47 & $M$ & B & ling bor & $\mathrm{NC}$ & IV & T3N2M0 & $\mathrm{NC}$ & - & + & $\mathrm{NC}$ & $\mathrm{NC}$ \\
\hline
\end{tabular}

$\mathrm{M}=$ masculino, $\mathrm{F}=$ feminino, $\mathrm{NC}=\mathrm{n} \tilde{\mathrm{a}}$ consta,+ presente, - ausente, ${ }^{*}$ livre ap ós ampliação das margens, $\mathrm{B}=$ branco, $\mathrm{A}=$ amarelo, $\mathrm{P}=$ pardo, $\mathrm{BD}=$ Bem Diferenciado, $\mathrm{MD}=$ Moderadamente Diferenciado, $\mathrm{PD}=$ Pouco diferenciado, margem $=$ margem comprometida, Difer $=$ grau de diferenciação histológico, TNM = par âmetro de classifica ção tumotal onde T étamanho, $N$ presença e tamanho de nódulos metastáticos e M presença de Metástase, UICC = Classificação tumoral da Uni ão Internacional Contra o C âncer.

Quadro 4.1 -Características clínicas e histopatol ógicas dos pacientes, classifica ção UICC e pTNM 


\subsection{Fase experimental}

\subsubsection{Obtenção do RNA}

O RNA total dos fragmentos de TT e NT foi extraí do, separadamente, segundo a técnica do TRIzol® seguindo as recomendações do fabricante (Invitrogen, Gaithesburg, MD, USA) e livres de RNase. O material foi pesado em balança de precisão e posteriormente triturado até consistência de pó com auxí lio de grau e pistilo contendo nitrogênio líquido. Para cada 100mg de tecido foram adicionados $1 \mathrm{ml}$ de $\mathrm{TR} / z o \mathrm{I}$, e, após homogeneização, o material foi transferido para tubo Eppendorf e armazenado em gelo triturado durante 5 minutos.

Em seguida, o conteúdo foi colocado a temperatura ambiente durante 3 minutos e o lí quido adquirido, após adição de $200 \mu \mathrm{l}$ de clorof órmio, foi submetido a centrifugação a $15.000 \mathrm{rpm}$ a $4^{\circ} \mathrm{C}$ por 15 minutos. Assim, três fases diferentes foram formadas: uma fase aquosa que corresponde ao RNA total do tecido triturado; uma fase branca intermediária que corresponde à proteí na total; e uma fase cor-de-rosa que corresponde ao DNA total da amostra. A fase aquosa foi transferida para outro tubo Eppendorf e o restante armazenado em freezer a $-80^{\circ} \mathrm{C}$ ou mesmo desprezado.

Ao RNA total obtido foram acrescentados $500 \mu l$ de isopropanol e nova centrifugação foi realizada. Desta vez, o sobrenadante foi desprezado, o precipitado lavado com etanol a $70 \%$ e o corpo de fundo ("pellef") secado a vácuo a $25^{\circ} \mathrm{C}$ sem sofrer desidratação. O precipitado foi dissolvido em água destilada deionizada estéril 
tratada com DEPC (dietil-pirocarbonato) num volume de 25 a $50 \mu \mathrm{l}$, dependendo do tamanho do corpo de fundo ("pellef"). A quantificação do RNA obtido de cada amostra foi aferida por leitura da absorbância através de espectrofotômetro (Beckmann DU-640) e calculado pela fórmula: OD x diluição x 40 / 1000. Todas as amostras de RNAs apresentaram pureza entre 1,8 e 2,0. A integridade do RNA foi verificada em gel de agarose com formaldeí do (Figura 4.1).

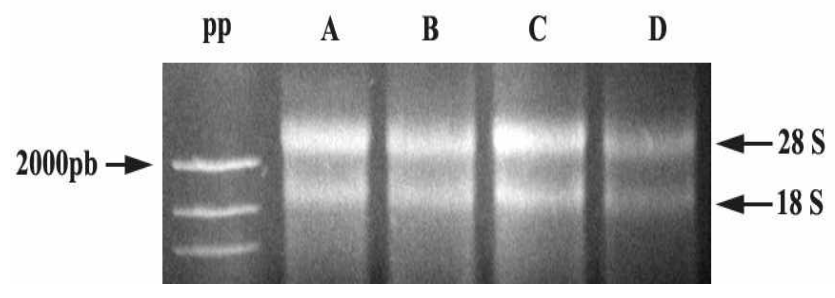

Figura 4.1 - Exemplo de resultado obtido com gel de integridade de RNA mostrando duas bandas $28 \mathrm{~S}$ e 18S. PP - marcador de pares de base. Em A, B, C e D os RNAs dos genes HOXB13, HHEX, $\beta$ actina e novamente $\beta$ actina, respectivamente

4.4.2 Transcrição Reversa seguida de Reação de Polimerase em Cadeia ("Reverse Transcriptase Polimerase Chain Reaction" - RT-PCR)

O RNA obtido foi submetido a tratamento com DNase I antes da sua transcrição reversa segundo instruções do fabricante (RT-PCR - "Reverse transcriptase polymerase chain reaction", Invitrogen, Gaithesburg, MD, USA). Cada $4 \mu \mathrm{g}$ de RNA foi tratado com $2 \mu$ l de DNase I, para degradação do DNA residual, e 
posteriormente adicionados $2 \mu$ de oligo(dT) (Invitrogen, Gaithesburg, MD, USA) e $13 \mu$ le água miliQ para completar um volume total de $20 \mu l$.

Os tubos foram aquecidos a $70^{\circ} \mathrm{C}$ por $10 \mathrm{~min}$, resfriados rapidamente, e tratados com solução tampão apropriada, DTT ("Dithiothreitol”) e dNTPs ("deoxynucleoside triphosphate"). Os tubos permaneceram à temperatura de $25^{\circ} \mathrm{C}$ durante 10 minutos, sendo então aquecidos por 2 minutos a $42^{\circ} \mathrm{C}$. Aos tubos foi adicionado $1 \mu \mathrm{l}$ da enzima superscript II (Invitrogen, Gaithesburg, MD, USA), e então mantidos a $42^{\circ} \mathrm{C}$ por 50 minutos. Para inativar a enzima, a reação foi finalizada mantendo os tubos a $70^{\circ} \mathrm{C}$ durante 15 minutos. Os cDNAs obtidos foram armazenados em freezer a $-20^{\circ} \mathrm{C}$ até o uso.

\subsubsection{Reação de Polimerase em Cadeia ("Polimerase Chain Reaction" - PCR)}

Os cDNAs foram amplificados pela técnica de PCR utilizando-se iniciadores espeć́ ficos para seqüência dos genes HHEX, HOXB13 e também o gene constitutivo da $\beta$-actina (Quadro 4.2). Esses iniciadores ("primers") foram desenhados com base em seqüências obtidas no GeneBank, com aux́́ lio do software GeneTool ${ }^{\circledR}$, sendo as seqüências dos "primers forward" (senso) e "reverse" (anti-senso) localizadas em diferentes exons. 


\begin{tabular}{|l|l|l|l|c|c|}
\hline \multicolumn{1}{|c|}{ Gene } & Acesso & Senso 5 $\rightarrow \mathbf{3}$ & Anti-senso 5 $\rightarrow \mathbf{3}$ & Produto (pb) & $\begin{array}{c}\text { Tamanho da } \\
\text { amostra }\end{array}$ \\
\hline HOXB13 & NM_006361 & cgtggtggggagagcgagctg & agggagtcatgtcgcggttc & $561 \mathrm{pb}$ & 22 \\
\hline HHEX & NM_002729 & ccctgggcaaacctctactctg & atggccctcaatgtccacttcct & $434 \mathrm{pb}$ & 21 \\
\hline B-actina & BC_016045 & ccttcctgggcatggagtcctg & ggagcaatgatcttgatcttc & $457 \mathrm{pb}$ & 30 \\
\hline
\end{tabular}

Acesso = número de acesso no GeneBank, pb = pares de bases.

Quadro 4.2 -Seqüência dos iniciadores dos genes HOXB13, HHEX e $\beta$ actina

Para cada reação de amplificação, os seguintes reagentes foram adicionados a um tubo de 0,5ml: 0,5 $\mu \mathrm{l}$ de cDNA, iniciadores senso e anti-senso, dNTPs (Invitrogen), tampão para PCR (Invitrogen), enzima Taq polimerase (Invitrogen) e água miliQ autoclavada. O equipamento utilizado foi o termociclador PTC-100 Peltier-Effect Cycling (MJ Research, Inc). Cada reação de amplificação foi realizada em triplicata, e com o uso de soluções "MIX" (com o intuito de padronizar a pipetagem) contendo todos os reagentes, exceto o cDNA. Os tubos foram submetidos às seguintes condições de ciclagem:

- HOXB13: pré-denaturação a $94^{\circ} \mathrm{C}$ por $3 \mathrm{~min}$, denaturação a $94^{\circ} \mathrm{C}$ por $1 \mathrm{~min}$, $67^{\circ} \mathrm{C}$ por seg (temperatura e pareamento ou "annealing"), $72^{\circ} \mathrm{C}$ por $1 \mathrm{~min}$ em 37 ciclos. Foram adicionados 10 minutos a $72^{\circ} \mathrm{C}$ para extensão final.

- $\quad$ HHEX: Inicialmente o produto foi denaturado por $3 \mathrm{~min}$ a $94^{\circ} \mathrm{C}$. Os ciclos constaram de $94^{\circ} \mathrm{C}$ por $1 \mathrm{~min}, 59^{\circ} \mathrm{C}$ por seg, $72^{\circ} \mathrm{C}$ por $1 \mathrm{~min}$ em 35 ciclos. Foram adicionados 10 minutos a $72^{\circ} \mathrm{C}$ para extensão final.

- $\quad \beta$ - actina: Inicialmente o produto foi denaturado por $3 \min$ a $94^{\circ} \mathrm{C}$. Os ciclos constaram de $94^{\circ} \mathrm{C}$ por $1 \mathrm{~min}, 55^{\circ} \mathrm{C}$ por seg, $72^{\circ} \mathrm{C}$ por $1 \mathrm{~min}$ em 39 ciclos. Foram adicionados 10 minutos a $72^{\circ} \mathrm{C}$ para extensão final.

A amplificação da $\beta$ - actina, por ser um gene constiutivo, foi utilizada para confirmar a reatividade do cDNAs dos tecidos incluí dos na amostra. Todos os tecidos foram testados estando todos positivos para a mesma. Um exemplo da 
amplificação da - ßactina pode ser verificado na Figura 4.2. Entretanto, o tamanho do produto amplificado não era compatí vel com um tamanho de sonda desejável para a fase de hibridização in situ. Assim, apenas para confecção da sonda, novos iniciadores foram confeccionados (Quadro 4.2) e o produto amplificado submetido às etapas subseqüentes.

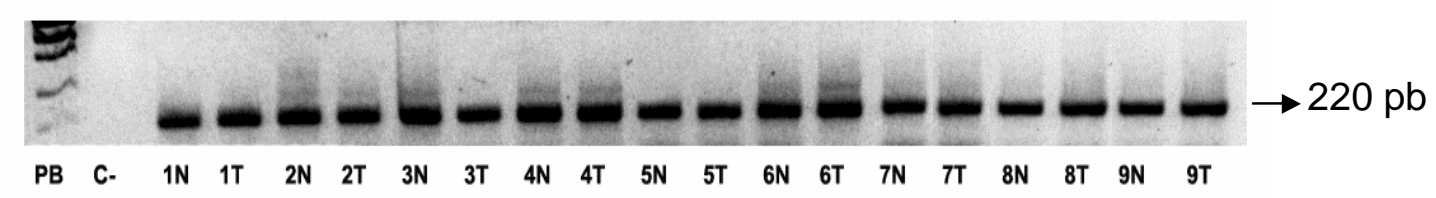

Legenda: $\mathrm{C}-$ = controle negativo, $\mathrm{pb}=$ pares de base, $\mathrm{N}=$ normal, $\mathrm{T}=$ tumor

Figura 4.2 - Exemplo da amplificação do mRNA da $\beta$-actina nos casos de CEB e tecidos não tumorais adjacentes àles ão (casos de 1 a 9 ) confirmando a reatividade dos tecidos

O NT da amostra de número dois foi utilizada para otimização desta fase e, posteriormente, para controle positivo das reações subseqüentes uma vez que foi seqüenciada e confirmada a presença do transcrito dos três genes. O controle negativo foi constituí do de $25 \mu$ l do "MIX" com ausência do cDNA.

Os resultados das reações foram avaliados em gel de agarose a $1 \%$ (Invitrogen), contendo brometo de ef́ dio e visualizado sob luz UV. O resultado em gel foi documentado fotograficamente com câmara Polaroid e posteriormente digitalizadas e analisadas pelo programa ImageJ 1.29, o qual avalia a intensidade das bandas em pixels. 


\subsubsection{Subclonagem}

Os produtos de amplificação dos três genes foram separadamente inseridos em vetor pCR 2.1 utilizando-se o sistema TOPO TA® Cloning (Invitrogen, Gaithesburg, MD, USA) segundo instruções do fabricante. Foram adicionados em tubo Eppendorf $1 \mu \mathrm{l}$ do inserto (produto do PCR), $1 \mu$ le solução salina (que

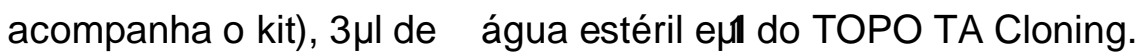

\subsubsection{Transformação do plasmí deo e seqüênciamento}

Após a subclonagem, o "vetor + inserto" foram introduzidos em bactérias $E$. coli fornecidas no Kit One Shot® Chemical Transformation (Invitrogen, Gaithesburg, MD, USA). A este passo chamamos transformação. Trinta $\mu$ das células $E$. coli ficaram incubadas em gelo por 30 minutos com $5 \mu$ do "vetor + inserto", e a seguir sofreram aquecimento rápido deixando-se por 30 segundos em banho-maria, quando então foram adicionados $0,9 \mathrm{ml}$ de meio $\mathrm{SOC}$ com $\mathrm{MgCl}_{2}$ e incubado sob vigorosa agitação a $37^{\circ} \mathrm{C}$ por 1 hora. Usando técnica estéril, 10 a $100 \mu \mathrm{l}$ da solução "vetor+inserto+bactéria" foram transferidos para placas de Petri contendo meio LBAgar com ampicilina ( $1 \mu$ l Ampicilina/ ml de LBAgar) ficando as mesmas incubadas por 18 horas ("overnight") a $37^{\circ} \mathrm{C}$. No dia seguinte, dez colônias bacterianas foram separadamente removidas dessa placa com auxí lio de alça de metálica flambada e 
transferida, uma a uma, para tubos Falcon 5029 contendo $2 \mathrm{ml}$ de meio LB Broth e ampicilina $(75 \mu \mathrm{g} / \mathrm{ml})$ o qual ficou sob vigorosa agitação durante 8 horas a $37^{\circ} \mathrm{C}$.

Após este peń odo de cultivo, $50 \mu$ do caldo foi removido e adicionado a um tubo Eppendorf de $1,5 \mathrm{ml}$ contendo $50 \mu \mathrm{l}$ de água estéril, a mistura foi aquecida a $95^{\circ} \mathrm{C}$ durante 15 minutos, submetida à centrifugação a $10.000 \times \mathrm{g}$ durante 10 minutos. Foi então retirado $1 \mu \mathrm{l}$ do sobrenadante presente no tubo para amplificação por PCR dos genes objetos de estudo desta pesquisa utilizando os iniciadores já citados no Quadro 4.2.

Os produtos de amplificação do tamanho esperado foram tratados com o Kit Exo-Sap ${ }^{\circledR}$ (Invitrogen) seguindo recomendações do fabricante e enviados para seqüenciamento pelo Centro de Estudos Genoma do Instituto de Biociências da USP (IB-USP).

O material seqüenciado foi verificado por "pairwise" BLAST (http://www.ncbi.nlm.nih.gov/blast/bl2seq/bl2.html). O cromatograma sintetizado de cada gene pode ser visualizado em anexo (Anexos C, D e E).

Ao tubo contendo as bactérias transformadas com o vetor e inserto, e que tiveram seqüenciamento confirmado, foi adicionado $3 \mathrm{ml}$ de meio LB Broth e ampicilina $(75 \mu \mathrm{g} / \mathrm{ml})$, ficando este então sob vigorosa agitação durante 8 horas a $37^{\circ} \mathrm{C}$. Após esse peń odo foram adicionados $500 \mathrm{ml}$ do mesmo meio, e novamente incubado nas mesmas condições durante 18 horas.

Posteriormente, uma alí quota da suspensão bacteriana foi retirada, misturada com glicerol na concentração de $6: 1$ e armazenada a $-80^{\circ} \mathrm{C}$ para estoque. $\mathrm{O}$ restante foi transferido para frascos de $250 \mathrm{ml}$ e centrifugado a $4.500 \mathrm{rpm}$ durante 15 minutos, e o corpo de fundo resultante submetido à purificação de DNA através do sistema Wizard® Plus Maxipreps (Promega, Madison WI, USA). O corpo de fundo foi 
dissolvido com a solução de suspensão celular (Tris-HCl 50mM, pH 7,5; EDTA $10 \mathrm{mM}$; RNase A $100 \mu \mathrm{g} / \mathrm{ml})$ e a este volume adicionado solução de lise ( $\mathrm{NaOH}$ 0,2M; SDS 1\%). Quando a solução se tornou clara e viscosa foi juntada ao volume a solução neutralizadora (que acompanha o Kit) e o total centrifugado a 14.000rpm durante 15 minutos à temperatura ambiente (TA). O sobrenadante foi então coletado, adicionado a este isopropanol na concentração de 1:2 e centrifugado novamente a 14.000rpm durante 15 minutos à TA. O corpo de fundo obtido foi dissolvido com $2 \mathrm{ml}$ de tampão TE (Tris-HCl 10mM, pH 7,5; EDTA 1mM) e então acrescido de resina pré-aquecida a $30^{\circ} \mathrm{C}$. A mistura DNA-resina foi então transferida para colunas, acondicionadas a um aparato de vácuo e submetidas a seguinte solução: $\mathrm{NaCl} 85 \mathrm{mM}$; Tris- $\mathrm{HCl} \mathrm{pH} 7,5,8,5 \mathrm{mM}$ e EDTA 2mM. As colunas foram lavadas com álcool $80 \%$ e deixadas secar a vácuo durante 2 minutos. O DNA foi eluí do da coluna com tampão TE, pré-aquecido a $60^{\circ} \mathrm{C}$ e estocado a $-20^{\circ} \mathrm{C}$ por no mí nimo 48 horas. A quantificação do DNA foi obtida por densidade óptica em espectrofotômetro (Beckmann DU-640).

\subsubsection{Preparo das Sondas}

O DNA purificado obtido na fase anterior foi então digerido para linearização a $37^{\circ} \mathrm{C}$ durante 4 a 6 horas em presença das enzimas de restrição planejadas no quadro 3 (na concentração de 15\%) do tampão indicado (na concentração de 10\%) e de água (25\% do total) (Figura 4.3). A transcrição do cDNA em RNA (ribo-sonda) foi efetuada num tubo Eppendorf contento 1\% de DNA linearizado, 40\% de água, 1\% de tampão de transcrição (10X), $1 \%$ de DTT (“Dithiothreitol”), $1 \%$ de 
oligonucleot́ deos marcados com digoxigenina, $0,5 \%$ de inibidor de RNase e $0,5 \%$ de RNA polimerase (Quadro 4.3), durante 2 horas à $37^{\circ} \mathrm{C}$.

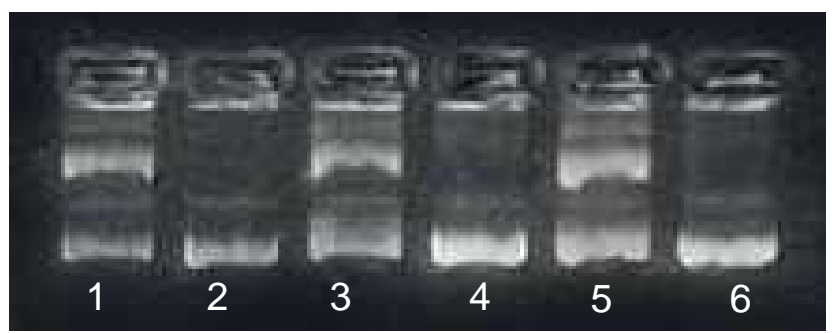

Figura 4.3 -Imagem fotogr áica do resultado obtido após linearização do vetor contendo a seqüência de cDNA dos genes HOXB13 (1 e 2), HHEX (3 e 4) e da ßactina (5 e 6), da esquerda para direita

\begin{tabular}{|c|c|c|}
\hline Gene & $\begin{array}{c}\text { Endonuclease de } \\
\text { Restrição }\end{array}$ & Enzima de Transcrição \\
\hline HOXB13 $\alpha$ & EcoRV & sp6 \\
\hline HOXB13 s & BamH1 & T7 \\
\hline HHEX $\alpha$ & BamH1 & T7 \\
\hline HHEX s & Xba1 1 & Sp6 \\
\hline$\beta$-actina $\alpha$ & BamH1 & T3 \\
\hline$\beta$-actina $s$ & EcoRV & Sp6 \\
\hline
\end{tabular}

$\alpha=$ sonda alfa ou anti-senso, $s=$ sonda senso

Quadro 4.3 - Endonucleases de restrição e enzimas de transcrição utilizadas para fase de lineariza ção e transcrição, respectivamente

A inspeção da sonda de RNA foi efetuada por meio de um gel de $1 \%$ de agarose em TAE contendo Brometo de Et́́ dio na concentração de $10 \mathrm{mg} / \mathrm{ml}$. Antes de adicionada aos "slots" do gel, a sonda foi misturada com $80 \%$ de água e $10 \%$ de tampão de carga. O resultado foi observado em transluminador e documentado em filme polaróide (Figura 4.4). 


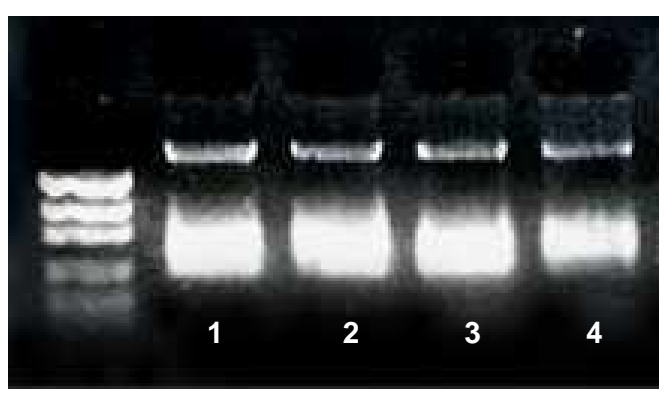

Figura 4.4 - Imagem fotográ́ica do resultado obtido após transcrição das sondas do HOXB13 antisenso (1) e senso (2) e HHEX anti-senso (3) e senso (4) respectivamente

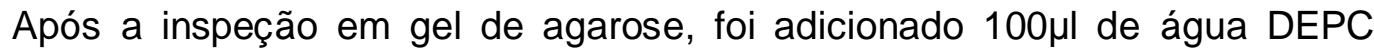
estéril à sonda, $10 \mu \mathrm{l}$ cloreto de lítio $40 \mathrm{mM}, 2 \mu \mathrm{l}$ DNase e $300 \mu \mathrm{l}$ de etanol $100 \%$ e armazenada em freezer $-20^{\circ} \mathrm{C}$ com a finalidade de precipitação.

\subsubsection{Hibridização In Situ}

A técnica de hibridização in situ deve considerar três tipos de controle para garantir a especificidade da reação. Estes controles incluem a reatividade do tecido, integridade da sonda e a especificidade da hibridização (HAMER; HIGGINS, 1985). O controle do tecido verifica a integridade do mRNA (ou cDNA) que pode ser do gene de interesse ou de um genes conhecidamente existente no tecido, como no caso de genes constitutivos (ex. $\beta$-actina - Figura 4.2).

Assim como o RNA, a sonda de RNA (ribossonda) também é instável e sua integridade deve ser verifica após sua confecção através, por exemplo, do gel de agarose ou formaldeí do (Figura 4.4). O propósito do controle da reação de 
hibridização é aumentar a especificidade da ligação sonda-mRNA e diminuir as ligações inespecí ficas. Várias são as formas de controlar a estringência da reação: composição de pares de base da sonda, a natureza e o comprimento da sonda, temperatura, composição da solução de hibridização, particularmente a concentração de cátions monovalentes (na maioria dos casos o sódio) e concentração de formamida e levamisole (SCHWARZACHER; HESLOPHARRISON, 2000).

A porção de cada amostra de tecido reservada para esta técnica foi congelada em criomolde contendo OCT (polí mero inerte) com o aux́ lio de metilbutano e gelo seco para obter a temperatura negativa desejada. Uma vez confeccionados e identificados, os blocos foram seccionados em cortes seriados de $10 \mu \mathrm{m}$ em I âminas silaøajas e, posteriormente, armazenados em freezer $-80^{\circ} \mathrm{C}$.

As lâminas contendo cortes dos tumores foram descongeladas e deixadas para secar antes de serem submetidas à solução de paraformaldeí do $4 \%$ e glutaraldeí do $0.2 \%$ em PBS durante 20 minutos à TA. A seguir, foram transferidas para recipientes (TissueTek, VWR) onde ficavam imersas numa seqüência de $6 \%$ $\mathrm{H}_{2} \mathrm{O}_{2}$ (5 minutos), proteinase $\mathrm{K} 7 \mu \mathrm{g} / \mathrm{ml}$ (Boehringer Mannheim, Indianapolis, IN) por 4 minutos a $37^{\circ} \mathrm{C}$ (concentração, tempo e temperatura otimizados), glicina $2 \mathrm{mg} / \mathrm{ml}$ (10 minutos), e solução de paraformaldeí do $4 \%$ e glutaraldeí do $2 \%$ (20 minutos). Essas soluções foram preparadas em tampão PBT (PBS 10X + 10\% Tween 20/litro de água) e cada incubação foi alternada com lavagens na solução tampão.

As lâminas foram pré-hibridizadas em grupo de quatro em saco plástico selado pelo calor, e imersas na solução de hibridização durante 1 hora a $45^{\circ} \mathrm{C}$ (temperatura otimizada) no forno de hibridização. A solução de hibridização se 
constituiu de formamida 50\%, 5X SSC $(\mathrm{pH} 4,5)$, heparina $50 \mu \mathrm{g} / \mathrm{ml}$, RNA de levedura $50 \mu \mathrm{g} / \mathrm{ml}, 1 \%$ SDS e água para completar $50 \mathrm{ml}$, e foi pré-aquecida a $45^{\circ} \mathrm{C}$.

Antes de ser adicionada à solução de hibridização, a sonda de RNA foi centrifugada a $4^{\circ} \mathrm{C}$ por 15 minutos a $14.000 \mathrm{rpm}$, lavada com etanol $70 \%$ e novamente centrifugada nas mesmas condições. O corpo de fundo ("pellet") foi dissolvido com $40 \mu$ le água de onde foram retirados de $10 \mu$ (concentra ção otimizada) para adição em cada saco plástico contendo as lâminas em solução de hibridização. As lâminas ficaram incubadas nessa solução durante 18 horas, no forno de hibridização a $50^{\circ} \mathrm{C}$.

No dia seguinte as lâminas foram removidas dos sacos plásticos, e lavadas numa solução estringente a $50^{\circ} \mathrm{C}$, com três trocas de 15 minutos em banho-maria sob agitação. Essa solução estava constituí da de formamida a 50\%, 20X SSC (pH 4,5) a $30 \%$, 10X SDS a $10 \%$ e $10 \%$ de água, pré-aquecida a $70^{\circ} \mathrm{C}$. O mesmo procedimento foi repetido para uma solução de menor estringência constituí da de formamida a 50\%, 20X SSC (pH 4,5) a 12\%, e 38\% de água, sob mesma temperatura.

As lâminas, então foram lavadas com uma solução contendo $10 \%$ de TBS ( $\mathrm{NaCl} 0,8 \%, \mathrm{KCl} 0,02 \%, 25 \%$ de $1 \mathrm{M}$ Tris $\mathrm{pH} 7,5$ e 75\% de água), 0,1\% de Tween 20, 0,04\% de levamisole e $80 \%$ de água (TBST). Em seguida foram imersos em solução de TBST e soro fetal bovino a 10\% durante 1 hora à temperatura ambiente para bloqueio de ligações inespecí ficas.

Após o bloqueio, as lâminas foram novamente colocadas em grupo de quatro num saco plástico selado pelo calor, e imersas numa solução contendo o anticorpo anti-digoxigenina (DIG/AP Rabbit F (ab'), Dako A/S, Denmark) na concentração de 
1:2.000 e soro fetal bovino a 1:300 onde ficaram durante 18 horas a $4^{\circ} \mathrm{C}$ sob agitação.

Terminada a incubação com o anticorpo, as lâminas foram lavadas extensivamente com TBST ( 3 banhos de 5 minutos e 3 banhos de 30 minutos) e então incubadas em 3 banhos de NTMT ( $\mathrm{NaCl} 5 \mathrm{M}$ à $2 \%, 2 \mathrm{M}$ Tris- $\mathrm{HCl}$ pH 9,5, $\mathrm{MgCl}_{2}$ $2 \mathrm{M}$ à 2,5\%, Tween 20 à $1 \%$ e levamisole à $0,048 \%$ em água) por 10 minutos cada. $\mathrm{A}$ detecção da reação deu-se na ausência de luz, com NBT $(75 \mathrm{mg} / \mathrm{ml}$ em dimetilformamida $30 \%$ ) e BCIP (50mg/ml em água) misturados com NTMT na concentração de 1:300 e 1:380 respectivamente, durante o tempo necessário para visualização do sinal (tempo otimizado entre 48 a 72 horas). A reação de revelação foi bloqueada com PBT e EDTA $(0,5 \mathrm{M})$ na proporção de 1:500. O resultado da reação foi analisado e documentado fotograficamente em um microscópio Zeiss, Jenapol. Este método foi previamente descrito por Wu e Oh (1996).

\subsection{Análise dos resultados}

A presença e ní vel de amplificação, através da técnica de PCR, do transcrito dos genes HOXB13 e HHEX no grupo dos TTs foi correlacionado com a amplificação do NT, com a idade do paciente, o grau histológico do tumor, classificação UICC, estadiamento pT, estadiamento pN, espessura do tumor, envolvimento com estruturas adjacentes, invasão vascular e perineural.

Os resultados obtidos através da técnica de PCR foram analisados estatisticamente com o auxílio dos softwares StatSoft Statistica versão 6.0 e SAS 
System for Windows versão 8.0 com um nível de significância de 0,05 . Os testes realizados foram escolhidos conforme Zar (1999) e Tabachnick e Fidell (1996).

Os resultados obtidos através da técnica de ISH foram avaliados morfologicamente, através de microscopia de luz, considerando o padrão de expressão do transcrito nos diversos tecidos contidos nas amostras de TT e NT. A análise do padrão de expressão do transcrito é, de certa forma, subjetiva, pois segue uma avaliação qualitativa da presença do mRNA do gene analisado nos vários tecidos que compõem o corte histológico. Assim, dentro de um mesmo corte histológico pode-se verificar uma variação de tons azulados (proporcionado pelo cromógeno NBT-BCIP) passando por intenso azul, tênue, ou apenas um azulado inespecí fico que constitui um fundo de precipitado do cromógeno. Toda estrutura que se destacou a partir deste "fundo" foi considerada marcada ou positiva. 


\section{RESULTADOS}

\subsection{Caracteń sticas da amostra}

A amostra de 30 pacientes portadores de carcinoma epidermóide de boca estava composta predominantemente por homens $(63,3 \% ; n=19)$, apresentando média de idade de 56,1 anos, estando a maioria situada nas quinta, sexta e sétima décadas de vida (Gráfico 5.1), de etnia branca (80\%; $n=24)$ (Gráfico 5.2). A maioria dos tumores estava localizada na língua $(80 \%, n=24)$, seguido do lábio $(10 \%, n=3)$ e assoalho bucal $(10 \%, n=3$ ) (Gráfico 5.3). Espessura tumoral maior que $1 \mathrm{~cm}$ foi verificada em $58,3 \%(n=14)$ dos casos.

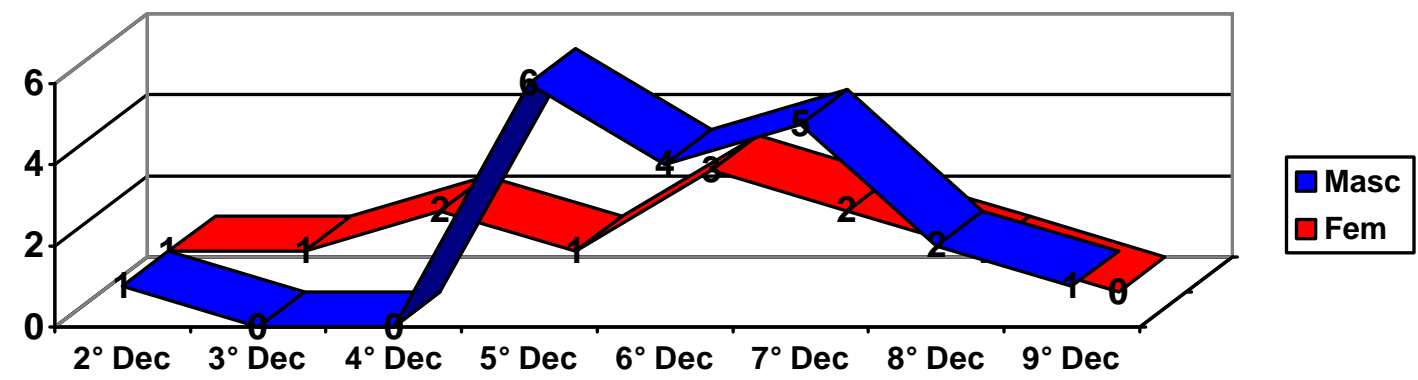

Gráico 1 -Distribuição da incid ência de câncer bucal segundo sexo e década de vida

Para os pacientes desta amostra, com dados informados no quadro 4.1 (Capí tulo de Material e Métodos item 4.3), foi observado que o estadiamento pós- 
operatório TNM (pTNM) foi de quatro casos em pT1(2N0, 1N1, 1N2a)M0, nove casos em pT2(6N0, 2N1, 1N2a)M0, um caso em pT3(N2)M0 e 13 casos em pT4(2NX, 6N0, 1N1, 2N2, 2N3)M0. Com respeito à classificação UICC, 33,3\% (n = 9) dos casos eram iniciais ou precoces e 66,7\% ( $n=18)$ eram avançados (Gráfico 5.4). A gradação histológica dos tumores mostrou que $56,6 \%(n=13)$ dos tumores eram moderadamente diferenciados, $34,7 \%(n=8)$ bem diferenciados e $8,7 \%(n=$ 2) pouco diferenciados.
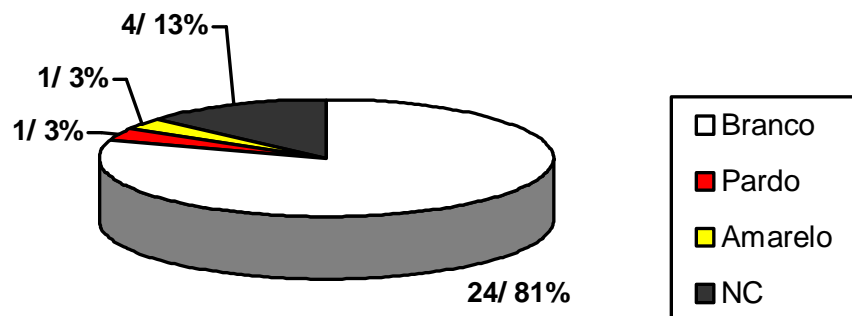

Gráfico 5.2 - Distibuição do câncer bucal segundo o grupo énico (NC = Não consta).

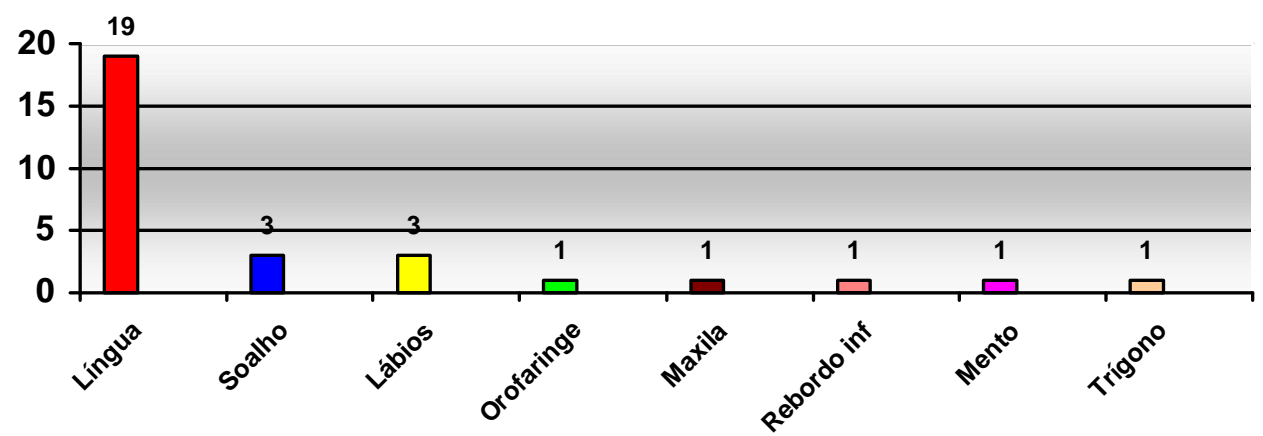

Gr áico 5.3 - Distribu ção do câncer bucal segundo a localiza ção 


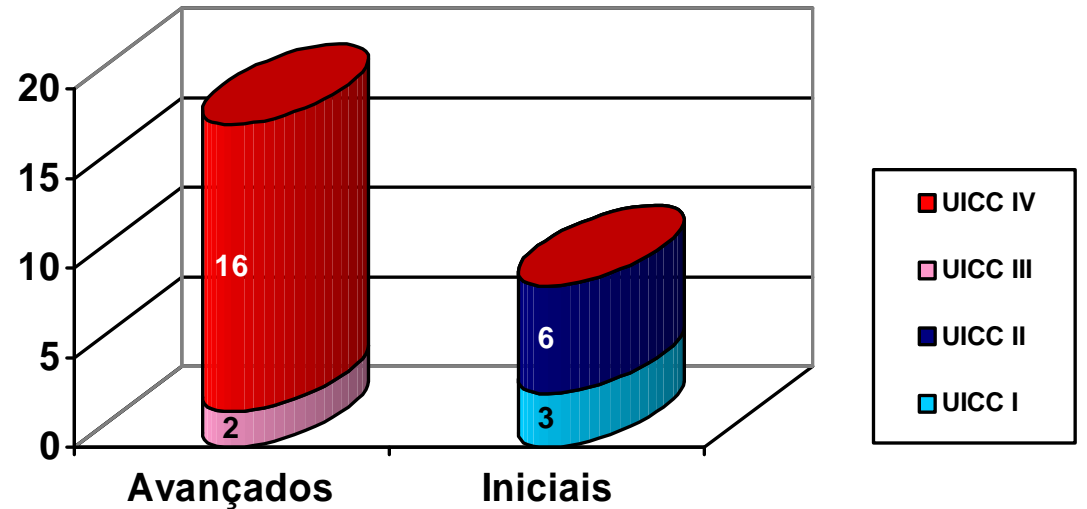

Gráfico 5.4 - Distribuição do câncer de boca segundo classificação UICC, totalizando 9 casos iniciais e 18 avan çados. Tr ês casos não constavam os dados

\subsection{RT-PCR}

\subsubsection{HOXB13}

Dos 30 pacientes selecionados para o estudo, apenas 22 foram incluí dos por possuí rem cDNA do NT e do TT pareados. A presença do transcrito do gene HOXB13 foi verificada em $68,2 \%$ dos NTs e $77,3 \%$ dos TTs. Na Figura 5.1 podem ser verificados exemplos de casos amplificados por RT-PCR nas amostras NT e TT de cada paciente.

Apesar de diferentes intensidades de bandas de amplificação dos transcritos do gene HOXB13 entre o NT e o TT do mesmo paciente terem sido detectadas através do software ImageJ $\mathrm{NIH}$, nenhuma diferença estat́ stica foi observada entre os dois grupos ( $p=0,445982$; teste de Wilcoxon). 
Nenhuma relação estatisticamente significante foi verificada entre a amplificação do transcrito do HOXB13 nos espécimes de tumor e a idade do paciente ( $p=0,350256$; coeficiente de correlação de Spearman), o grau histológico ( $p=0,1023$; teste de Kruskal-Wallis), envolvimento de tecidos adjacentes ( $p=$ 0,158562; Teste de Mann-Whitney), classificação UICC ( $p=0,9453$; teste de MannWhitney), estadiamento pT ( $p=0,3504$; teste de Kruskal-Wallis) e pN ( $p=0,944699$; teste t de Student).

Entretanto, a análise estatí stica mostrou existir uma correlação positiva entre a presença do transcrito no tumor e a espessura tumoral ( $p=0,023830$; coeficiente de correlação de Spearman), a invasão perineural ( $p=0,000$; teste t de Student), e a invasão vascular ( $p=0,0015$; teste t de Student). 


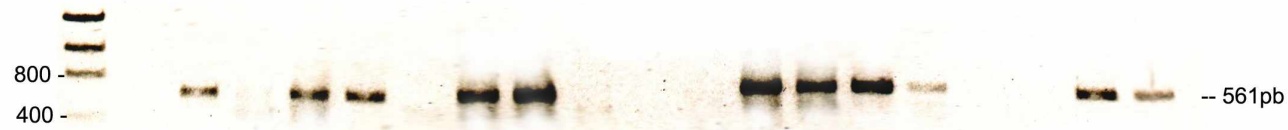

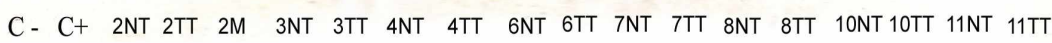

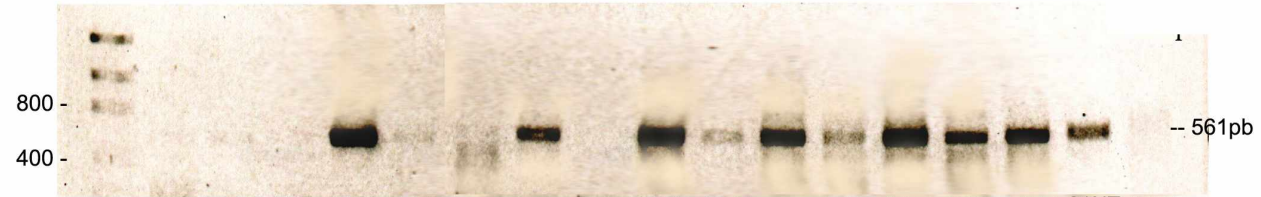

12NT 12TT 13NT 13TT 13M 14NT 14TT 15NT 15TT 16NT 16TT 17NT 17TT 18NT 18TT 21NT 21TT

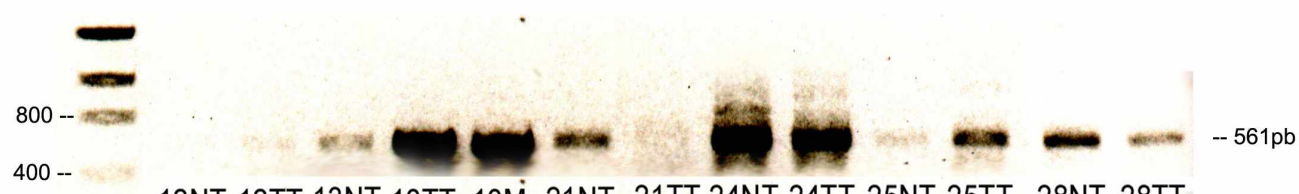

12NT 12TT 13NT 13TT 13M 21NT 21TT 24NT 24TT 25NT 25TT 28NT 28TT

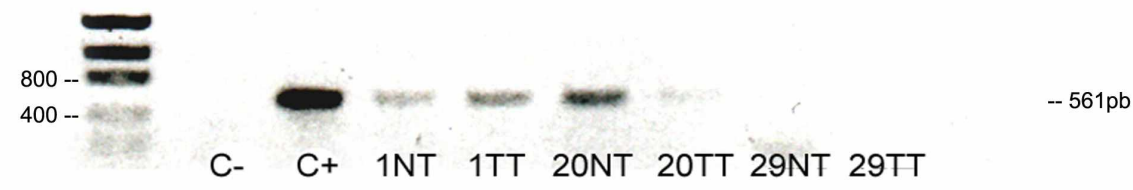

Legenda: $\mathrm{pb}=$ pares de base, $\mathrm{C}-=$ controle negativo, $\mathrm{C}+=$ controle positivo

Figura 5.1 - Gel de agrose 1\% mostrando exemplos de amplificação dos transcritos do gene HOXB13 por RT-PCR nos casos de carcinoma epidermóide bucal (TT) e tecidos não tumoral (NT) 
O Quadro 5.1 mostra resumidamente a relação entre a expressão do transcrito do gene HOXB13 no TT e os fatores prognósticos clí nicos analisados estatisticamente.

\begin{tabular}{|l|l|l|}
\hline Fatores Progn ósticos & $\begin{array}{l}\text { Relação } \\
\text { estatística }\end{array}$ & Teste aplicado \\
\hline Idade & Ausente & $\begin{array}{l}\text { Coeficiente de correlação de Spearman } \\
(p=0,35)\end{array}$ \\
\hline Gradação histol ógica tecidos & Ausente & Teste de Kruskal-Wallis $(p=0,10)$ \\
\hline $\begin{array}{l}\text { Envolvimento de } \\
\text { adjacentes }\end{array}$ & Ausente & Teste de Mann-Whitney $(p=0,15)$ \\
\hline Estadiamento $p T$ & Ausente & Teste de Kruskal-Wallis $(p=0,35)$ \\
\hline Estadiamento pN & Ausente & Teste t de Student $(p=0,94)$ \\
\hline Classificação UICC & Ausente & Teste de Mann-Whitney $(p=0,94)$ \\
\hline Espessura tumoral & Presente & $\begin{array}{l}\text { Coeficiente de correlação de Spearman } \\
(p=0,023)\end{array}$ \\
\hline Invasão perineural & Presente & Teste t de Student $(p=0,0)$ \\
\hline Invasão vascular & Presente & Teste t de Student $(p=0,0015)$ \\
\hline
\end{tabular}

Quadro 5.1 -Relação estatística entre a presen ça do transcrito do gene HOXB13 nos TT e os fatores prognósticos clínicos

\subsubsection{HHEX}

Dos 30 pacientes selecionados para o estudo, apenas 21 foram incluí dos por possuí rem cDNA do NT e do TT pareados. A presença do transcrito do gene HHEX foi verificada em $47,6 \%$ dos NTs e $57,1 \%$ dos TTs da amostra. Na Figura 5.2 podem ser encontrados exemplos dos produtos amplificados nas amostras de NT e TT de cada paciente.

Apesar de diferentes intensidades de bandas de amplificação dos transcritos o gene HHEX entre a amostra de NT e o TT do mesmo paciente terem sido detectadas através do software Image $\mathrm{NIH}$, nenhuma diferença estatí stica foi observada entre os dois grupos ( $p=0,1627$; Wilcoxon' s test). 

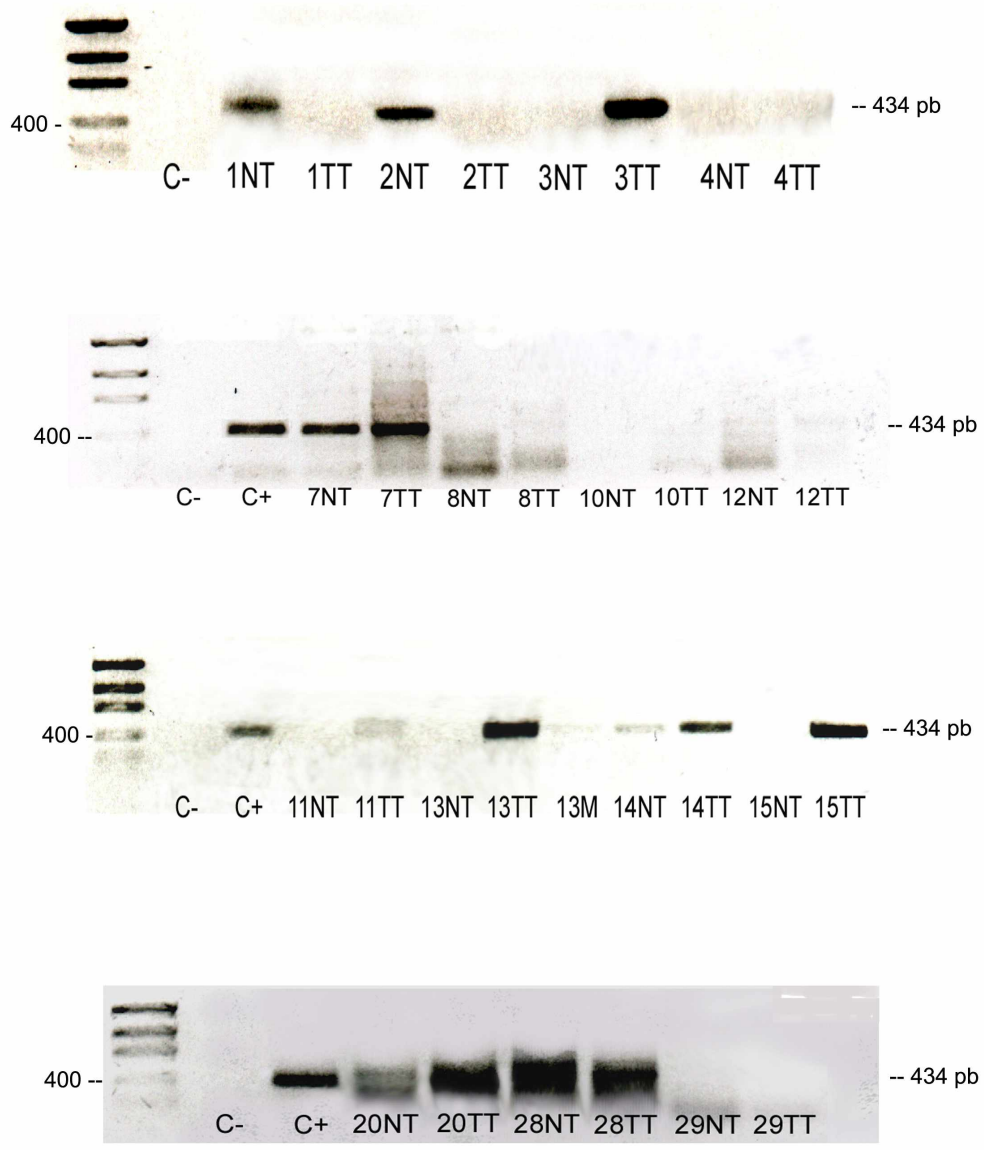

Legenda: $\mathrm{pb}=$ pares de base, $\mathrm{C}-=$ controle negativo, $\mathrm{C}+=$ controle positivo

Figura 5.2 - Gel de agarose 1\% mostrando exemplos de amplificaçao dos transcritos do gene HHEX por RT-PCR nos casos de carcinoma epidermóide bucal (TT) e tecido não tumoral (NT) 
Nenhuma relação estatí stica foi verificada entre a amplificação do transcrito do HHEX e o grau histológico ( $p=0,74$; teste de Kruskal-Wallis), a classificação UICC ( $p=0,2250$; teste de Mann-Whitney), a espessura tumoral $(p=0,76$; coeficiente de correlação de Spearman), a invasão perineural ( $p=0,90$; teste t de Student), estadiamento $\mathrm{pN}(\mathrm{p}=0,17$; teste t de Student) e o estadiamento $\mathrm{pT}(\mathrm{p}=$ 0,$8651 ;$ ANOVA).

Entretanto, a análise estat́ stica mostrou existir uma correlação inversa entre a presença do transcrito no tumor e a idade do paciente ( $p=0,046$; coeficiente de correlação de Spearman) e uma correlação positiva com o envolvimento de tecidos adjacentes ( $p=0,0059$; teste $t$ de Student) e a invasão vascular ( $p=0,001$; teste t de Student).

O Quadro 5.2 demonstra resumidamente a relação entre a expressão do transcrito do gene HHEX no TT e os fatores prognósticos clí nicos analisados estatisticamente.

\begin{tabular}{|c|c|c|}
\hline Fatores Prognósticos & $\begin{array}{l}\text { Rela ção } \\
\text { estatística }\end{array}$ & Teste aplicado \\
\hline Idade & $\begin{array}{l}\text { Presente } \quad \text { (rela ção } \\
\text { inversa) }\end{array}$ & $\begin{array}{l}\text { Coeficiente de correlação de Spearman } \\
(p=0,046)\end{array}$ \\
\hline Invasão vascular & Presente & Teste $t$ de Student $(p=0,001)$ \\
\hline $\begin{array}{l}\text { Envolvimento de tecidos } \\
\text { adjacentes }\end{array}$ & Presente & Teste t de Student $(p=0,0059)$ \\
\hline Grada ção histol ógica & Ausente & Teste de Kruskal-Wallis $(p=0,74)$ \\
\hline Estadiamento pT & Ausente & Teste ANOVA $(p=0,86)$ \\
\hline Estadiamento pN & Ausente & Teste $t$ de Student $(p=0,17)$ \\
\hline Classifica ção UICC & Ausente & Teste de Mann-Whitney $(p=0,22)$ \\
\hline Espessura tumoral & Ausente & $\begin{array}{l}\text { Coeficiente de correlação de Spearman } \\
(p=0,76)\end{array}$ \\
\hline Invasão perineural & Ausente & Teste $\mathrm{t}$ de Student $(\mathrm{p}=0,90)$ \\
\hline
\end{tabular}

Quadro 5.2 - Relação estatística entre a presença do transcrito do gene HHEX nos TT e os fatores prognósticos clínicos 


\subsection{Hibridização in situ (ISH)}

De forma a facilitar a descrição morfológica dos achados da $\mathrm{ISH}$, os resultados foram considerados e descritos por tipo de tecido (TN ou TT) começando pela descrição das amostras de TT, já que constitú ram o principal objetivo do presente estudo.

\subsubsection{Tecido tumoral}

\subsubsection{HOXB13}

Vinte e cinco cortes pareados de TT e NT do mesmo paciente constituí ram a amostra para análise do transcrito do gene HOXB13. Nem sempre as amostras submetidas à reação de ISH estavam pareadas com as amostras amplificadas por RT-PCR. Algumas amostras foram excluí das por falta de pareamento ou reatividade duvidosa da sonda para o gene da $\beta$-actina.

Os cortes histológicos de TT corados em H.E. estavam constituí dos de fragmento de neoplasia de origem epitelial exibindo graus variados de invasão no tecido conjuntivo subjacente. As células neoplásicas estavam organizadas em ilhotas ou cordões, nas neoplasias bem ou moderadamente diferenciadas, e exibiam graus variados de disqueratose e formação de pérolas córneas. As neoplasias 
pouco diferenciadas exibiam um padrão de organização celular mais disperso onde as células estavam organizadas em pequenos grupos de três ou quatro células ou mesmo localizadas isoladas no estroma neoplásico freqüentemente invadindo tecidos adjacentes presentes nas camadas mais profundas. Graus vaiados de pleomorfismo celular, mitoses at́ picas e hipercromasia nuclear estavam presentes. O estroma das lesões estava constituí do de tecido conjuntivo denso exibindo quantidades variadas de vasos sanguíneos e infiltrado inflamatório mono ou polimorfonuclear.

Após a realização da técnica de $\mathrm{ISH}$, foi verificado que a expressão dos transcritos nos cortes de TT estava presente no epitélio neoplásico de superfí cie e nas ilhotas epiteliais, apresentando graus variados de contraste com o tecido conjuntivo subjacente. As ilhotas neoplásicas exibiram forte presença do transcrito do HOXB13 (Figuras 5.3A a 5.3D). Neoplasias moderadamente e pouco diferenciadas também exibiram presença do transcrito nas células neoplásicas (Figuras 5.3E a 5.3H). O estroma que circundava as ilhotas neopásicas estava negativo, exceto pelos componentes endoteliais.

Quando presentes, o endotélio vascular assim como os feixes nervosos, apresentaram-se positivos. Os ácinos serosos das glândulas salivares acessórias foram negativos. Entretanto seus respectivos ductos e os ácinos mucosos exibiram a presença do transcrito. O estroma glandular foi negativo, exceto pelos componentes endoteliais ou quando invadido por células neoplásicas (Figura 5.3H). 
Figura 5.3 - Fotomicrografias ilustrando padrão de express ão do gene HOXB13 em carcinoma epidermáde de boca. Em A e $\mathbf{C}$ observa-se fragmentos de carcinoma epidermáde bem diferenciado exibindo células neoplásicas organizadas em ilhotas e por vezes formando pérola cớnea em seu interior (HE, 200X). Em B o mesmo corte da figura A submetido à técnica de ISH onde se observa a presença dos transcritos do HOXB13 nas ilhotas neoplásicas (NBT/BCIP, 200X); em D as cálulas neoplásicas bem diferenciadas expressam fortemente o transcrito enquanto que as pérolas cớneas exibem apenas precipitado (NBT/BCIP, 100X). Em E observa-se fragmento de CEB moderadamente diferenciado com cálulas neoplásicas organizadas em ilhotas e cordães e estroma tumoral constituído de tecido conjuntivo denso com infiltrado inflamatớio moderado (HE, 100X); em F detalhe do mesmo corte anterior submetido à técnica de ISH e exibindo céulas neopl ásicas positivas para o HOXB13 (NBT/BCIP, 200X), nota-se que, quando comparado aos cortes de CEB bem diferenciados, esta sinalização é ligeiramente mais fraca. Em G, fragmento de glândula salivar acess ớia comprometida por CEB pouco diferenciado onde se observa céulas neoplásicas envolvendo a estrutura glandular (HE, 400X); em H mesmo corte que o anterior submetido à técnica de ISH e exibindo c éulas neopl ásicas e ductos glandulares positivos para os transcritos do gene HOXB13 (NBT/BCIP, 400X). 

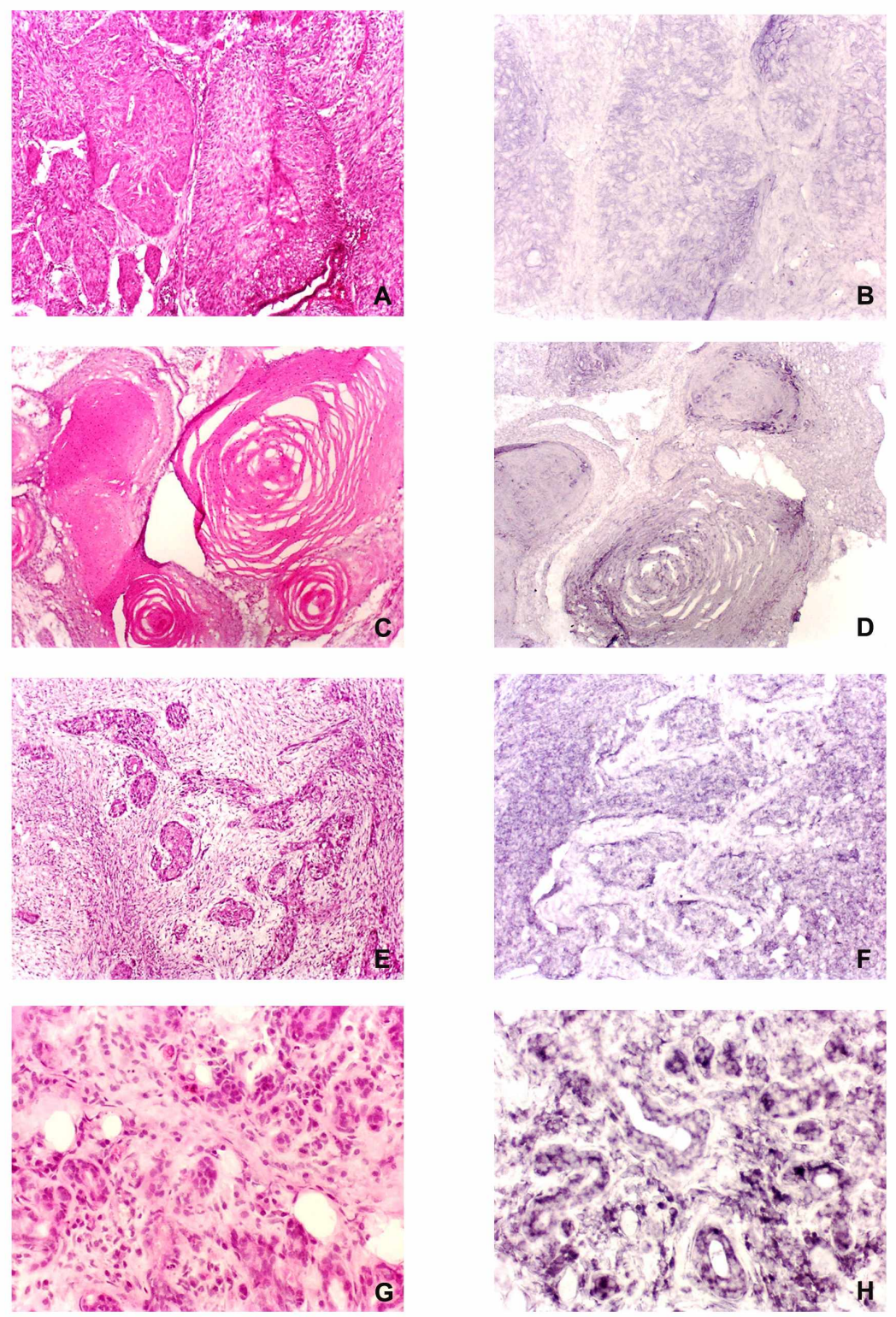

Figura 5.3 


\subsubsection{HHEX}

Vinte e um pares de cortes de TT e NT foram avaliados. Pelo mesmo motivo do gene anterior, nem sempre as amostras submetidas à reação de ISH estavam pareadas com as amostras amplificadas por RT-PCR. Os cortes histológicos corados em H.E. seguem a mesma descrição morfológica apresentada para o gene HOXB13.

Nos cortes de TT, a presença dos transcritos do gene HHEX exibiu um padrão de expressão considerado tênue e consistente. O Epitélio de superfície quando alterado exibiu expressão mais forte que o tecido normal adjacente, o qual foi negativo. As ilhotas neoplásicas, em especial, exibiram forte expressão do transcrito destacando-se do estroma lesional, levemente positivo nos cortes de tecido não tumoral. Graus variados de intensidade da presença do transcrito foram observados. Tanto nos CEB bem diferenciado (Figuras 5.4A a 5.4D) quanto em CEBs moderadamente (Figuras 5.4E e 5.4F) e pouco diferenciados (Figuras 5.4G e $5.4 \mathrm{H})$.

Os componentes endoteliais e inflamatórios do estroma estavam positivos, mas, os tecidos musculares e vasos de maiores calibres estavam negativos. 
Figura 5.4 - Fotomicrografias ilustrando padrão de expressão do gene HHEX em carcinoma epiderm âde de boca. Em $\mathbf{A}$ e $\mathbf{C}$ observa-se fragmentos de carcinoma epidermáde bem diferenciado exibindo céulas neopl ásicas organizadas em ilhotas e por vezes formando péola cớnea em seu interior (HE, 200X). Em B o mesmo corte da figura $A$ submetido à técnica de ISH onde se observa a presença dos transcritos do HHEX nas ilhotas neoplásicas delimitando estruturas celulares no centro das ilhotas, as quais se destacam do estroma (NBT/BCIP, 400X); em D as cáulas neoplásicas bem diferenciadas expressam fortemente o transcrito, células inflamatớias também se mostram positivas $\left({ }^{*}\right)$ (NBT/BCIP, 200X). Em E observa-se fragmento de CEB moderadamente diferenciado exibindo uma ilhota neoplásica e céulas dispersas no estroma tumoral (HE, 200X); em $\mathbf{F}$ detalhe do mesmo corte anterior submetido à téenica de ISH e exibindo c éulas neopl ásicas positivas para o HOXB13 (*) (NBT/BCIP, 400X), nota-se que, quando comparado aos cortes de CEB bem diferenciados, esta sinalização é ligeiramente mais fraca. Em G, fragmento de CEB pouco diferenciado exibindo cäulas com maior padrão de pleomorfismo e hipercromasia nuclear organizadas em pequeno conjuntos e dispersas no estroma tumoral (HE, 400X); em $\mathbf{H}$ mesmo corte que o anterior submetido àtécnica de ISH e exibindo c éulas neoplásicas $\left.{ }^{*}\right)$ com padrão de expressão mais fraco para os transcritos do HHEX quando comparados com os cortes anteriores (NBT/BCIP, 400X). 

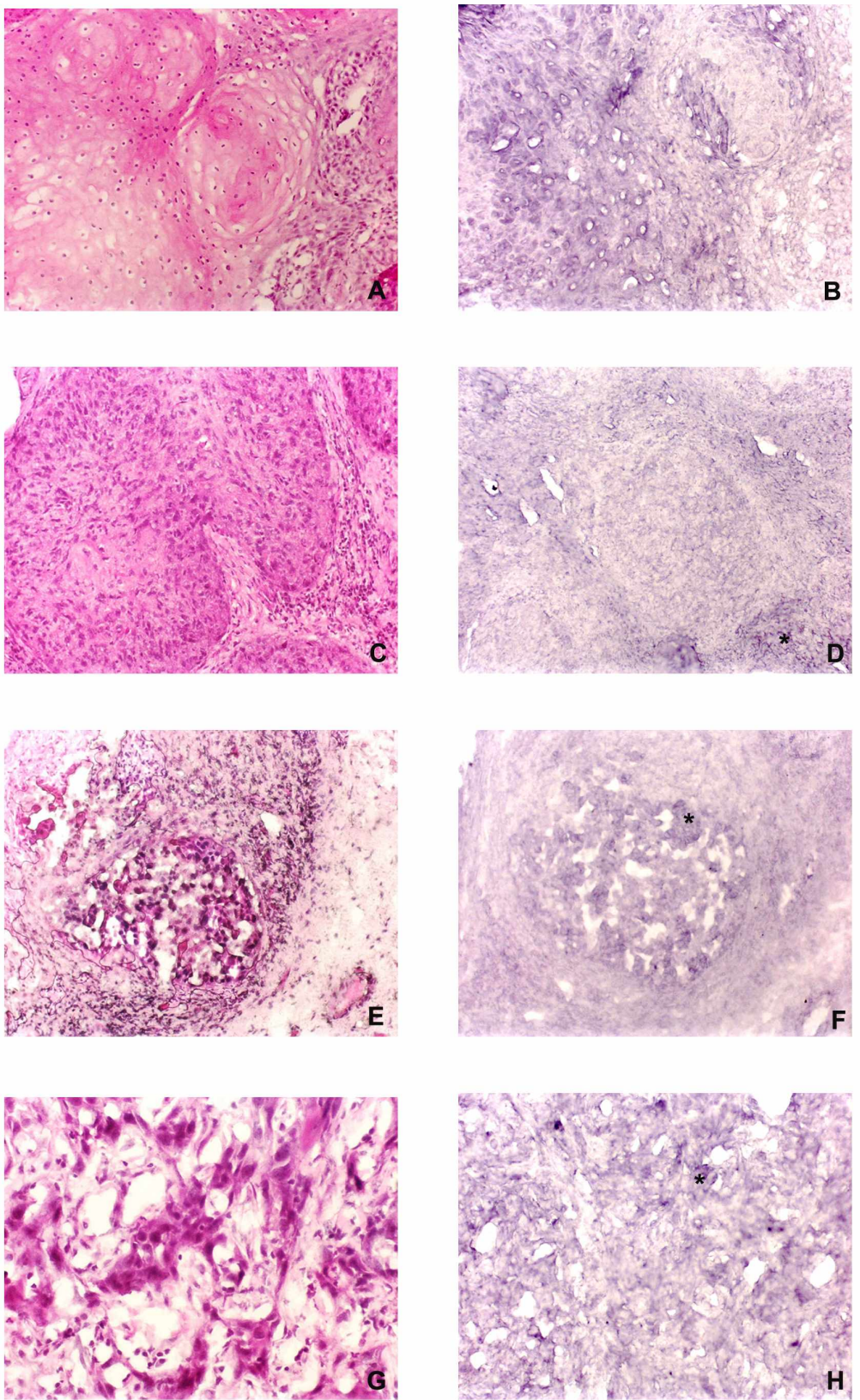

Figura 5.4 


\subsubsection{Tecido não tumoral}

\subsubsection{HOXB13}

Os cortes histológicos corados em H.E. de NT estavam constituí dos de fragmento de mucosa, ou semimucosa, por vezes queratinizado e, alguns cortes exibindo acantose com algum grau de atipia epitelial devido à proximidade com o tumor. A lâmina própria estava constituí da de tecido conjuntivo denso exibindo quantidades variadas de vasos sanguí neos e nervos e, em camadas mais profundas tecidos muscular, adiposo ou glandular. Muitos cortes histológicos estavam constituí dos apenas de fragmentos de tecido muscular ou de glândulas salivares acessórias com caracteń sticas usuais de normalidade, ou exibindo células inflamatórias em graus variados.

De forma geral, foi verificado que o padrão de expressão do transcrito do gene HOXB13 é intenso na maioria dos tecidos analisados, porém com variações de intensidade de expressão para o mesmo tecido em diferentes amostras.

A técnica de ISH exibiu o epitélio pavimentoso estratificado de superfí cie da mucosa ou derme com tênue marcação, sendo a presença dos transcritos mais intensa delimitando grupos de células da camada espinhosa e nas células mais próximas da camada de paraqueratina. Entretanto, nos cortes que apresentaram áreas proliferativas exibindo áreas de acantose ou atipias de graus variados, a presença do transcrito estava mais intensa (Figuras 5.5A e 5.5B). 
O limite epitélio-conjuntivo apresentou-se nítido sugerindo presença do transcrito nas células basais ou lâmina basal dos cortes histológicos (Figuras 5.5A e 5.5B). A lâmina própria, quando comparado com os outros tecidos presentes, apresentou-se negativa para presença do transcrito do gene HOXB13. A musculatura estriada esquelética presente em planos mais profundos exibiu fibras bem delimitadas, sugerindo positividade no estroma da região adjacente às fibras, que estavam negativas.

Freqüentemente o endotélio vascular apresentou-se positivo, principalmente nos vasos de menor calibre (Figuras 5.5B e 5.5E), assim como os feixes nervosos (Figuras 5.5D a 5.5F).

Os ácinos serosos das glândulas salivares acessórias foram negativos. Entretanto seus respectivos ductos e os ácinos mucosos exibiram a presença do transcrito (dados não mostrados). O estroma glandular foi negativo, exceto pelos componentes endoteliais.

Alguns cortes histológicos exibiram fragmentos de derme onde se podia verificar a presença de anexos cutâneos os quais apresentaram-se positivos para presença do transcrito (dados mostrados adiante na Figura 5.6).

\subsubsection{HHEX}

Os cortes histológicos corados em H.E. seguem a mesma descrição morfológica apresentada para o gene HOXB13. 
Figura 5.5 - Microfotografias ilustrando o padrão de expressão dos transcritos dos genes HOXB13 (de A a F) e HHEX (de G a L) em NT. Em A, fragmento de mucosa revestido por epit Aio pavimentoso estratificado e exibindo acantose e exocitose com diversos vasos sanguíneos na lâmina própria (HE, 100X); em B mesmo corte que o anterior submetido à técnica de ISH e exibindo forte sinaliza ção dos transcritos do gene HOXB13 na regi ão mais acantáica do epit aio e nos capilares da lâmina própria (NBT/BCIP, 200X). Em C, Fragmento de submucosa exibindo glândula salivar acessớia, feixes nervosos, vasos e músculo (HE, 100X); em D mesmo corte que em C submetido à técnica de ISH e exibindo expressão do HOXB13 nos feixes nervosos, parede de vaso e glândula mucosa (NBT/BCIP, 100X); em E detalhe em maior aumento de vaso sang üneo na figura $D$ (400X); em $\mathbf{F}$ detalhe em maior aumento de feixe nervoso presente na figura $D$ (400X). Em G, fragmento de submucosa constituída de tecido conjuntivo denso sediando cadulas inflamatớias e exibindo vasos sangüneos ectásicos, e, no lado direito, corte transversal de ducto glandular (HE, 100X); em $\mathbf{H}$ detalhe em maior aumento do corte anterior ilustrando c elulas inflamat ớias no interior de vaso $\left(^{*}\right)$ positivo para o transcrito do HHEX, incluindo a paredes dos vasos I (NBT/BCIP, 400X). Em J, fragmento de gl ândula salivar acessória, vasos e ductos exibindo características usuais de normalidade (HE, 400X); em L mesmo corte que o anterior desta vez submetido à téenica de ISH onde épossível verificar a presença dos transcritos do gene HHEX nos ácinos mucosos e respectivos ductos (NBT/BCIP, 400X). 

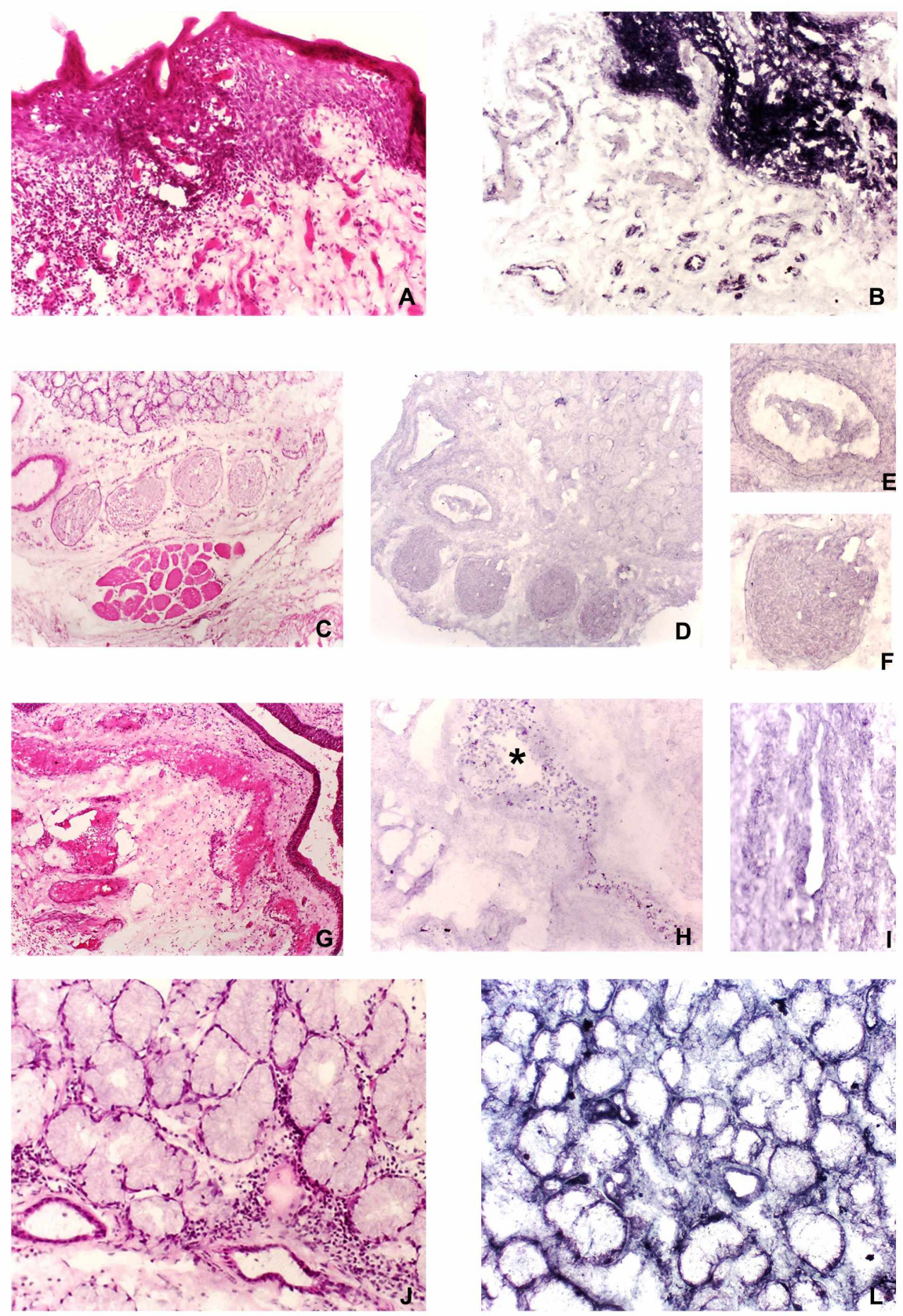

Figura 5.5 
A técnica de ISH revelou que a presença do transcrito do gene HHEX nos cortes de tecido NT foi, de forma geral, tênue, porém invariável. Apesar de uma positividade dispersa, foi possí vel verificar áreas com maior expressão do mRNA do HHEX.

O epitélio pavimentoso estratificado da superfície, exibindo atrifia ou acantose, mostrou menor presença do transcrito, ou estava negativo, quando comparado com a lâmina própria. Porém, foi possí vel verificar células da camada espinhosa com membrana citoplasmática bem delimitada. Células basais estavam negativas, dificultando e percepção do limite epitélio - conjuntivo, exceto quando havia presença de pigmentação melânica fisiológica nestas células as quais permitiam a delimitação o epitélio mesmo sendo negativas para presença do transcrito.

A lâmina própria exibiu maior expressão dos transcritos quanto comparada com o epitélio de superfí cie. Células endoteliais e células inflamatórias exibiram maior intensidade de expressão (Figuras 5.5G a I). Os fragmentos contendo músculo estriado esquelético, nervo e vasos ou arteń olas de grandes calibres se apresentaram negativos.

As glândulas salivares acessórias exibiram dois padrões de expressão. Glândulas salivares serosas foram negativas, mas, seus respectivos ductos foram positivos (Figuras 5.5J e 5.5L) e as estruturas acinares das glândulas mucosas e ductos excretores revelaram diferentes intensidades da presença de transcrito, por vezes mais intenso e por vezes mais tênue.

O epitélio pavimentoso estratificado, por sua vez, quando exibiu graus variados de acantose e/ou atipias apresentou maior intensidade de expressão dos transcritos do gene HHEX quando comparada ao epitélio normal de superfície preservado (dado não mostrado). 
Os controles negativos submetidos à técnica de ISH com a sonda senso não exibiram marcação para nenhum dos dois genes estudados (Figura 5.6). 
Figura 5.6 - Fotomicrografias de cortes submetidos à técnica de ISH com a sonda senso como controle negativo para os genes HOXB13 ( Figuras A, C e E) e HHEX (Figura G). Verifica-se que os cortes das figuras A, C, E e G não exibem qualquer presença de transcrito de seus respectivos genes. Os cortes B, D, F e H são controles positivos das imagens contra-laterais (submetidos à reação com sonda anti-senso ou d). Em B presença do transcrito do gene HOXB13 em epitáio de fragmento NT exibindo maior expresão na área mais acantáica e no endotéio da lâmina própria (NBT/BCIP 200X); em D outro padr ão de express ão para o transcrito do gene HOXB13 em epit बio normal, nota-se que há uma maior sinalização no epit áio quando comparado ao conjuntivo da lâmina própria subjacente (NBT/BCIP, 200X); em F forte presença do transcrito do HOXB13 em tricócitos e bulbo do folículo piloso (NBT/BCIP, 200X). Em H tênue expressão do HHEX em cortes de NT, verifica-se que o conjuntivo exibe tênue positividade (com maior concentração no endot éio *) quando comparado com o epit đio normal supra-localizado (NBT/BCIP, 100X); seu controle negativo contralateral (G) está negativo para as mesmas regi œ̃es descritas. 

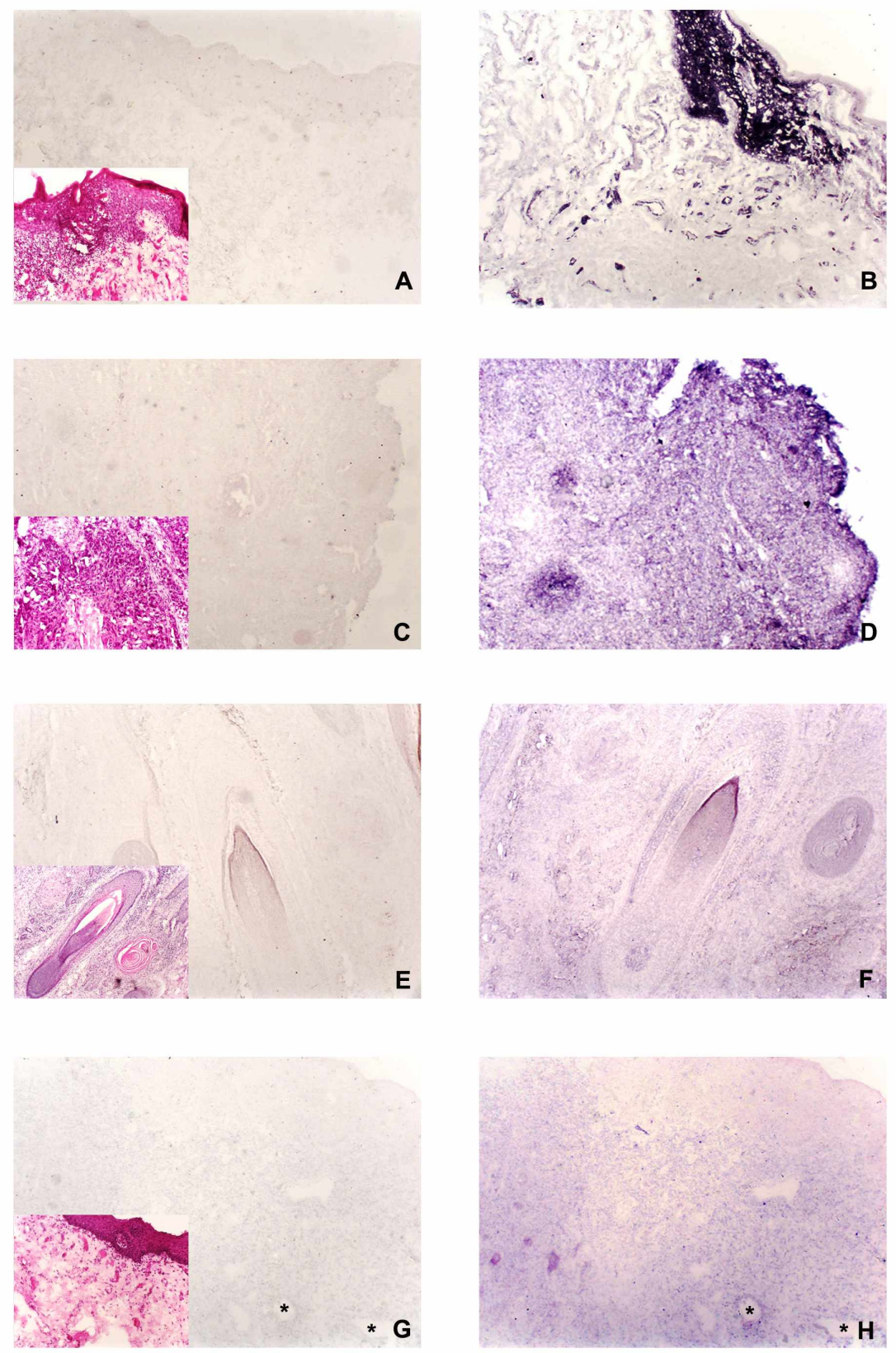

Figura 5.6 


\section{DISCUSSÃ O}

Desde que o câncer de boca é considerado um problema de saúde pública no Brasil, mais atenção tem sido direcionada para sua resolução. A incidência de carcinoma epidermóide bucal no nosso paí s é alta, e os resultados deste trabalho concordam com o perfil epidemiológico descrito dos acometidos por esta neoplasia, sendo a maioria deles do sexo masculino, entre a quinta e sétima décadas de vida, e pertencentes ao grupo étnico branco. Dados nacionais com descrições de amostras maiores relatam a 6 ${ }^{\text {a }}$ década de vida como a mais afetada (DURAZZO et al., 2001; FRANCO et al., 1989) enquanto a literatura internacional, apesar de perfis epidemiológicos similares, antecipa a maior incidência para a quinta década de vida, provavelmente devido a particularidades ambientais, como maior consumo de álcool ou das diversas formas de tabaco, ou mesmo hábitos alimentares (KRAMER., 2001; REICHART, 2001).

Descrições epidemiológicas de outras regiões do paí s, principalmente Norte e Nordeste, são, possivelmente, sub-registradas, caracterizando estas regiões como menos prevalentes para esta neoplasia e pouco contributórias para a descrição mais detalhada desta patologia (INCA, 2004). Discute-se se fatores ambientais regionais relacionados com os hábitos do Sul e Sudeste do pá s contribuem para esta maior incidência ou, se por terem se tornado centros de referência para tratamento levou à migração de pacientes das outras regiões. Discute-se, ainda, se o sub-registro de casos pelos órgãos responsáveis nas regiões de mais difí cil acesso à saúde do 
Norte e Nordeste tornam "supostamente" elevado o número de registro de CEB da Região Sul e Sudeste (INCA, 2004).

A língua foi o sítio de ocorrência mais freqüente na amostra estudada, correspondendo à localização mais freqüentemente registrada no Serviço de Cirurgia de Cabeça e Pescoço do HC-FMUSP publicado em levantamento concluí do em 2001 (ARAúUO FILHO et al., 1998; DURAZZO et al., 2001). De fato, devido à anatomia da língua, os tumores que se desenvolvem nesta região apresentam comportamentos biológicos particularmente mais agressivos. Acredita-se que a abundante presença de vasos linfáticos na região de submucosa esteja associada com metástases para linfonodos regionais e pior prognóstico para os pacientes, mesmo em tumores considerados pequenos (YUEN et al., 2000).

Ao avaliar a amostra deste estudo através da classificação TNM e UICC, os resultados apontaram uma alta incidência (66\%) de tumores avançados. Este fato pode ser reflexo de uma poĺ tica educativa ainda deficiente para detecção precoce e controle de casos iniciais nos serviços de tratamento de câncer no paí s. O câncer bucal, além de alcançar uma posição importante no "ranking" de mortalidade por câncer (que é a segunda causa de morte por doença no pás - INCA, 2004), é, ainda, responsável por grande morbidade, provocando seqüelas definitivas na qualidade de vida do paciente (ALMEIDA et al., 2004a; ALMEIDA et al., 2004b).

O valor prognóstico da classificação TNM vem sendo discutido por não refletir o padrão de invasibilidade celular na lesão sólida tridimensional (YUEN e al., 2000). As lesões pequenas de língua podem se associar a um pior prognóstico do que os tumores maiores de lábio, mesmo que sejam consideradas de graus histológicos semelhantes, pois a localização da lesão lingual é mais desfavorável para o prognóstico do paciente. Pelo acima exposto, a busca de outros marcadores 
prognósticos além dos já consagrados (isto é, localização da lesão, tamanho do tumor, espessura tumoral e outros) justifica a realização de estudos como o presente.

Existe uma tendência de se tentar relacionar as caracteń sticas clínicas e histopatológicas com o prognóstico da lesão. Trabalhos que venham correlacionar dados clí nico - patológicos a achados moleculares de CEB têm sido valorizados com a finalidade de se estabelecer aplicações clínicas para os marcadores moleculares. Contudo, é sabida a dificuldade de se obter o perfil molecular de certas neoplasias e conseqüentemente, a dificuldade de se obter uma terapêutica eficaz (SABBAGA, 2000).

No presente trabalho procurou-se estabelecer correlação entre os achados moleculares com dados clí nico-patológicos dos pacientes portadores de CEB. Com relação aos resultados obtidos através da técnica de RT-PCR, a amplificação do transcrito do gene HOXB13 pôde ser verificada tanto nas amostras de NT quanto de TT. A análise estaf́ stica empregada mostrou existir uma correlação positiva entre a presença dos transcritos do HOXB13 no tumor com a espessura tumoral, invasão perineural e a invasão vascular.

Entretanto, a amplificação dos transcritos nos tecidos dos grupos TT e NT foi comparável do ponto de vista estatí stico, e as amostras de TT não demonstraram relação com o tamanho do tumor, a localização da lesão, os graus histológicos ou o estágio pN apesar do respaldo da literatura que afirma serem estes fatores prognósticos determinantes para resposta à terapêutica do paciente portador de CEB ou outras neoplasias (FITZGIBBONS et al., 1999; MA et al., 2004; YUEN et al., 2000). 
Como relatado no capí tulo de Material e Métodos, o tecido não tumoral coletado correspondeu a fragmentos adjacentes ao tumor e que apesar da ausência macro e microscópica de neoplasia, alterações ultraestruturais (CHENG; HUDSON, 2002) e moleculares podem estar presentes (LOEB; LOEB 2000). Assim, a ausência de relação estatí stica entre a amplificação dos grupos TT e NT (por RT-PCR) não descarta a presença de alterações genéticas e/ou histopatológicas (atipias epiteliais, acantoses, disqueratoses e presença de infiltrado inflamatório) presentes na amostra NT. Desta forma, a correlação entre a amplificação do transcrito no TT com fatores prognósticos clí nicos (invasão perineural, invasão vascular e espessura) não pode ser invalidada. Mais que isso, tal correlação constitui num importante resultado positivo do presente trabalho dada a marcante importância destes fatores prognósticos na evolução dos doentes.

Vários autores como, por exemplo, Liu et al. (2004) suportam o consenso de que o CEB surge de um acúmulo de alterações genéticas, seqüenciadas ou não, que leva a ativação de oncogenes e perda de função de genes supressores de tumor. Suas conclusões se basearam em estudo onde um "screening" imunoistoquí mico foi realizado em 55 pacientes usuários de Areca que exibiram alterações de expressão das proteí nas p53, p21, Rb, ciclina D, MDM2 e Y-catenina numa porcentagem de $81,60,70,31,88$ e 44\% respectivamente. Seus resultados indicaram que a expressão da ciclina D e do MDM2 (gene humano homólogo ao gene "doble minute-2" em camundongos) são possivelmente capazes de inativar o p53 e a y-catenina, e que talvez sirvam como potenciais marcadores prognósticos já que exibiram relação com o tempo de sobrevida dos pacientes.

É importante salientar que as cascatas de alterações moleculares são complexas e muitas vezes interligadas, não favorecendo o estabelecimento concreto 
de vias relacionadas com o comportamento biológico de um determinado tumor, assim como foram estabelecidas várias vias para o estabelecimento do carcinoma de cólon. Assim, com as considerações acima, pretendeu-se apontar para a existência desta complexa rede de alterações genéticas, relacionadas ou não com os genes homeobox na carcinogênese bucal.

Os resultados obtidos mostraram que a maioria dos casos de TT e NT amplificou os transcritos do gene HOXB13 pela técnica de RT-PCR. Da mesma forma, foi possível observar a presença e a localização destes transcritos pela técnica de ISH dos fragmentos avaliados. E, apesar da expressão do gene HOXB13 ainda não ter sido estudada em CEB, o gene é apontado, assim como outros HOX, como importante candidato na diferenciação de queratinócitos e na formação e regeneração da pele tanto de camundongos quanto em humanos. De fato, Kömuves et al. (2003), utilizando a técnica de RT-PCR verificaram a amplificação do gene HOXB13 em queratinócitos cultivados. Os autores verificaram que o sinal do gene decresce à medida que estas células vão sofrendo diferenciação e entrando em apoptose. Assim, pode-se especular que se a diferenciação está relacionada com a diminuição da expressão, a desvios no processo de diferenciação poderiam estar relacionados com o retorno ou aumento da expressão do HOXB13 nos queratinócitos neoplásicos.

A presença do mRNA de genes Homeobox em tecidos adultos humanos já foi relatada, como por exemplo: o HOXB3 e o HOXB4 regulando a hematopoiese normal (LAWRENCE et al., 1996), e o PKNOX1 (Homeobox não agrupado) amplificado em tecidos cerebrais, coração, placenta, pulmão, fí gado, músculo, rins e pâncreas (CHEN et al., 1997). Em adição, resultados anteriores obtidos por Tucci (2000) no Laboratório de Biologia Molecular onde foi realizado o presente estudo, 
revelaram a expressão de genes $\mathrm{HOXB}$ em quatro linhagens de carcinoma epidermóide de boca. Os autores utilizaram a técnica de RT-PCR usando primers degenerados para a família $\mathrm{B}$, e assim, contribuindo com o estabelecimento da presente linha de pesquisa.

A similaridade seqüencial de pares de bases e da ação moduladora dos genes HOX fornece algum suporte para os resultados aqui apresentados. Outros Homeobox já foram identificados na pele normal e em tumores epiteliais. Rieger et al. (1994) identificaram o HOXC4 em pele de adulto pelas técnicas de RT-PCR e ISH. O HOXC4 foi localizado nas camadas suprabasais da epiderme da pele normal. Entretanto, nos queratinócitos neoplásicos do carcinoma basoceluar e da queratose solar, o transcrito estava ausente. Com respeito aos CEC de pele analisados, áreas bem diferenciadas com queratinização exibiram expressão do transcrito do HOXC4 e áreas pobremente diferenciadas foram negativas.

Apesar do resultado atual se tratar de outro gene HOX, nos achados deste trabalho, como pôde ser verificado no capí tulo de Resultados, o sinal dos transcritos decresce nas neoplasias moderamente e pouco diferenciadas quando comparadas com os CEB bem diferenciados (observar legendas das figuras).

Redline et al. (1994) encontraram que em alguns tumores sólidos o perfil de expressão dos genes Homeobox geralmente seguem o padrão do HOX normalmente encontrado no tecido normal que deu origem à lesão, sugerindo serem os HOX marcadores moleculares úteis para o diagnóstico de tumores de origem desconhecida. Este fato corrobora as sugestões de Cillo et al. (2001) ao afirmarem que já que os Homeobox têm função na correta estruturação e posicionamento dos órgãos ao longo eixo do corpo do embrião, então a expressão dos HOX é órgãoespeá fica. 
Ademais, Kömuves et al. (2003) avaliaram imunoistoquimicamente o padrão de expressão da proteína Hoxb13 em pele fetal e adulta de humanos e camundongos. Seus resultados mostraram que a proteí na Hoxb13 possui uma expressão citoplasmática na pele de humanos e camundongos, estando localizada nas células dos estratos espinhoso e granuloso da epiderme. Este padrão permaneceu o mesmo em condições proliferativas da pele como no carcinoma basocelular, no carcinoma epidermóide, queratoacantoma e queratoma sebáceo. Entretanto, nos casos de Sarcoma de Kaposi estudados, a proteí na inverte sua expressão marcando fortemente o núcleo das células neoplásicas.

Os cortes submetidos à técnica de ISH do presente trabalho também exibiram células positivas em todas as camadas do epitélio normal, assim como nas ilhotas neopásicas de CEB. Entretanto, devido às diferenças existentes entre as técnicas de imunoistoquí mica (aplicadas pelos autores KÖMUVES et al., 2003) e de ISH (utilizada neste trabalho) não foi possí vel avaliar a localização precisa do transcrito (nuclear ou citoplasmática) no grupo de células positivas. Este fato indica que, na continuidade da linha de pesquisa do Laboratório de Biologia Molecular da Disciplina de Patologia Bucal da Faculdade de Odontologia da USP, outras técnicas serão empregadas a fim de complementar os resultados atuais e fornecer algumas respostas adicionais às perguntas aqui levantadas.

O trabalho mais recente publicado na literatura envolvendo o HOXB13 foi o de Ma et al. (2004). Os autores avaliaram a expressão do gene com relação ao comportamento biológico em tumores de mama e revelaram que as células epiteliais de mama submetidas a superexpressão dos genes HOXB13 e IL17BR apresentam alterações morfológicas que aumentavam sua capacidade de mobilidade e migração celular favorecendo a recorrência e progressão da doença. 
Este grande achado do trabalho de Ma et al. (2004), entretanto, pouco contribui para o entendimento do comportamento biológico do CEB, pois, apesar dos tecidos terem origem embriológica semelhante (ectoderma), exibem etiopatogenias diferentes com comportamentos biológicos distintos. Contudo, o fato do gene HOXB13 ter se expressado nas glândulas salivares acessórias dos cortes de tecido não tumoral deste trabalho, não descarta a possibilidade de participação deste gene em outros tipos de neoplasias bucais (como, por exemplo, os tumores originados de glândulas salivares).

Edelman e Jones (1993) afirmaram que algumas moléculas de adesão celular podem ser reguladas por genes HOX, principalmente a N-CAN (molécula de adesão neural). Ford (1998) afirmou que os genes alvo dos Homeobox ainda não são bem estabelecidos, mas é provável que regulem genes da matriz extracelular, moléculas de adesão e fatores de crescimento, os quais são importantes na morfogênese e, assim, no fenômeno de metástase.

Não obstante, publicações também recentes trazem resultados conflitantes com a possibilidade da expressão do HOXB13 limitar a capacidade proliferativa celular por possuir uma capacidade apoptótica em tecidos normais de camundongos. Economides, Zeltser e Capecchi (2003) verificaram que camundongos com perda de função do Hoxb13 (nocaute Hoxb13 ${ }^{-/}$) nasciam com caudas maiores que os camundongos normais, sugerindo assim que este gene age como inibidor da proliferação celular ativando as vias apoptóticas das vértebras e tubo neural, estruturas igualmente de origem ectodérmica como o epitélio da superfí cie bucal.

Sabe-se que os genes HOX podem ser modulados em ní vel transcripcional ou pós-transcripcional (MARTINEZ; AMEMIYA, 2002). Os genes da famí lia do BMP, 
TGF- $\beta$ FGF, Hedgehog e WNT têm papel importante na morfogênese do embrião, regulando os genes Homeobox. Estes últimos, quando mutados, seriam supostamente capazes de provocar alterações estruturais tridimensionais nos tecidos e órgãos por uma alteração primária nas moléculas de adesão (CILLO et al., 2001). Fatores de transcrição, incluindo as homeoprotén nas, reguladoras de atividades importantes relacionadas ao crescimento, proliferação e diferencição celular, assim como a comunicação entre as células e também a apoptose conseqüentemente se alterariam (CHARIOT et al., 1998),

Pode-se perceber que os mecanismos que envolvem o gene HOXB13 são muito complexos e pouco esclarecidos. É possí vel que esteja envolvido de forma diferente na diferenciação da célula "normal" e da célula "neoplásica" já que está envolvido na cascata de vários genes importantes. Desta forma, como afirma Cillo et al. (1999) seu papel no processo de transformação maligna também não pode ser descartado.

Mack et al. (2003), através da imunoistoquímica, localizaram a proteí na do gene Hoxb13 tanto no núcleo quanto no citoplasma da epiderme, nas células do folí culo piloso e nos fibroblastos da derme de camundongos adultos. Sua expressão mostrou-se aumentada no processo de cicatrização de feridas dando suporte a sua função regulatória sobre a derme e a epiderme. Os camundongos nocaute

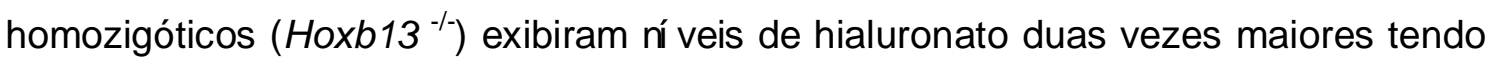
sua cicatrização mais rápida do que em ratos normais e com uma deposição de fibras colágenas mais organizadas.

Com relação à expressão do HOXB13 em tecidos adultos normais os resultados de Mack et al. (2003) apontam prováveis soluções para problemas estéticos do processo da cicatrização. Mas, como transferir e interpretar seus 
resultados no câncer de boca se, através da técnica utilizada, foi verificado um padrão invariável de expressão para os tecidos estudados? Mesmo os cortes que se mostraram negativos através da ISH podem ser explicados pela sensibilidade e facilidade de degradação da molécula de RNA, não os excluindo definitivamente da possibilidade de já ter possuí do o transcrito.

Diante do exposto acima, para a amostra estuda, pode-se sugerir que, no tumor, a permanência de células positivas (queratinócitos neoplásicos) para os transcritos do HOXB13 favorece um aumento na taxa de crescimento tumoral ao inibir uma resposta do hospedeiro.

Ou ainda, o fato dos Homeobox terem estruturas moleculares semelhantes e serem apontados como reguladores de molécula de adesão e matriz intercelular, sua desregulação, principalmente no que se refere ao HOXB13, poderia facilitar a invasibilidade e mobilidade celular para dentro de estruturas adjacentes. Conforme foi demonstrado no trabalho de câncer de mama de Ma et al. (2004), no qual o aumento da expressão do gene HOXB13 prediz a recorrência e progressão da doença.

Enfim, no presente trabalho, existe uma relação estatí stica entre a amplificação do transcrito do gene HOXB13 e alguns fatores prognósticos importantes. Entretanto, cálculos matemáticos de um estudo isolado não permitem incluir ou descartar estes genes como marcadores prognósticos moleculares, sendo estes apenas os primeiros passos para a compreensão do papel do HOXB13 no estabelecimento de uma terapia gênica futura. Como discutido anteriormente, outras técnicas laboratoriais para análise da expressão do gene HOXB13 e o aumento da amostra de CEBs em trabalhos futuros deverão ser levados em consideração. 
Para discussão dos achados do gene HHEX a literatura também é escassa, e a inexistência de artigos envolvendo células neoplásicas, e, principalmente de células neoplásicas de tumores sólidos humanos, dificulta grandemente o estudo e a discussão do envolvimento do gene Hhex na carcinogênese oral e a obtenção de conclusões.

Através da técnica de ISH, observou-se que os cortes de NT exibe uma expressão do HHEX dispersa e tênue por quase todos diferentes tecidos presentes nos fragmentos. A marcação foi considerada especí fica por estar levemente mais concentrada em algumas estruturas (por exemplo: endotélio) e pelo fato da sonda senso usada como controle negativo não exibir nenhuma marcação. De fato, a literatura revela que o nocaute $H_{h e x}{ }^{-/}$é letal para os embriões (BOGUE et al., 2003), justificando esta expressão em ní veis "basais" ou quiescentes, aguardando algum comando ou motivo para retornar a se expressar com intensidade. Além disso, o gene HHEX, durante o desenvolvimento embrionário, é apontado como responsável pelo desenvolvimento de hemangioblastos, órgãos relacionados com a hematopoiese (RODRIGUES et al., 2001; SEKIGUCHI et al., 2001; THOMAS; BROWN; BEDDINGTON, 1998) e na diferenciação de células do sistema imunológico (BEDFORD et al., 1993), todos essenciais para a vida.

Há uma tentativa atual de explicar sua regulação durante a embriogênese facilitada principalmente pelo seu modelo de estudo preferencial: o peixe-zebra, o qual oferece inúmeras vantagens (PATTON; ZON, 2001) e terminou por estabelecer bem sua função na embriogênese (LIAO et al., 2000; RODRIGUES et al., 2001; THOMAS; BROWN; BEDDINGTON, 1998). Conseqüentemente, sua desregulação desempenha justificado papel nas neoplasias de origem hematopoiética como os 
linfomas (MANFIOLETTI et al., 1995; WANG et al., 1999) e leucemias (BEDFORD et al., 1993).

Sua expressão em queratinócitos, no entanto, não foi estabelecida. E apesar de ter forte influencia na morfogênese e diferenciação celular de estruturas oriundas do mesoderma (ZHANG et al., 2002) e endoderma (KENG et al., 2000; TANAKA et al., 1999), nos resultados do presente estudo a presença do transcrito foi verificada em estruturas de origem no ectoderma como, por exemplo, na pele, glândulas salivares acessórias e seus ductos.

Nos fragmentos de tecido não tumoral ainda é possível verificar uma intensidade de expressão levemente mais forte no conjuntivo da lâmina própria quando comparado com o epitélio de superfí cie. Entretanto, nos cortes de neoplasia este padrão inverte, passando a ser significantemente mais evidente nas ilhotas neoplásicas. A ausência de literatura espeć fica não nos permite maiores considerações; no entanto, a neoformação vascular e angiogênese das neoplasias malignas ou benignas poderiam estar facilitadas ou influenciadas por fatores de crescimentos. È possí vel que estes fatores sejam capazes de modular, ou de estarem modulados, pelo HHEX favorecendo maior suprimento sanguí neo para a neoplasia.

Nos resultados obtidos através da técnica de RT-PCR há uma relação estatí stica significante entre a amplificação do transcrito do HHEX e a presença de invasão vascular no tumor. Mas como explicar esta relação? É possí vel que a neoplasia, induzida por fatores de crescimento tumoral, e ainda apresentando fatores de necrose tumoral, emitam fatores quimiotáticos que excitem a expressão do HHEX e recrutem sua proté na para esta região. 
Outra possibilidade que não pode ser excluí da é a de que uma maior mobilidade celular, estabelecida por uma cascata de alterações paralelas da carcinogênese, que envolva o gene HHEX favoreça a invasão das células através dos vasos; ou, o mais provável: um aumento do número de vasos disponí veis (induzidos pelo HHEX) para serem invadidos por tais células com alterações genéticas distinta da cascata do HHEX, como foi sugerido nos resultados de Sekiguchi et al. (2001), o qual sugere um papel indutor na formação de vasos pelo HHEX quando estimulado.

Retornando aos resultados obtidos através da técnica de ISH, verificamos que células inflamatórias presentes nos dois grupos de tecido expressaram a presença dos transcritos do HHEX. Esta expressão pode ser justificada com dados já relatados sobre o papel do HHEX na diferenciação de células linfáticas e conseqüentemente anticorpos (BOGUE et al., 2003; GUO et al., 2003). Poderia-se conjecturar alguma tentativa do sistema imunológico de bloquear a progressão neoplásica com o "retorno" ou aumento da expressão do gene, pois, segundo Anneroth, Batsakis e Luna (1987), a presença de infiltrado inflamatório no carcinoma epidermóide corresponderia a uma reação positiva do hospedeiro contra a progressão da lesão. Para a amostra estudada, e possí vel que o HHEX esteja ativado nas células linfáticas que estariam reagindo à progressão da lesão através do estímulo do aumento do número de células inflamatórias na neoplasia e adjacente à lesão.

Em oposição, os resultados de Sobral et al. (2004) revelaram que a presença do infiltrado inflamatório no estroma de carcinoma mucoepidermóide impedia a diferenciação dos fibroblastos em miofibroblastos significando um pior prognóstico para o paciente por facilitar a progressão da neoplasia. Entretanto, uma colocação 
importante no trabalho dos autores que pode ser transposto para o trabalho atual é sobre a relevância de estudos que analisam a influência dos componentes do estroma sobre as células neoplásicas. E, neste ponto, pode-se considerar o trabalho em conjunto de genes Homeobox atuando tanto nos componentes neoplásicos quanto nos componentes estromais. Revelam-se as atuações "interligadas" dos Homeobox e assim justifica-se o fato de a maior parte dos trabalhos publicados considerarem sempre a análise de mais de um gene. Assim, no presente trabalho, o gene HOXB13 parece estar mais expresso em populações celulares com origem no ectoderma e o HHEX em populações celulares com origem no mesoderma e endoderma. Apesar disso, nenhuma relação entre a expressão destes genes foi estabelecida na literatura.

Com referência a relação inversa da amplificação do transcrito, pela técnica de RT-PCR, do gene HHEX com a idade do paciente, não se tem explicação para o momento. Uma possibilidade estaria nos jovens possú rem maior capacidade angiogênica, ou de resposta imunológica, que os pacientes de idades mais avançadas.

Destarte, uma vez mais, a ausência de dados especí ficos do papel do HHEX no carcinoma epidermóide, assim como a ausência de dados sobre o funcionamento de sua protế na, desfavorece conclusões mais categóricas. Mas, sua relação estatística positiva com fatores prognósticos clínicos e patológicos bem estabelecidos sugere que este possa ser um possí vel marcador biológico para avaliar o comportamento do carcinoma epidermóide de boca. Diga-se, a correlação da amplificação dos transcritos deste gene com a invasão vascular, do ponto de vista estatí stico, ser bastante forte. 
A literatura internacional eventualmente afirma que existe um possí vel papel dos Homeobox no processo da carcinogênese, mas dados mais concretos, amostras maiores e associações com técnicas (por exemplo: um "microarray" para obter o perfil dos Homeobox no câncer de boca) mais complexas interagindo genoma $\mathrm{X}$ proteoma são necessários para o estabelecimento do papel dos genes Homeobox como oncogenes, supressores de tumor ou mesmo apenas moduladores.

A técnica de ISH surgiu revolucionando o entendimento da estrutura, função, organização e evolução dos genes e genomas. A ISH de moléculas de mRNA, em particular, permite localizar o transcrito do gene dentro de um contexto morfológico, esclarecendo o padrão de expressão de um gene específico e a abundância do transcrito no tecido estudado, sendo a melhor técnica para avaliar a presença de transcritos em espécimes (SCHWARZACHER; HESLOP-HARRISON, 2000). Por estas, entre outras razões, foi umas das técnicas escolhidas para realização deste estudo, com a finalidade de esclarecer quais populações celulares apresentavam os transcritos dos genes HOXB13 e HHEX no carcinoma epidermóide de boca.

Atualmente a técnica de ISH tem sido rotineiramente e principalmente utilizada em estudos sobre os aspectos cŕ ticos do desenvolvimento biológico de várias espécies animais (GOODMAN et al., 2002; MELTON, 1991; ROBERTIS et al., 1990), e a expressão de patógenos virais ou bacterianos "intrusos" na seqüência de genes eucariotas também podem ser observada (BARBOSA-SOLOMIEU, 2004; QIAN et al., 2004).

Finalmente, a técnica de ISH apresenta a população de célula que expressa determinado transcrito, entretanto ainda restam dúvidas se sua tradução é concluí da, ou se proteí nas truncadas com perda de função são formadas. Mas, para o objetivo deste trabalho, a técnica selecionada teve importância fundamental, 
tornando possí vel sugerir que ambos genes estudados possuem relação com importantes fatores prognósticos. É provável que amostras maiores forneçam respostas mais concretas.

O trabalho deverá ser continuado na linha de pesquisa do Laboratório de Biologia Molecular da FOUSP, pois várias perguntas ainda podem ser feitas ou respondidas. E, enfim, podemos afirmar que os resultados apresentados neste estudo contribuí ram para confecção de mais uma peça no enorme "quebra-cabeça" da carcinogênese bucal. 


\section{CONCLUSÕES}

7.1 A amplificação dos transcritos dos genes HOXB13 e HHEX podem ser verificadas tanto no carcinoma epidermóide quanto no tecido não tumoral adjacente à lesão;

7.2 A amplificação do transcrito do gene HOXB13 mostrou relação estat́ stica com os seguintes fatores prognósticos: espessura tumoral, invasão perineural e invasão vascular;

7.3 A amplificação do transcrito do gene HHEX mostrou relação estat́ stica com os seguintes fatores prognósticos: invasão vascular, envolvimento com os tecidos adjacentes e uma relação inversa com a idade do paciente;

7.4 A expressão dos transcritos do gene HOXB13, detectados pela técnica de ISH, mostrou um padrão de marcação consistente e invariável para os tecidos não tumorais analisados exibindo marcação principalmente o epitélio de superfí cie e células endoteliais. Enquanto que nas amostras de carcinoma epidermóide esta expressão apresentou-se mais intensa nas ilhotas neoplásicas decrescendo com o grau de diferenciação histológica do tumor; 
7.5 A expressão dos transcritos do gene HHEX, detectados pela técnica de ISH, mostrou um padrão de marcação consistente e tênue para os tecidos não tumorais analisados exibindo, geralmente, o epitélio de superfí cie negativo e o conjuntivo e vasos sangǘ neos positivos. Enquanto que nas amostras de carcinoma epidermóide esta expressão apresentou-se inversa, estando mais intensa nas ilhotas neoplásicas em relação ao estroma e decrescendo com o grau de diferenciação histológica do tumor. 


\section{REFERÊ NCIAS ${ }^{1}$}

Abate-Shen C. Deregulated homeobox gene expression in cancer: cause or consequence? Nat Reviews 2002;2:777-85.

Acampora D, Désposito M, Faiella A, Pannese M, Migliaccio E, Morelli F, et al. The human Hox gene family. Nucleic Acids Research 1989;17(24):10385-401.

AJCC cancer staging handbook: for the ajcc cancer staging manual. $5^{\text {th }}$ ed. Philadelphia: Lippincott Williams \& Wilkins; 1998. 267 p.

Almeida FCS, Cazal C, Durazzo MD, Ferraz AR, Silva DP. Radioterapia em cabeça e pescoço: efeitos colaterais agudos e crônicos bucais. Rev Bras de Patol Oral 2004a;3(2):62-9.

Almeida FCS, Vaccarezza GF, Cazal C, Benedethe APF, Pinto Jr D, Tavares MR, et al. Avaliação odontológica de pacientes com câncer de boca pré e pós tratamento oncológico: uma proposta de protocolo. Pesq Bras Odontoped Clin Integr 2004b;4(1):27-33.

Anneroth G, Batsakis J, Luna M. Review of the literature and a recommended supplement of malignancy gadring in oral squamous cell carcinoma. Scand Dent Res 1987;95(3):229-49.

Araújo Filho VJ, Carlucci Junior D, Sasaki SU, Montag E, Azato Cordeiro AC, Ferraz AR. Incidence of oral cancer profile at a general hospital in São Paulo. Rev Hosp Clin Fac Med São Paulo 1998;53(3):110-3.

Barbosa-Solomieu V, Miossec L, Vazquez-Juarez R, Ascencio- Valle F, Renaut T. Diagnosis of ostreid herpesvirus 1 in fixed paraffin-embedded archival samples using PCR and in situ hybridization. J Virol Methods 2004;119(2):65-72.

Bedford FK, Ashworth A, Enver T, Wiedemann LM. Hex: a novel homeobox gene expressed during haematopoiesis and conserved between mouse and human. Nucleic Acids Research 1993;21(5):1245-9.

\footnotetext{
${ }^{1}$ De acordo com Estilo Vancouver. Abreviatura de periódicos segundo base de dados MEDLINE.
} 
Bijl JJ, van Oostveen JW, Walboomers JMM, Horstman A, van den Brule AJC, Willemze R, et al. HOXC4, HOXC5 and HOXC6 expression in non-hodgkin's lynphoma: Preferencial expression of HOXC5 gene in primary cutaneous anaplastic T-cell and oro-gastrointestinal tract mucosa-associated B-cell lynphomas. Blood 1997;90(10):4116-25.

Bogue CW, Zhang PX, McGrath J, Jacobs HC, Fuleihan RL. Impared B cell development and function in mice with a targed disruption of the homeobox gene Hex. PNAS 2003;100(2):556-61.

Braakhuis BJM, Leemans CR, Brakenhoff RH. A genetic progression model of oral cancer: current evidence and clinical implications. J Oral Pathol Med 2004;33:317-22.

Brickman JM, Jones CM, Clements M, Smith JC, Beddington RS. Hex is a transcriptional repressor that contributes to anterior identity and suppresses Spermann organizer function. Development 2000;127:2303-15.

Bridge CB, Morgan TH. The third chromosome group of mutant characters of Drosophila melanogaster. Carnegie Inst Wash 1923;327:93.

Carlson MRJ, Komine Y, Bryant SV, Garddiner. Expression of hoxb13 and hoxc10 in developing and regenerating Axolot/ limbs and tails. Dev Biol 2001;229:396-406.

Chang PY, Kozono T, Chida K, Kuroki T, Huh N. Differential expression of hox genes in multistage carcinogenesis of mouse skin. Biochem Bioph Res Commun 1998;248:749-52.

Chariot C, Seuterre-Lessenfant S, Sobel ME, Castronovv V. Molecular cloning of a mutated Hoxb7 cDNA encoding a truncated transactivating homeodomain-contain protein. J Cell Biochem 1998;71(1):46-54.

Chen H, Rossier C, Nakamura Y, Lynn A, Chakravarti A, Antonarakis SE. Cloning of a novel homeobox-containing gene, PKNOX1, and mapping to human Chromosome 21q22.3. Genomics 1997;41:193-200.

Cheng LHH, Hudson J. Ultrastrutural changes in malignant transformation of oral mucosa. Brit J Oral Maxilofac Surg 2002;40:207-12.

Choi K, Kennedy M, Karazov A, Papadimitriou JC, Keller G. A common precursos for hematopoietic and endothelial cells. Development 1998;125:725-32.

Cillo C, Cantile M, Faiella A, Boncinelli E. Homeobox genes in normal and malignant cell. J Cell Physiol 2001;188:161-9.

Cillo C, Fanolla A, Cantile M, Boncinelli E. Homeobox genes and Cancer. Exp Cell Res 1999;248:1-9.

Cillo C. Hox Genes in human cancers. Invasion Metastasis 1994-95;14:38-49. 
Crompton MR, Bartlett TJ, MacGregor AD, Mafioletti G, Buratti E, ,Giancotti V, et al. Identification of a novel vertebrate homeobox gene expressed in hematopoietic cell. Nucleic Acids Res 1992;20:5661-7.

Crowhurst MO, Layton LE, Lieschke GL. Developmental biology of zerafish myeloid cells. Int J Dev Biol 2002;46:483-92.

Denson LA, Karpen SJ, Bogue CW, Jacobs HC. Divergent homeobox gene hex regulates promoter of the $\mathrm{Na}+$-dependent bile acid cotransporter. Am J Physiol Gastrointest Liver Physiol 2000;279:G347-G355.

Dib LL,Pinto BS, Sanvitto LC, Contezini H, Lombardo V, Franco E. Determinantes da sobrevida em câncer de boca: fatores sócio-demográficos e anatômicos. Rev Bras Cir Cabeça Pescoço 1990;14:1-9.

Durazzo MD, Silva Filho GB. Tratamento do câncer da cavidade oral. Rev Med 1997;76(5):256-9.

Durazzo MD, Tavares MR, Araújo CEN, Neto JSB, Matsunaga P, Potenza AS, etal. Perfil dos portadores de câncer da cavidade oral operados de 1994 a 1998: predomí nio de doença local avançada e aumento da incidência de mulheres. Rev Bras Cir Cabeça Pescoço 2001;25(1):7-10.

Economides KD, Capecchi MR. Hoxb13 is required for normal differentiation and secretory function of the ventral prostate. Development 2003;130:2061-9.

Economides KD, Zeltser L, Capecchi MR. HOXB13 mutation cause overgrowth of caudal spinal cord and tail vertebrae. Dev Biol 2003;256:317-30.

Edelman GM, Jones FS. Outside and downstream of the homeobox. J Biol Chem 1993;268(28):20683-6.

Fisher D, Méchali M. Vertebrate Hoxb gene expression requires DNA replication. EMBO J 2003;22(14):3737-48.

Fitzgibbons PL, Page DL, Weave D, Thor AD, Allred DC, Clarck GM, et al. Prognostic factors in breast câncer. College of American Pathology sensus Statement. Arch Pathol Lab Med 1999;124:966-78.

Ford HL. Homeobox genes: A link between development, cell cycle, and cancer? Cell Biol Int 1998;22(6):397-400.

Franco EL, Kowalski LP, Oliveira BV, Curado MP, Pereira RN, Silva ME, etal. Risk factors for oral cancer in Brazil: a case-control study. Int J Cancer 1989;43(6):9921000.

Gehring WJ. Homeoboxes in the study of development. Science 1987;236:1245-52.

Ghosh B, Ganea GR, Denson LA, ,lannucci R, Jacobs H, Bogue CW. Immunocytochemical characterization of murine Hex, a homeobox-conteining protein. Pediatr Res 2000;48(5):634-8. 
Gonzalez-Moles MA, Esteban F, Rodriguez-Archilla A, Ruiz-Avila I, Gonzalez-Mole S. Importance of tumour thickness mesurement in prognosis of tongue cancer. Oral Oncol 2002;38:394-7.

Goodman FR, Bacchelli C, Brady AF, Braeton LA, Fryns JP, Mortlock DP, et al. Novel HOXA13 utations and the phenotypic spectrum of hand-foot-genital syndrome. Am J Hum Genet 2000;67:197-202.

Guo Y, Chan R, Ramsey H, Li W, Xie X, Shelley WC, et al. The homeoprotein hex is required for hemangioblast differentiation. Blood 2003;102(7):2428-35.

Hamer BD, Higgins SJ. Nucleic acid hybridization. A practical approach. $2^{\text {nd }}$ ed. Oxford: IRL Press Limited; 1985.

Instituto Nacional do Câncer (INCA). Estimativa da incidência e mortalidade por câncer no brasil. Disponí vel em URL:

http://www.inca.org.br/epidemiologia/estimativa2003/estimativas.html [2004 05 09].

Jave-Suarez LF, Winter H, Langbein L, Rogers MA. Hoxc13 is involve in the regulation of human hair keratin. J Biol Chemistry 2002;277(1):3718-26.

Keng VW, Yagi H, Ikawa M, Naganos T, Myint Z, Yamada K, et al. Homeobox gene hex is essential for onset of mouse embryonic liver development and diferentiation of monocyte linege. Biochem Biophys Res Commun 2000;278:1155-61.

Kjaer KW, Hedeboe J, Bugge M, Hansen C, Friis-Henriksen K, Vestergaard MB, et al. HOXD13 polyalanine tract expansion in classical synpolydactyly type vordingborg. Am J Med Genet 2002;110:116-21.

Kömüves LG, Ma X-K, Steinicki E, Rozenfeld S, Oda Y, Largman C. HOXB13 homeodomain protein is cytoplasmic throughout fetal skin development. Dev Dyn 2003;227:192-202.

Kokemueller H, Brachvogel P, Eckardt A, Hausamen JE. Neck Dissection in oral cancer - clinical review and analysis of prognostic factors. Oral Maxillofac Sur 2002; 31:608-14.

Kramer D, Durham JS, Jackson S, Brookes J. Management of the neck in N0 squamous cell carcinoma of the oral cavity. J Otolaryngol 2001;30(5):283-8.

Lawrence HJ, Sauvageau G, Humphries KR, Largman C. The role of HOX homeobox genes in normal and leukemic hematopoiesis. Stem Cells 1996;14:281-91.

Lewis, EB. A gene complex controlling segmentation in Drosophila. Nature 1978;276(5688):565-70. 
Liao W, Ho CY, Yn YL, Postlethwait J, Stainier DYR. Hhex and Scl function in parallel to regulate early endothelial and blood differenctiation in zebrafish. Development 2000;127:4303-13.

Liao EC, Paw BH, Oates AC, Pratt SJ, Postlethwait JH, Zon LI. SCL/Tal-1 transcription factot acts downstream of choche to specify hematopoietic and vascular progenitors in zebrafish. Genes Dev 1998;12:621-6.

Liu CJ, Chang KW, Chao SY, Kwan PC, Chang SM, Yen RY, et al. The molecular markers for prognostic evaluation of areca-associated buccal squamous cell carcinoma. J Oral Pathol Med 2004;33:327-34.

Loeb KR, Loeb LA. Significance of multiple mutation in cancer. Carcinogenesis 2000;21(3):379-85.

Loeb LA. A mutator phenotype in Cancer. Cancer Res 2001;61:3230-9.

Louro ID. Proto-oncogene e gene superessores de tumor. In: Louro ID, Herena Júnior JC, Melo MSV, Ashton-Prolla P, Contorti-Froes N. Genética Molecular do Câncer. São Paulo: MSG; 2002. cap. 6, pt. 2A, p. 63-79.

Ma XJ, Wang Z, Ryan PD, Isakoff SJ, Barmettler A, Fuller A, et al. A two-gene expression ratio predicts clinical outcome in breast cancer patients treated with tamoxifen. Cancer Cell 2004;5:607-16.

Mack JA, Abramson SR, Ben Y, Coffin JC, Rothrock JK, Maytin EV, et al. Hoxb13 knockout adult skin exhibits hig levels of hyaluronan and enhanced wound healing. FASEB J 2003;17:1352-4.

Manfioletti G, Gatti V, Buratti E, Rustighi A, De Lullis A, Aldinucci D, et al. Differential expression of a novel proline-rich homeobox gene (Prh) in human hematolynphopoietic cells. Blood 1995;85:1237-45.

Mark M, Rijli FM, Ckambon P. Homeobox genes in embryogenesis and pathogesis. Pediatr Res 1997;42(4):1-19.

Martinez-Barbera JP, Clements M,Thomas P, Rodriguez T, Meloy D, Kioussis D, et al. The homeobox gene Hex is required in definitive endodermal tissue for normal forebrain, liver and thyroid formation. Development 2000;127:2433-45.

Martinez P, Amemiya CT. Genomics of the Hox gene cluster. Comp Biochem Physiol B Biochem Mol Biol 2002;133:574-80.

Medina-Martí nez O, Bradley A, Ramí rez-Solis R. A large targeted deletion of hoxb1hoxb9 produce a series of single-segument anterior homeotic transformations. Dev Biol 2000;222:71-83.

Melton DA. Pattern formation during animal development. Science 1991;252:234-41. 
Mignogna MD, Fedele S, Ruoppo E, Russo LL. The role of molecular techniques in preventing oral cancer and improving its poor prognostisis: an illusion? J Oral Pathol Med 2002;31:246-8.

Mishra RC, Parida G, Mishra TK, Mohanty S. Tumour thickness and relationship to localregional failure in cancer of the buccal mucosa. Eur J Surg Oncol 1999;25:1869.

Neto ED. O projeto genoma humano e a contribuição do projeto genoma do câncer brasileiro. Biológico 2001;63(1/2):33-5.

Nunes FD, Almeida FCS, Tucci R, Sousa SCOM. Homeobox genes: a molecular link between development and cancer. Pesqui Odontol Bras 2003;17(1):94-8.

Pape HD. Proleferative activity and loss of function of tumor supressor genes as 'biomarkers' in diagnosis and prognosis of bening and preneoplastic oral lesions and oral squamous carcinoma. Br J Oral Maxillofac Surg 1998;36(4):252-60.

Patton EE, Zon LI. The art and design of genetic screens: zebrafish. Nature Rev $2001 ; 2: 956-66$.

Qian X, Guerrero RB, Plummer TB, Alves VF, Lloyd RV. Detection of hepatitis C ví rus RNA in formalin-fixed paraffin-embedded sections with digoxigenin-labeled cRNA probes. Diag Mol Pathol 2004;13(1):9-14.

Redline RW, Hudock P, MacFee M, Patterson P. Expression of AbdB-Type homeobox genes in human cancer. Labor Invest 1994;71(5):663-70.

Reichart PA. Identification of risk groups for oral precancer and cancer and preventive measures. Clin Oral Investig 2001;5(4):207-13.

Rieger E, Bijl JJ, van Oostveen JW, Soyer P, Oudejans CBM, Jiwa NM, et al. Expressio of the homeobos gene HOXC4 in keratinocytes of normal skin and epithelial skin tumors is correlated with differentiation. J Invest Dermatol 1994;103:341-5.

Risau W, Flamer I. Vasculogenesis. Ann Rev Cell Dev Biol 1995;11:73-91.

Robertis EM, Oliver G, Wright CVE. Homeobox Genes and the vertebrate body plan. Sci Am 1990;46-52.

Rodrigues TA, Casey ES, Herland RM, Smith JC, Beddington SP. Distinct Enhancer elements control hex expression during gastrulation and early organogenesis. Dev Biol 2001;234:304-16.

Sabbaga S. Oncogenes e antioncogenis. In: Parise Jr. O Câncer de boca: aspectos clí nicos e terapêuticos. São Paulo: Elsevier; 2000. cap. 4, p. 23-8.

Schwarzacher T, Heslop-Harrison P. Pratical in situ Hybridization. New York: BIOS Scientific Publishers; 2000. 203 p. 
Scott MP. Vertebrate homeobox gene nomenclature. Cell 1992;71:551-3.

Sekiguchi K, Masahiro K, Oyama Y, Aihara Y, Tanaka T, Sakamoro H, et al. Homeobox protein hex induces Smemb/nonmuscle Myosin heavy chain-B gene expression through the cAMP-responsive element. Circ Res 2001;88:52-8.

Sobral APV, Loducca SVL, Nunes FD, Araújo NS, Kowalski LP, Araújo VC. Relatonship between major and minor salivary gland mucoepidermoid carcinoma malignancy grading and presence of stromal myofibroblasts: immunohistochemical study. J Oral Pathol Med 2004;33:335-9.

Stain S, Fritsch R, Lemaire L, Kessel M. Checklist: vertebrate homeobox genes. Mech Dev 1996;55:91-108.

Sutton DN, Brown JS, Rogers SN, Vaughan ED, Woolgar JA. The prognostic implications of the surgical margin in oral squamous cell carcinoma. Oral Maxillofac Surg 2003;32:30-4.

Tabachnick BG, Fidell LS. Using multivariate statistics. $3^{a}$ ed. New York: Harper Collins College Publishers; 1996. 880 p.

Tanaka T, Inazu T, Yamada K, Myint Z, Keng VW, Inoue Y,et al. cDNA cloning and expression of rat homeobox gene, hhex, and functional characterization of the protein. Biochem J 1999;339:111-7.

Tavares MR, Noma RK. Epidemiologia e fatores de risco do câncer da cavidade oral. Rev Med 1997;76(5):256-9.

Thomas PQ, Brown A, Beddington RSP. Hex: a homeobox gene revealing periimplantation asymmetry in the mouse embrio and an early transient marker of endothelial cell prescursors. Development 1998;125:85-94.

Topisirovic I, Culjkovic B, Cohen N, Perez JM, Skabanek L, Borden KLB. The prolinerich homeodomain protein, $\mathrm{PRH}$, is a tissue-specific inhibitor of elF4E-dependent cyclin D1 mRNA transport and growth. EMBO J 2003;22(3):689-703.

Tucci R. Expressão do mRNA de genes Hox em linhagens celulares de carcinoma epidermóide bucais [Dissertação de Mestrado]. São Paulo: Faculdade de Odontologia da Universidade de São Paulo; 2000.

UICC (Union Internationale Contre le Cancer). Illustrated Guide for TNM /pTNM classification of malignant tumours. Heidelberg: Springer-Verlag; 1992. 359 p.

Wang S, Rosenwald IB, Hutzler MJ, Pihan GA, Savas L, Chen JJ, et al. Expression of the eucariótic translation initiation factor $4 \mathrm{E}$ and $2 \alpha$ in non-hodgkin's symphomas. Am J Pathol 1999;155(1):247-55.

Wu DK, Oh SH. Sensory organ generation in the chick inner ear. J Neurosc 1996;16(20):6454-62. 
Yuen APW, Lam KY, Wei WI, Lam KY, Ho CM, Chow TL, et al. A comparison of the prognostic significance of tumor diameter, length, width, thickness, area, volume and clinicopathological features of oral tongue carcinoma. Am J Surgery 2000;180:13943.

Zar ZH. Biostatistical analysis. 4를 ed. New Jersey: Prentice Hall; 1999. 663 p.

Zeltser L, Desplan C, Heintz N. Hox-B13: a new hox gene in a distant region of the HOXB cluster maintains colinearity. Development 1996;122:2475-84.

Zhang W, Yatskievych TA, Caos X, Antin PB. Regulation of hex gene expression by a smards-dependent signaling pathway. J Biol Chem 2002;277(47):45435-41. 
ANEXOS 


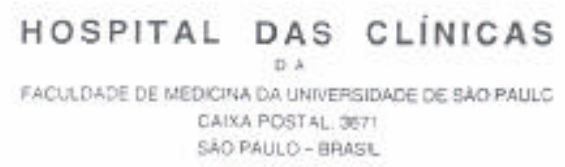

DIRETORIA CLÍNICA

\section{Comissão de Ética para Análise de Projetos de Pesquisa}

\section{APROVACÃO}

A Comissão de Ética para Análise de Projetos de Pesquisa - CAPPesq da Diretoria Clínica do Hospital das Clínicas e da Faculdade de Medicina da Universidade de São Paulo, em sessão de 12.12.01, APROVOU o Protocolo de Pesquisa $n^{\circ}$ 566/01, intitulado: "Estudo da expressäo de genes homeobox em carcinomas epidermóides de boca", apresentado pelo(a) pesquisador(a) DR. MARCOS ROBERTO TAVARES, do Departamento de CIRELRGIA. bem como o Termo de Consentimento Livre e Esclarecido.

CAPPesq, 12 de Dezembra de 2001.

PROF. DR. JORGE KALIL FILHO

Presidente da Comissäo Ética para Análise de Projetos de Pesquisa

OBSERVAÇÃO: Cabe ao pesquisador elaborar e apresentar à CAPPesq, os relatórios parciais e final sobre a pesquisa (Resoluçāo do Canselha Nacional de Saúde $n^{\circ} 196$, de 10.10.1996, inciso IX.2, letra "c) 
Disciplina de Patologia Bucal

Faculdade de Odontologia
Hospital das Cll nicas

Faculdade de Medicina
UNIVERSIDADE DE SÃO PAULO

TERMO DE CONS ENT I MENTO PÓS - I NFO RMA Ç ÃO

\section{I- Dados de identificaçã o do sujeito da pesquisa ou responsá vel legal}

1- Nome do paciente:

Documento de Identidade:
Data de Nascimento:
Endereço:
Bairro:
CEP:

2- Nome do responsável legal:

Grau de parentesco com o sujeito da pesquisa:

Documento de Identidade:

Data de Nascimento:

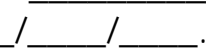

Endereço:

Bairro:

Cidade:

CEP: Telefone:

Sexo: ()$^{M}(\bar{F}$

N.

Apto.

\section{II- Dados sobre a pesquisa cientí fica}

Título do protocolo de pesquisa: Estudo da expressão de genes homeobox em carcinoma epidermóide de boca

Pesquisador: Marcos Roberto Tavares

Cargo: médico assistente

Avaliação do risco da pesquisa

Sem risco( )

Risco baixo( $X)$

Risco mí nimo( )

Duração da pesquisa: 1 ano

III- Informações especí ficas sobre esta pesquisa e registro de informações e garantias do sujeito da pesquisa.

Recebi as seguintes informações:
Risco maior( )

Risco Medio 
A Disciplina de Cirurgia de Cabeça e Pescoço do Hospital das Clínicas de São Paulo está tentando conhecer melhor os processos genéticos que desenvolvem o câncer de boca, pra isso necessitamos de um pequeno pedaço de tumor $1 \mathrm{~cm} 3$, removido após cirurgia para não atrapalhar o estudo de margens, o fragmento será removido do centro do tumor. Sua participação é voluntária, portanto não há nenhum pagamento ou indenização.

Os resultados dos exames serão mantidos em segredo e só você e seu médico saberão seus conteúdos.

Caso o Sr(a) tenha alguma dúvida procure o médico responsável por esta pesquisa no telefone do medico ou dentista.

Autorizo coleta destes materiais para pesquisa

IV- Informações do responsável pela pesquisa para contato em casos de intercorrências clí nicas e reações adversas.

Seu nome: Marcos Roberto Tavares

Seu telefone: 30696425

\section{V- Consentimento pó s- esclarecimento}

Estou recebendo uma via do termo de consentimento pos-informação e entendi o seu conteúdo conforme nesta pagina e no seu verso. Dou autorização para divulgação dos dados obtidos de pesquisa sem que eu seja identificado e de acordo com a legislação vigente. Sei que posso desistir de participar desta pesquisa a qualquer momento, sem que por isto meu tratamento venha a ser prejudicado.

Declaro que, após convenientemente esclarecido pelo pesquisador ter entendido o que me foi explicado, consinto em participar do presente protocolo de pesquisa.

São Paulo,

Assinatura do sujeito da pesquisa (nome Legí vel)
Assinatura do pesquisador

(nome legí vel ou carimbo) 


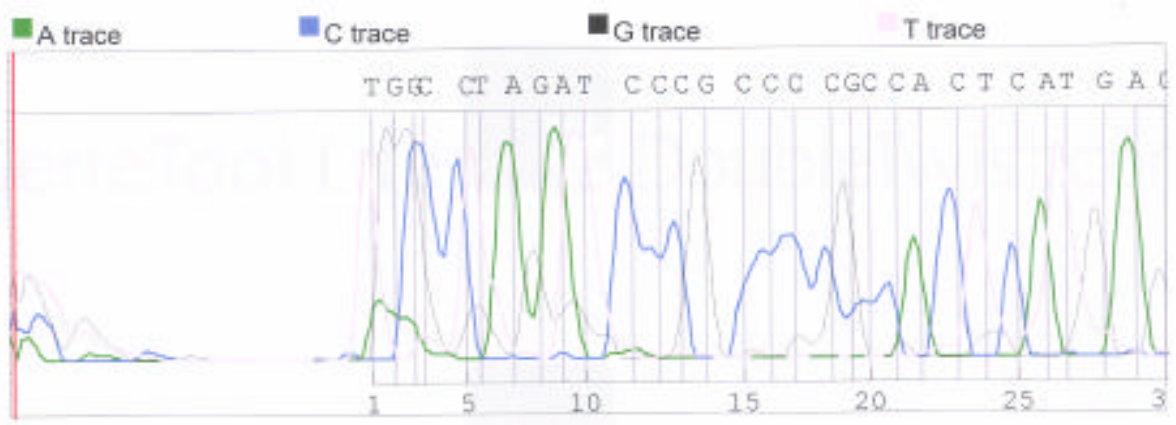

$-1$. 


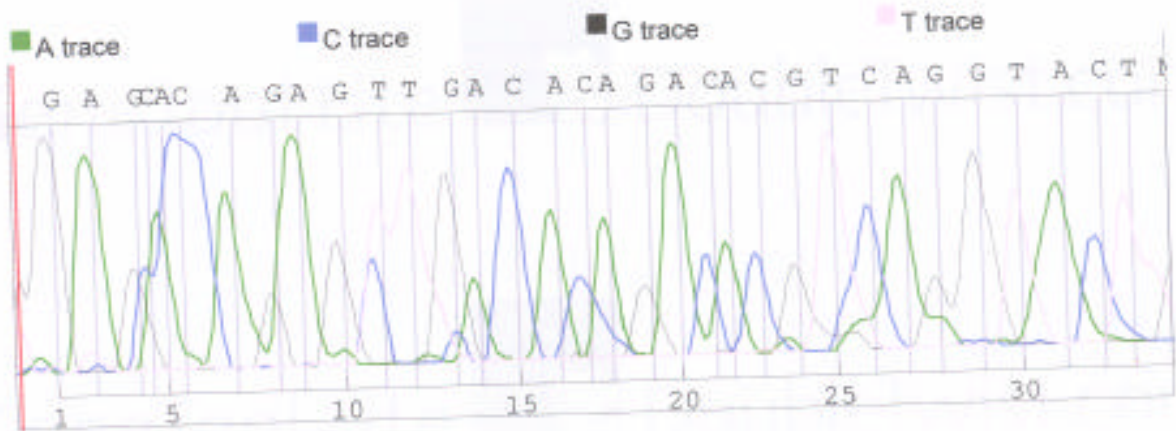




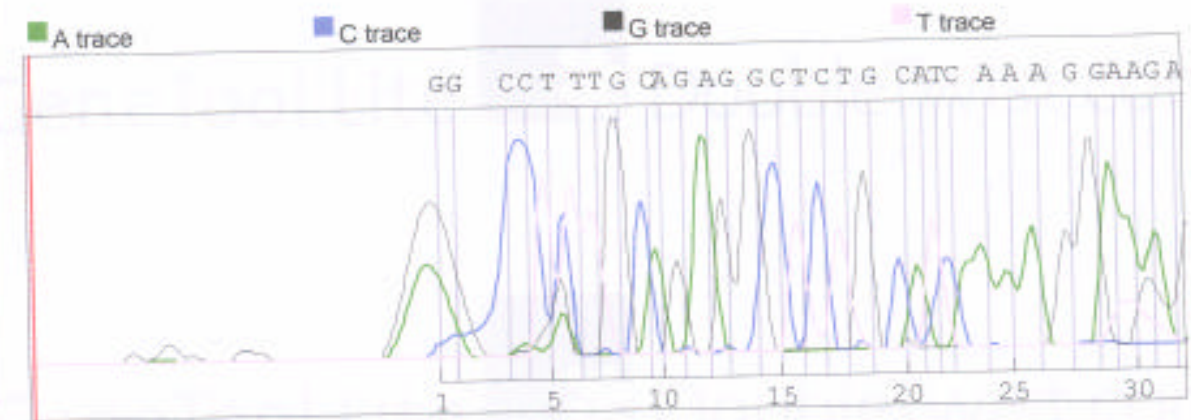

$-1$. 


W A trace
E trace

$-1$. 


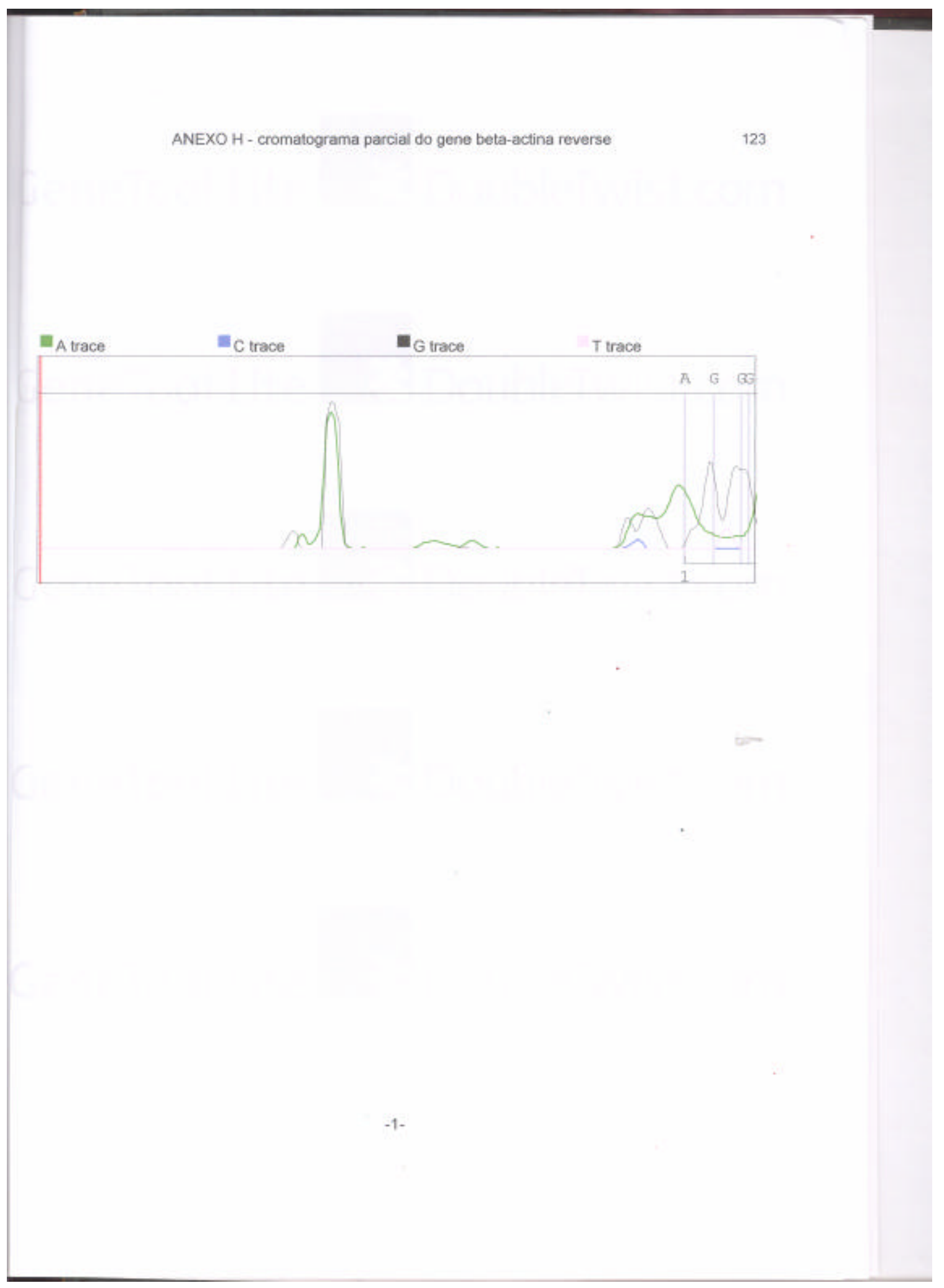

